\title{
EVALUATION OF PUMPAGE DATA FURNISHED BY SELECTED PUBLIC WATER SUPPLIERS IN \\ ARKANSAS, MAY 1990 THROUGH MARCH 1991
}

by Terrance W. Holland and Nancy T. Baker

U.S. GEOLOGICAL SURVEY

Water-Resources Investigations Report 93-4104

Prepared in cooperation with the

ARKANSAS SOIL AND WATER CONSERVATION COMMISSION

Little Rock, Arkansas

1993 
U.S. DEPARTMENT OF THE INTERIOR

BRUCE BABBITT, Secretary

U.S. GEOLOGICAL SURVEY

Dallas L. Peck, Director

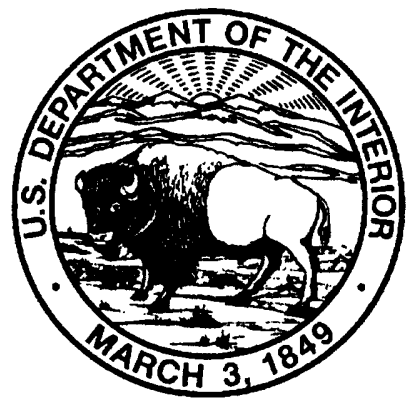

For additional information write to:

District Chief

U.S. Geological Survey, WRD 2301 Federal Office Building Little Rock, AR 72201
Copies of this report can be purchased from:

U.S. Geological Survey

Books and Open-File Reports Section

Federal Center

Box 25425

Denver, CO 80225 


\section{CONTENTS}

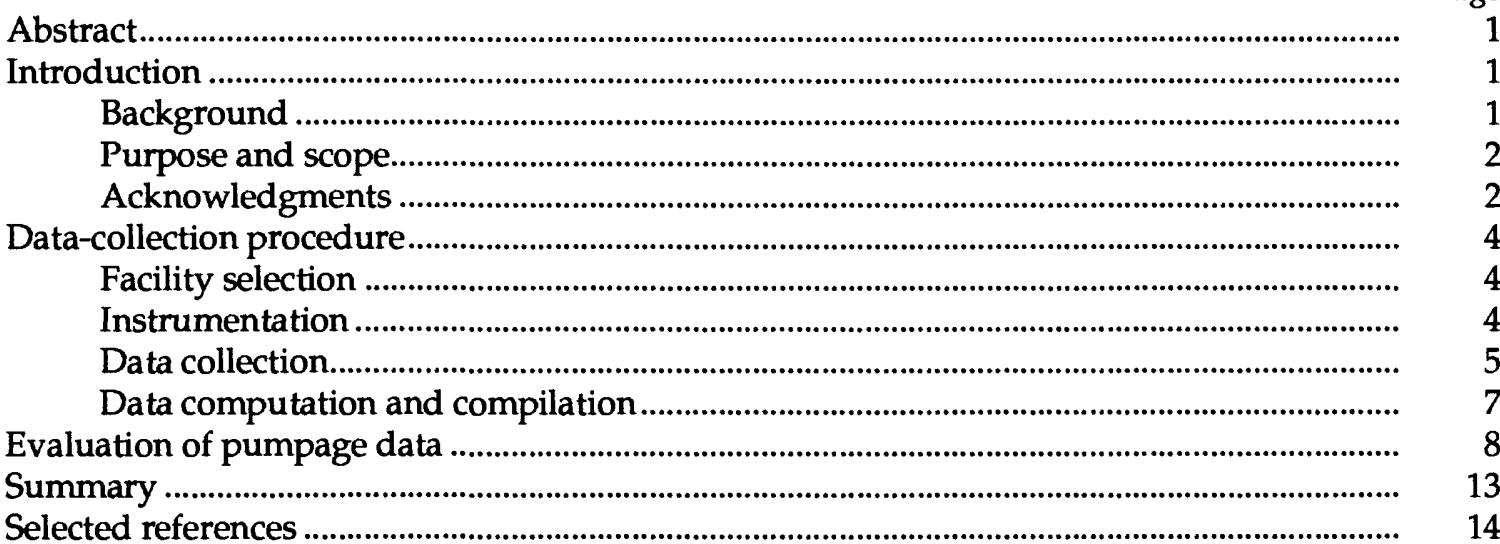

\section{ILLUSTRATIONS}

Figure 1. Map showing location of public water supplies selected for this study.

2-6. Graphs showing:

2. Relation of noninvasive flow measurement by (A) a time of flight type flowmeter, and (B) a reflective doppler type flowmeter to inline measurement.

3. Percent difference between pumpage measured by noninvasive flowmeter and pumpage reported to the Arkansas Soil and Water Conservation Commission.

4. Percent difference between pumpage measured by noninvasive flowmeter and pumpage reported to the Arkansas Department of Health

5. Percent difference between pumpage measured by noninvasive flowmeter and pumpage measured by inline flowmeter.

6. Absolute average percent difference between pumpage measured by noninvasive flowmeter and withdrawals (A) reported to the Arkansas Soil and Water Conservation Commission, (B) reported to the Arkansas Department of Health, and $(\mathrm{C})$ measured by inline flowmeter for facilities serving population less than 500, between 500-900, between $901-3,000$, and more than 3,000 .

TABLES

Table 1. Description of selected public water-supply facilities in Arkansas and flowmeasurement conditions at these sites, 1990.

2. Water withdrawals computed from noninvasive flowmeter measurements, reported to State agencies, and computed from inline flowmeter measurements.

3. Flow data collected from public water-supply systems in Arkansas where record of pump running time was obtained from log books kept by the plant operator.

4. Flow data collected from public water-supply systems in Arkansas where record of pump running time was determined from either electric energy consumption or vibration time totalizer.

5. Pipeflow measurements made at public-supply facilities in Arkansas by noninvasive and inline flowmeter and natural log-percent difference. 


\section{TABLES (continued)}

6. Absolute average percent differences between water use measured by non-

Page invasive flowmeter and that reported to the Arkansas Soil and Water Conservation Commission (ASWCC), the Arkansas Department of Health (ADH), and measured by inline flowmeter for facilities serving population less than $500,500-900,901-3,000$, and more than 3,000

7. Percent difference between water use reported to the Arkansas Soil and Water Conservation Commission (ASWCC) and measured by inline flowmeter ...........

8. Percent difference between water use reported to the Arkansas Soil and Water Conservation Commission (ASWCC) and the Arkansas Department of Health (ADH)

\section{CONVERSION FACTORS}

Multiply

inch (in.)

mile (mi)

gallon (gal)

gallon per minute (gal $/ \mathrm{min}$ )

gallon per day (gal/d)

million gallons per day (Mgal/d)

acre-foot (acre-ft)
By

2.54

1.609

3.785

0.06308

0.003785

0.04381

1,233
To obtain

millimeter

kilometer

liter

liter per second

cubic meter per day

cubic meter per second

cubic meter 


\title{
EVALUATION OF PUMPAGE DATA FURNISHED BY SELECTED
}

\author{
PUBLIC WATER SUPPLIERS IN ARKANSAS,
}

\author{
MAY 1990 THROUGH MARCH 1991
}

\author{
By Terrance W. Holland and Nancy T. Baker
}

\begin{abstract}
Comparisons between water pumpage calculated from noninvasive pipeflow measurements and pump running times, and pumpage reported to the Arkansas Soil and Water Conservation Commission (ASWCC) and the Arkansas Department of Health reveal variation between measured and reported data. Less variation exists between pumpage calculated from noninvasive pipeflow measurements and amounts calculated from inline measurements. Variation in reporting accuracy among water-supply facilities is to be expected. Each facility has a different level of capability to determine the amount of water it withdraws. However, at some facilities that are equipped with inline flowmeters there are significant differences between measured and reported pumpage. The average percent difference between pumpage measured by noninvasive flowmeter and that reported to the ASWCC is about 26 percent.

Variation between measured and reported pumpage ranged from -253.6 percent to 85.4 percent. Variation between pumpage measured by noninvasive flowmeter and inline flowmeter ranged from -125.4 percent to 90.2 percent. Overall there was significantly less variation between pumpage measured by noninvasive and inline meters.

Percent differences between pumpage measured by noninvasive flowmeter and reported to the ASWCC were the smallest for facilities serving fewer than 500 people, and largest for facilities serving between $500-900$ people. Percent differences between pumpage measured by noninvasive flowmeter and reported by facilities were lower for those facilities that reported to both agencies than for those facilities that reported only to the ASWCC.
\end{abstract}

\section{INTRODUCTION}

Site-specific public-supply data are available for most states where permits are required or where water-use reporting is mandatory. However, little is known about the accuracy of the reported data and few studies have assessed the accuracy of water-use information reported by individual public-supply facilities. As competition for water resources increases, so does the demand for accurate water-use information. Accurate and reliable public-supply data are essential for defining existing problems and anticipating future water needs. Because the accuracy of these data are not known, the Arkansas Soil and Water Conservation Commission (ASWCC) and the U.S. Geological Survey (USGS) are working cooperatively to evaluate water-use information reported by public suppliers.

\section{Backaround}

Public-supplied water includes water withdrawn by public or private water suppliers and delivered to groups of users. Public suppliers provide water for a variety of uses, such as domestic, commercial, thermoelectric power, industrial, and public water use (Solley and others, 1988, p. 10). Public supply also is referred to as municipal water supply, public water supply, or water supply. 
In Arkansas, public-supply facilities are required to obtain a permit from the Arkansas Department of Health $(\mathrm{ADH})$, and to report the amount of water used to the ASWCC. In accordance with the public Drinking Water Regulations, enacted in the early 1930's (H. Seifert, Arkansas Department of Health, oral commun., 1992), the ADH require reporting of municipal water use. According to ADH, a municipal supplier must serve either 15 people annually or 25 people 60 days per year. Monthly municipal water-use reports include daily pumpage, chemical treatment, type of treatment, population served, and other information. These data are used by $\mathrm{ADH}$ for several purposes: monitoring chemical treatment of municipal waters, evaluation of consumption rates, and notification of facilities when they withdraw water in excess of 80 percent of the plant's peak capacity.

Arkansas Act 180 of 1969 requires the diversions of water from streams, lakes, and ponds (except natural lakes owned by individuals) to be reported annually to ASWCC. This report must include the amount, the purpose, and the location of the use. The purpose of reporting surface-water diversions is to provide data to the ASWCC for water- resources planning and management. Act 1051 of 1985, as amended by Act 460 of 1987, requires the reporting of all water withdrawals of ground water, except water withdrawals exclusively for domestic use or from wells that have a potential yield of less than 50,000 gallons per day. The ASWCC uses this information inconjunction with the surface-water diversion data to determine the requirements of all water users of the State. These data also are evaluated in the State Water Plan to project future water needs.

During 1989, 697 Arkansas water-supply facilities were listed in the U.S. Geological Survey SiteSpecific Water Use Data System (SSWUDS) (Baker and others, 1991). Of those facilities, 507 withdrew their water from a ground- or surface-water source (the other 190 facilities purchase their water). Of the 507 facilities, 435 withdraw from ground-water sources and 72 withdraw from surface-water sources. Facilities withdrawing from ground-water sources serve a population of 0.9 million, while those withdrawing from surface-water sources serve about 1.1 million (Baker and others, 1991).

In 1990, a study was begun by the USGS, in cooperation with the Arkansas Soil and Water Conservation Commission, to assess the accuracy of these reported pumpage data. The objective of the study was to evaluate the accuracy of reported water-use data. This information will be used to refine water-resources planning and management needs.

\section{Purpose and Scope}

This report describes an analysis of the accuracy of pumpage data reported by selected public and private water suppliers in Arkansas. Water withdrawals reported to ASWCC and ADH are compared with calculated withdrawals using two types of noninvasive flowmeters and pump operation times. Other analyses included comparisons of (1) data from noninvasive flowmeters with data from inline flowmeters, (2) data reported to ASWCC with data reported to $\mathrm{ADH}$, and (3) data by population group.

The study area includes the entire State of Arkansas (fig. 1). Data were collected during 1990-91 for 41 selected facilities that met criteria for selection as a study site. Selected study sites represented about 10 percent of the facilities that meet the selection criteria.

\section{Acknowledoments}

The authors express appreciation to personnel associated with those public supply facilities that participated in the study. Appreciation is also extended to Mr. Harold Seifert, Director, Division of Engineering, Arkansas Department of Health, for providing water-withdrawal information for those public suppliers that reported water withdrawals to the $\mathrm{ADH}$, and to the Arkansas Soil and Water Conservation Commission for providing water withdrawal information for those public suppliers that reported to the ASWCC. Appreciation is extended to Dr. Kenneth F. Steele, Director, Arkansas Water Resources Research Center, and Dr. James Dunn and Dr. Ronald McNew of the Agricultural Statistics Laboratory, University of Arkansas, for reviewing the project proposal and making suggestions for determining sampling population. 


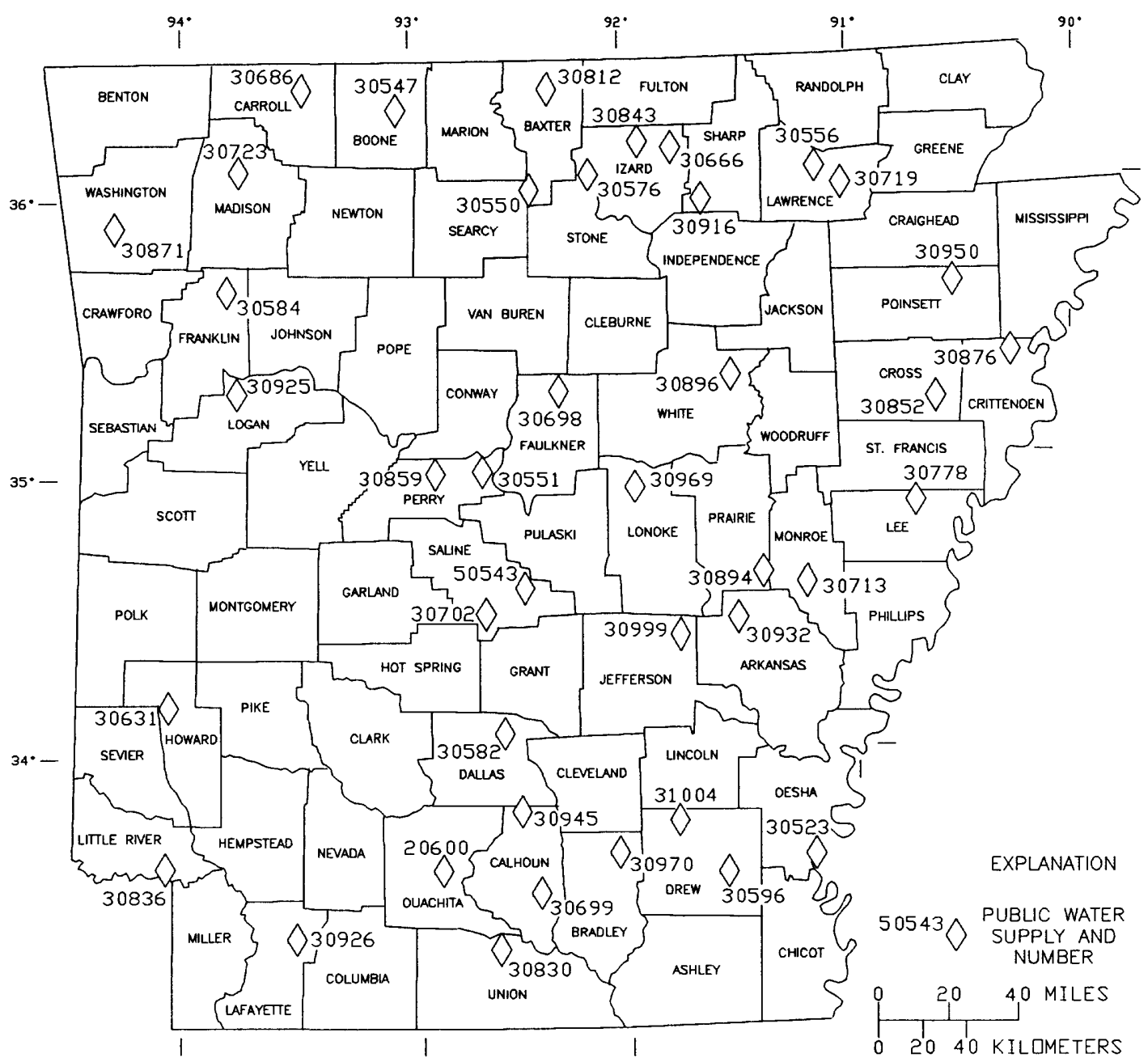

Figure 1.--Location of Arkansas public water supplies selected for this study. 


\section{DATA-COLLECTION PROCEDURE}

The absolute accuracy of measured or reported pumpage data is difficult to assess. All methods of measuring total water withdrawals require either obtaining an instantaneous pipeflow measurement and a measure of pump running times during the period of interest, or using an accumulative flowmeter, which records each gallon of water that passes the meter. If an instantaneous flow measurement is made, flow rates must not fluctuate substantially during the period of interest for an accurate estimate of total water withdrawals to be obtained. Even when an accumulative inline flowmeter is available, it is difficult to know the condition of the flowmeter. Mineral buildup or corrosion on the meter can decrease its accuracy.

It is significantly more difficult to assess the accuracy of reported pumpage data. Reported data are often derived from various sources, and each facility may use a different procedure to obtain water-use volumes. Some facilities calculate monthly water withdrawals from inline flowmeter readings. Others estimate water withdrawals based upon the amount of water sold to customers. Some facilities multiply an average daily volume by the number of customers served by that facility. Many facilities estimate a total annual withdrawal and divide by 12 to obtain monthly water withdrawals.

Measured and reported pumpage data were collected between May 1990 and March 1991 for 41 selected public-supply facilities. A few facilities required additional site visits to obtain the required number of measurements. Instantaneous pipe-flow measurements (using a noninvasive flowmeter) were made and pump operation times were recorded monthly at most of the sites. Measured data were compiled and monthly water-use volumes were computed for comparison with monthly reported data.

\section{Eacility Selection}

Of the 507 facilities cited above, 423 facilities met criteria for selection as a potential study site. These criteria included: (1) the facility furnishes water to at least 25 people, (2) the facility must have a minimum of 15 hookups, and (3) the facility must withdraw the majority of the water used by the population, rather than purchase the majority of water used (some facilities withdraw water only as a backup to purchased water).

Approximately 10 percent of the 423 facilities were selected for the investigation. Potential sites were selected by first arranging the 423 facilities into four groups based on the population served by each facility. Population ranges for each group include facilities serving (1) fewer than 500 people, (2) between 500 and 900 people, (3) between 901 and 3,000 people, and (4) more than 3,000 people. Initially 11 facilities were selected randomly from each population group. Through the course of the investigation three facilities were eliminated from the study. Additional facilities were not added because of the brief time frame available for data collection and because, even with the loss of three facilities, an approximate 10 percent sample was maintained. Only one of the facilities included in the investigation reported water withdrawals to neither the ASWCC nor the ADH.

\section{Instrumentation}

Pipeflow measurements were made with portable, noninvasive pipe flowmeters. Two types of meters were used during the course of the investigation-the Cross Correlation flowmeter and the Polysonics flowmeter ${ }^{1}$. The measurement situation at each particular site determined the type of meter used. In most cases, the same type of meter was used for each site throughout the investigation.

${ }^{1}$ Use of trade names in this report is for identification purposes only and does not constitute endorsement by the U.S. Geological Survey. 
The Cross Correlation flowmeter is a "time-of-flight" instrument that measures the time it takes a fluid to move from one position in the pipe to a second position downstream (E.H. Cordes, U.S. Geological Survey, written commun., 1989). The Cross Correlation flowmeter works well in situations where disturbances occur in the flow (generally caused by an elbow, pipe seam, or flange, or where flow velocities are rapid enough to create turbulence).

The Polysonics flowmeter is a reflective-doppler type flowmeter that uses a continuous, ultrasonic signal transmitted from a stationary transducer to a particle in the stream (in some cases an air bubble). A receiving transducer detects the frequency shifts of the reflected signal. The frequency shifts are then processed to determine the velocity of the fluid (Arvin, 1992). The Polysonics flowmeter works best for flows that contain some particulate matter (as in untreated water).

Although it is difficult to assess the accuracy of measured data, success has been reported by Arvin (1992) in the performance of two types of noninvasive flowmeters for measuring flow in closed systems. A noninvasive flowmeter is an instrument that can measure the flow of a fluid through a pipe without having to come in direct contact with the fluid. Arvin found that the "time-of-flight" type flowmeter had a mean log-percent difference from inline measurements of 7.5 and a standard deviation of 3.7. The reflective-doppler type meter had a mean log-percent difference from inline measurements of -14 and a standard deviation of 18 . Noninvasive flow measurements made by a time-of-flight type flowmeter and the Hydra flowmeter (a reflective-doppler type flowmeter) are related to inline flow measurements in figure 2. Measurements made with the noninvasive flowmeters provide data to which reported data from one or more sources can be compared.

Following the reconnaissance visits, data were collected approximately every month until at least six valid measurements were obtained at each facility. During the site visit, noninvasive pipeflow measurements were made to obtain an instantaneous flow for each primary withdrawal site. Accumulative pump operation times were recorded, and inline pipeflow measurements were recorded for those sites where these flowmeters were available. The ability to collect the required number of measurements was affected by variable conditions at each facility. These conditions include (1) the layout of the flow distribution system, (2) the water storage capacity of the facility (which determines the frequency of pump operation), and (3) the availability of plant personnel. Variability in any of these conditions limits the ability to make a flow measurement at the facility during the monthly site visit.

\section{Data Collection}

Reconnaissance visits were made to each public-supply facility selected for the investigation to: (1) obtain permission from the water superintendent to collect the necessary data, (2) gain access to the well or intake structure, (3) evaluate the measuring conditions at each site, (4) locate the electric meter associated with each pumping plant or determine a suitable location for installation of time totalizers (instruments to measure pump running times), and (5) document pertinent information about the pump and electric meter.

Accumulative pump running times were obtained from the electric meter associated with a particular pumping plant, vibration time totalizer, or from log books maintained by the plant operator. Most of the pumping plants in the study have an individual electric watt-hour meter connected to the pump. The watt-hour meter records the energy consumption of the pump. Pumping times were calculated by the following equation (Hurr and Litke, 1989):

$$
\mathrm{t} \text { (hours) }=\text { energy (kilowatt hours)/power (kilowatts) }
$$

To apply this equation, energy consumption (recorded from watt-hour meters) and power demand (the rate of energy consumption) were determined and recorded. Vibration time totalizers were placed on pumps where watt-hour meters were connected to more than one pump or to lights, chlorinators, and outlets. The vibration time totalizer is activated by the vibration of the pump and keeps a cumulative total of pump operation time. Many plant operators keep a chronological log of pump operations by recording each time the pump is turned on and off. If the plant operator kept a log book, entries were recorded during the site visit. 


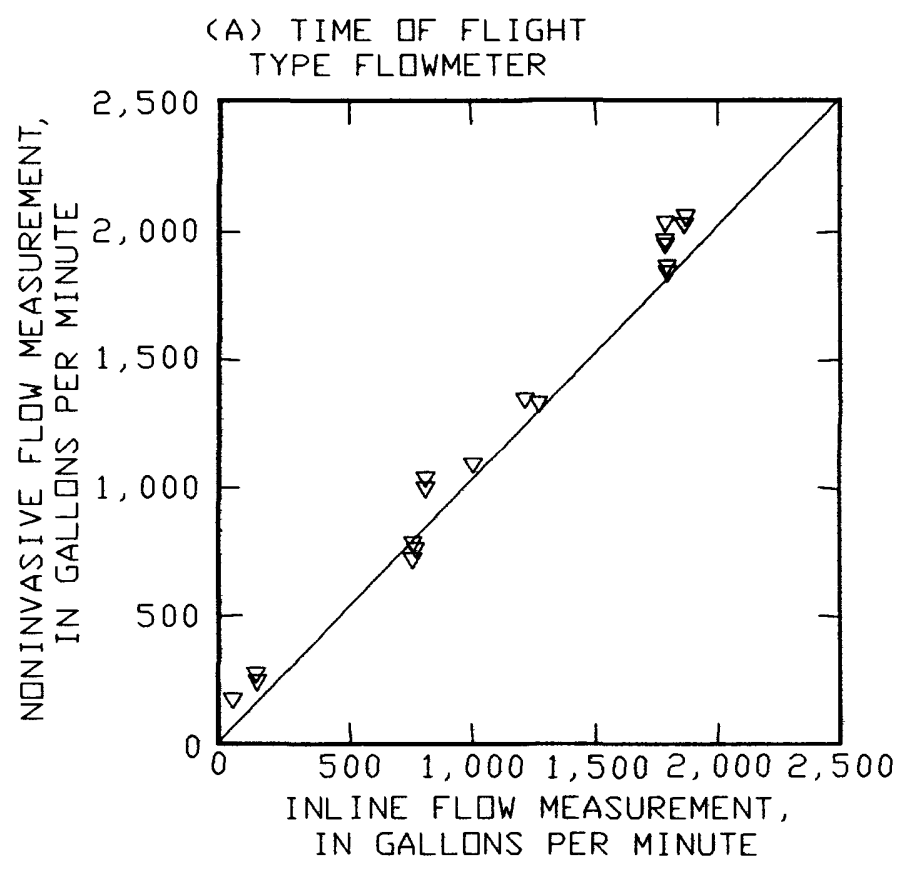

(B) REFLECTIVE DOPPLER TYPE FLDWMETER

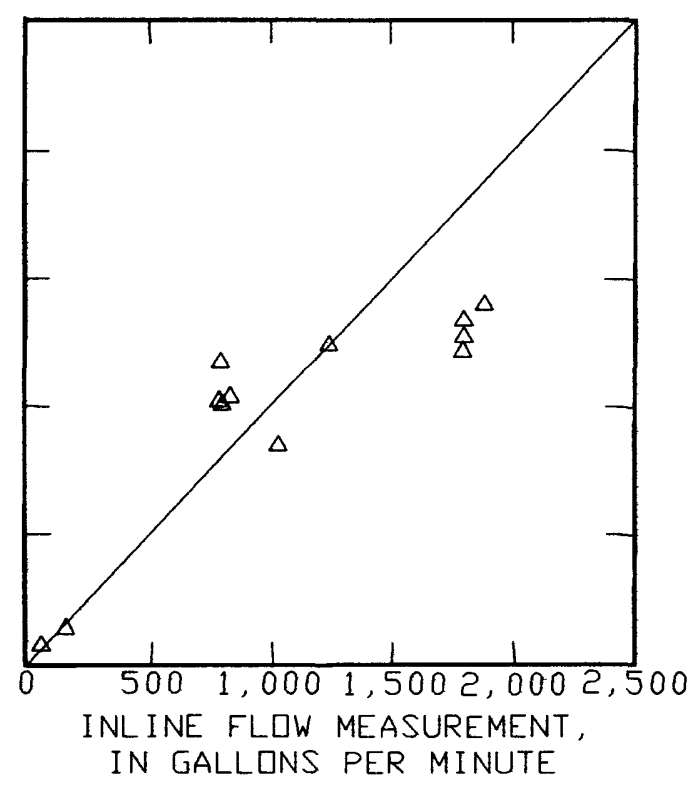

Figure 2.--Relation of noninvasive flow measurement by (A) a time of flight type flowmeter, and (B) a reflective doppler type flowmeter to inline measurement.

Source: Arvin, 1992. 
A general description of each measurement site and some of the ancillary data collected are provided in table 1 at the end of the report. In this table, an evaluation of the measuring conditions at each site is given in the "Measurement condition rating" in terms of good, fair, or poor. Sites were classified as having good measuring conditions based on the availability of a sufficient length of unrestricted pipe to make flow measurements. Sites rated fair or poor are described in greater detail with respect to measurement problems in the "Comments" section. At most sites, the reflective-doppler type flowmeter was used because of limited lengths of unrestricted pipeflow due to presence of cutoff valves, elbows, or venturi. But at sites where acceptable lengths of discharge pipe were available, where there were extremely high flow rates, or there were multiple pumps feeding a common discharge pipe, the crosscorrelation flowmeter was used.

\section{Data Computation and Compilation}

Data collected during the site visits to each facility were compiled and monthly water-use volumes were computed for comparison with monthly data reported to the ASWCC and ADH. Calculated and reported water-withdrawal data are summarized in table 2 at end of report. Water withdrawals are usually reported by public water-supply facilities to the ASWCC and ADH as monthly values for each month. It should be noted that some facilities group withdrawal data for more than one well (for example Yorktown, wells 1 and 2, table 2) prior to reporting to ASWCC or ADH.

Data significant to the dates of the measurements for both water withdrawal readings (noninvasive and inline), and the period of record represented are presented at the end of the report in tables 3 and 4. Therefore, hourly pumping rates can not be transposed to table 2, which represents total number of hours pumped per calendar month for the period of record. Although data were collected approximately every month at each of the sites, they were not collected at precisely 30- or 31-day intervals, nor were data collected on the same day in every month. However, monthly pump running times were needed, along with instantaneous flow measurements, to compute monthly water-use volumes that were comparable with the monthly data reported to the ASWCC and ADH. At those facilities where pump running times were recorded only from electric watt-hour meters or vibration time totalizers, the values were summarized to whole monthly values. Adjustments to pump running times (column 2, table 2) were made by determining the pumping rate (in hours per day) for each measurement period (table 4) and multiplying it by the number of days in each month for which that rate applied. For example, to determine the adjusted monthly pump running time at Arkansas City for July 1990 using table 4:

$$
\begin{aligned}
& \text { July 1-24 }=24 \text { days } \\
& \qquad \begin{array}{r}
24 \text { days } \times 10.1 \text { hours } / \text { day }=242.4 \text { hours pump running time } \\
\text { July } 24-31=7 \text { days } \\
\quad 7 \text { days } \times 4.7 \text { hours } / \text { day }=32.9 \text { hours pump running time }
\end{array} \\
& \text { Adjusted monthly pump running time }=275 \text { hours (rounded) }
\end{aligned}
$$

For those facilities that used chronological log records to determine the number of hours pumped per month (table 3), the pump running times were extracted directly from these records and computed for each calendar month (table 2). Where monthly pump running times were available from chronological logs maintained by the plant operator, these data were preferentially used whenever possible to compute water withdrawals, even when electric watt-hour meter and vibration time totalizer data were available.

Pipeflow measurements at most sites did not fluctuate substantially from one measurement to the next. However, minor fluctuations, due to local conditions at the time of measurement, did occur at all sites. For this reason, instantaneous pipeflow measurements collected during the investigation were averaged (tables 3 and 4 ) for each site before water-withdrawal amounts were calculated (table 2). 


\section{EVALUATION OF PUMPAGE DATA}

Withdrawals calculated from noninvasive pipeflow measurements and pump running times were compared to monthly pumpage reported to the ASWCC and ADH in order to evaluate the accuracy of the reported data. Inline pipeflow measurements were compared to the noninvasive pipeflow measurements and reported data for those sites where inline flowmeters were present. Comparisons were made by grouping the results by population range, and the presence of inline flowmeters at these facilities. Comparisons were also made between water withdrawals reported to the ASWCC and those amounts reported to the ADH, and between water withdrawals reported to the ASWCC and the amounts measured by inline flowmeter.

The percent difference between the monthly noninvasive flowmeter measurements and monthly water withdrawals reported to the ASWCC ranged from -151.4 to 85.4. The percent difference between the monthly noninvasive flowmeter measurements and monthly water withdrawals reported to the ADH ranged from -253.6 to 61.7 . The percent difference between the monthly noninvasive flowmeter measurement and the monthly inline flowmeter measurement ranged from -125.4 to 90.2 (table 2). The distributions of the percent differences show that there is significant variation between withdrawals measured by noninvasive flowmeter and withdrawals reported to the ASWCC or to the ADH (figs. 3 and 4). Although the reported pumpages of some facilities (Bennett Acres, 30543) were consistently higher than measured amounts and the reported pumpages of some facilities (Arkansas City Waterworks, 30523) were consistently lower than measured pumpages, most of the facilities reported a wide range of pumpage compared to the measured usage. Somewhat less variation in percent differences occurred between water withdrawals measured by noninvasive flowmeter and measured by inline flowmeter (fig. 5). Comparisons of noninvasive pipe-flow measurements and inline pipeflow measurements indicate that for most sites the two measurements were similar (table 5 at end of report) and within the ranges reported by Arvin (1992) for the noninvasive pipeflow meters that were tested against inline flowmeters.

The absolute average percent difference between pumpage measured by noninvasive flowmeter and pumpages reported to the ASWCC ranges from 2.4 to 83.7 with an overall average of 25.4 percent. The range between the noninvasive measurement and that reported to the ADH was from 2.5 to 49.4 with an overall average of 18.8. For those facilities that report to both the ASWCC and ADH the average absolute percent difference between pumpage measured onsite by noninvasive flowmeter and amounts reported to the ASWCC was 21.3 percent. For those same facilities the average absolute percent difference between pumpage measured onsite by noninvasive flowmeter and amounts reported to the ADH was 20.3 percent. For those facilities that reported only to the ASWCC the average absolute percent difference between pumpage measured onsite by noninvasive flowmeter and amounts reported was 29.9 percent. The comparison of water withdrawals measured by noninvasive and inline flowmeters ranged from 2.0 to 46.4 with an overall average of 15.2 (table 6 at end of report).

When the absolute average percent difference for each site is arranged by population group, the results show that facilities serving fewer than 500 people reported withdrawals to the ASWCC and to the $\mathrm{ADH}$ that were closer to withdrawals measured by noninvasive flowmeter than did facilities serving more than 500 people (fig. $6 \mathrm{~A}$ and $6 \mathrm{~B}$ ). The absolute average percent difference between withdrawals measured by noninvasive flowmeter and inline flowmeter was significantly lower for facilities serving more than 900 people than for facilities serving fewer than 900 people (fig. 6C). The largest absolute average percent difference (32.9) was between withdrawals measured by noninvasive flow and those reported to the ASWCC for facilities serving between 500-900 people (table 6). Facilities serving more than 3,000 people also had larger absolute average percent differences for both the "reported data" comparisons. It is difficult to determine the reasons for the variation between measured and reported water withdrawals for the different population groups. Perhaps it is easier to obtain an accurate measurement on water-supply systems that serve less than 500 people. Larger systems often have multiple wells or intakes and elaborate water-treatment equipment that can interfere with flow measurements and time totalizer devices. 


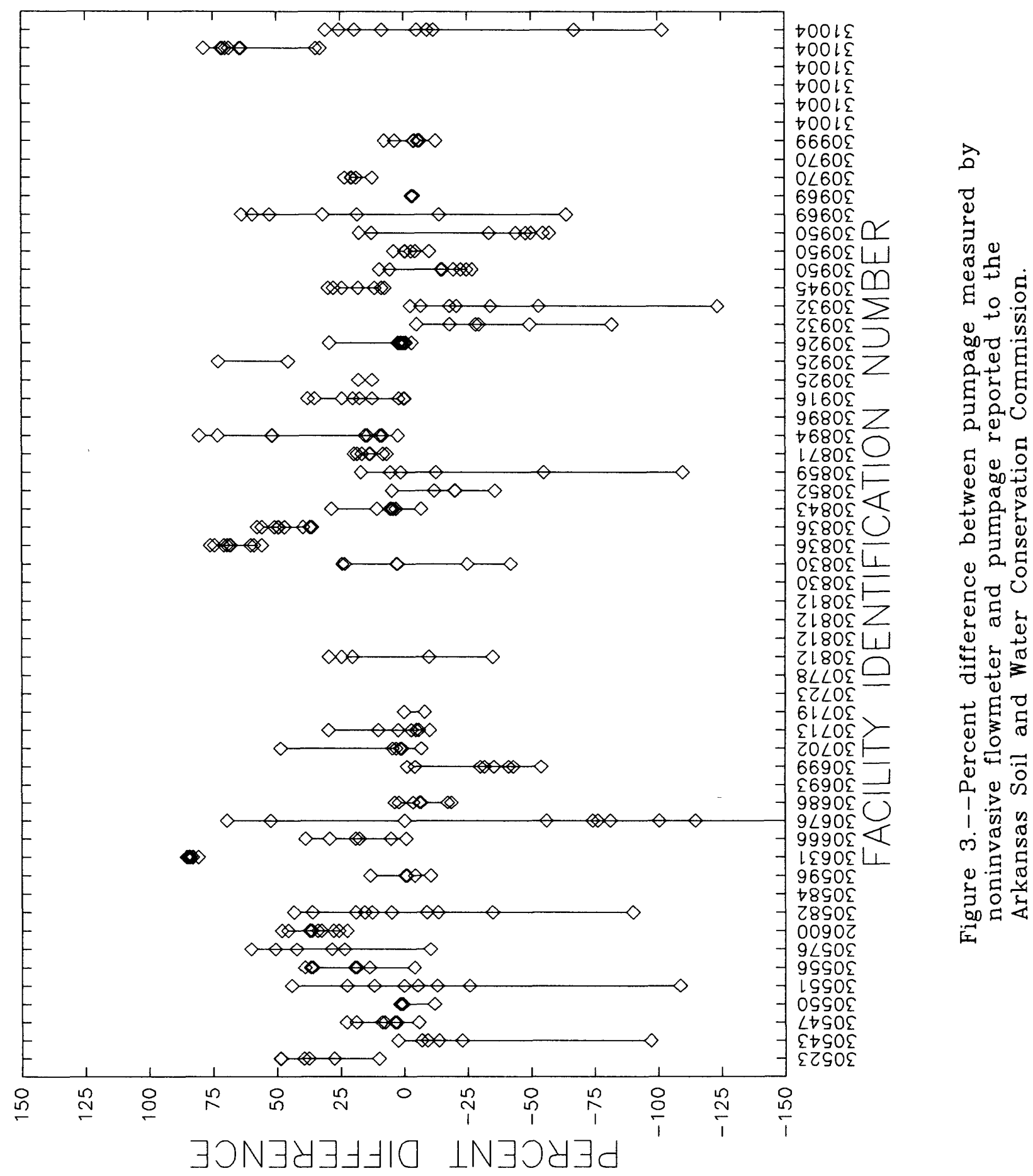




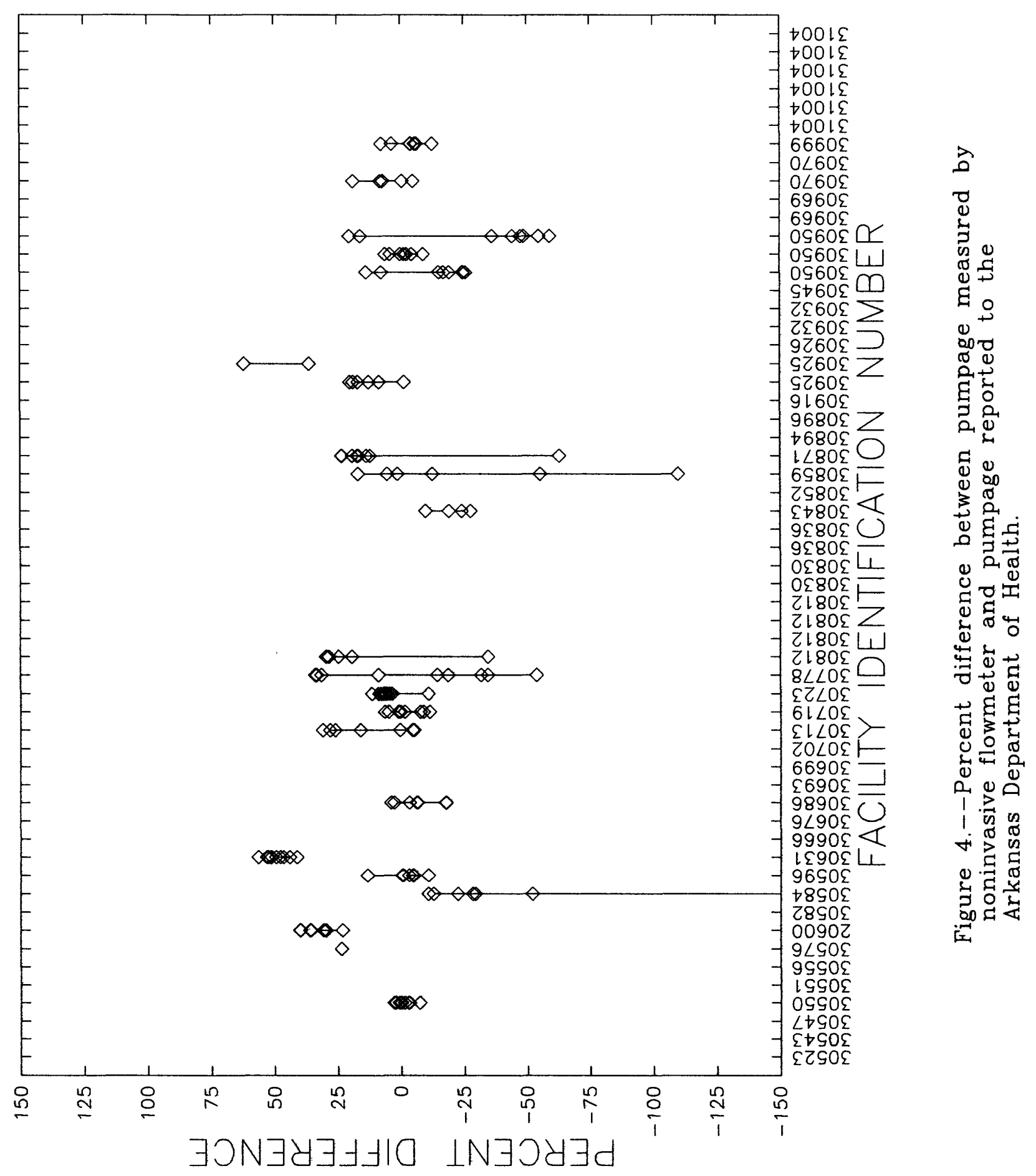




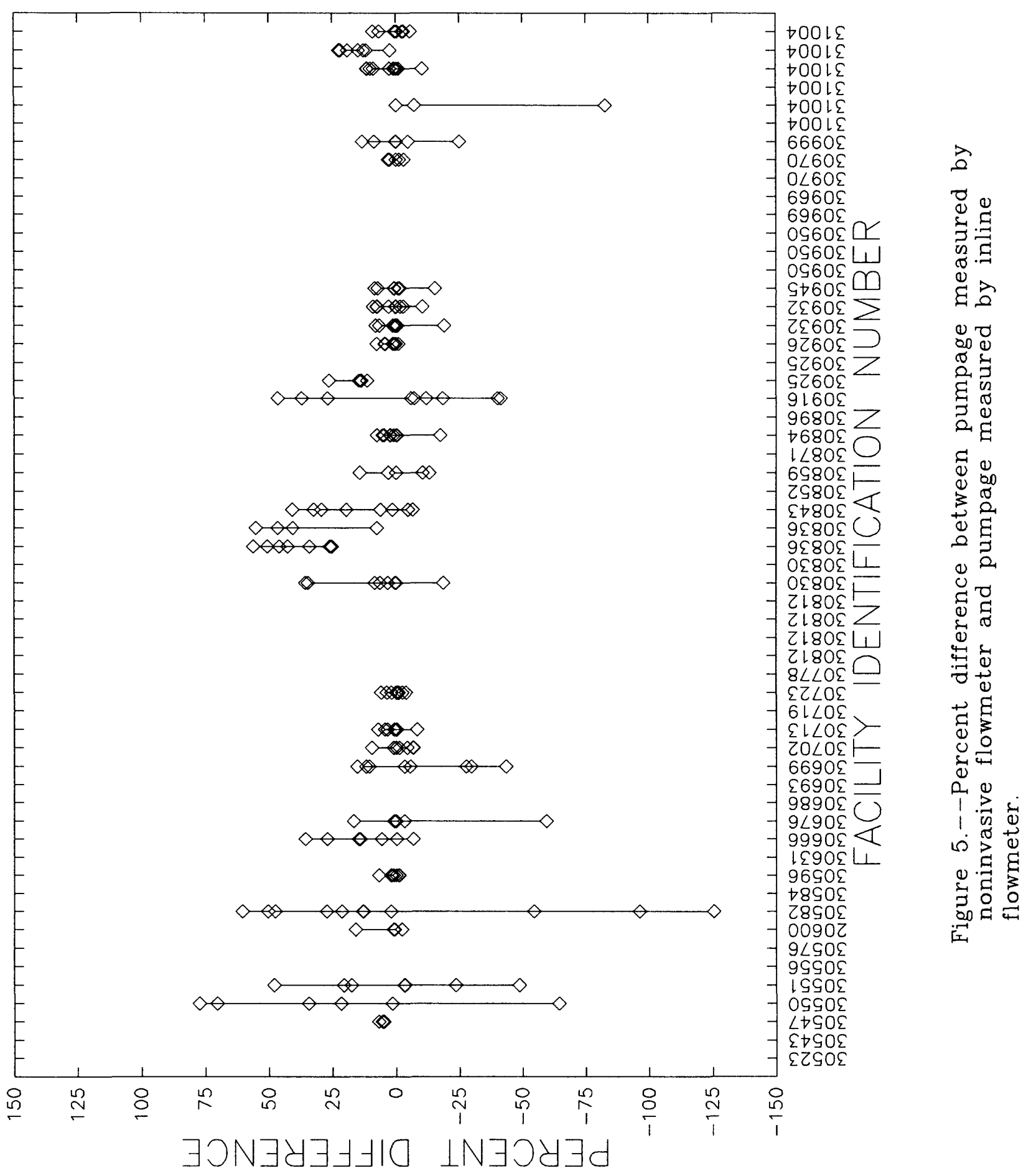




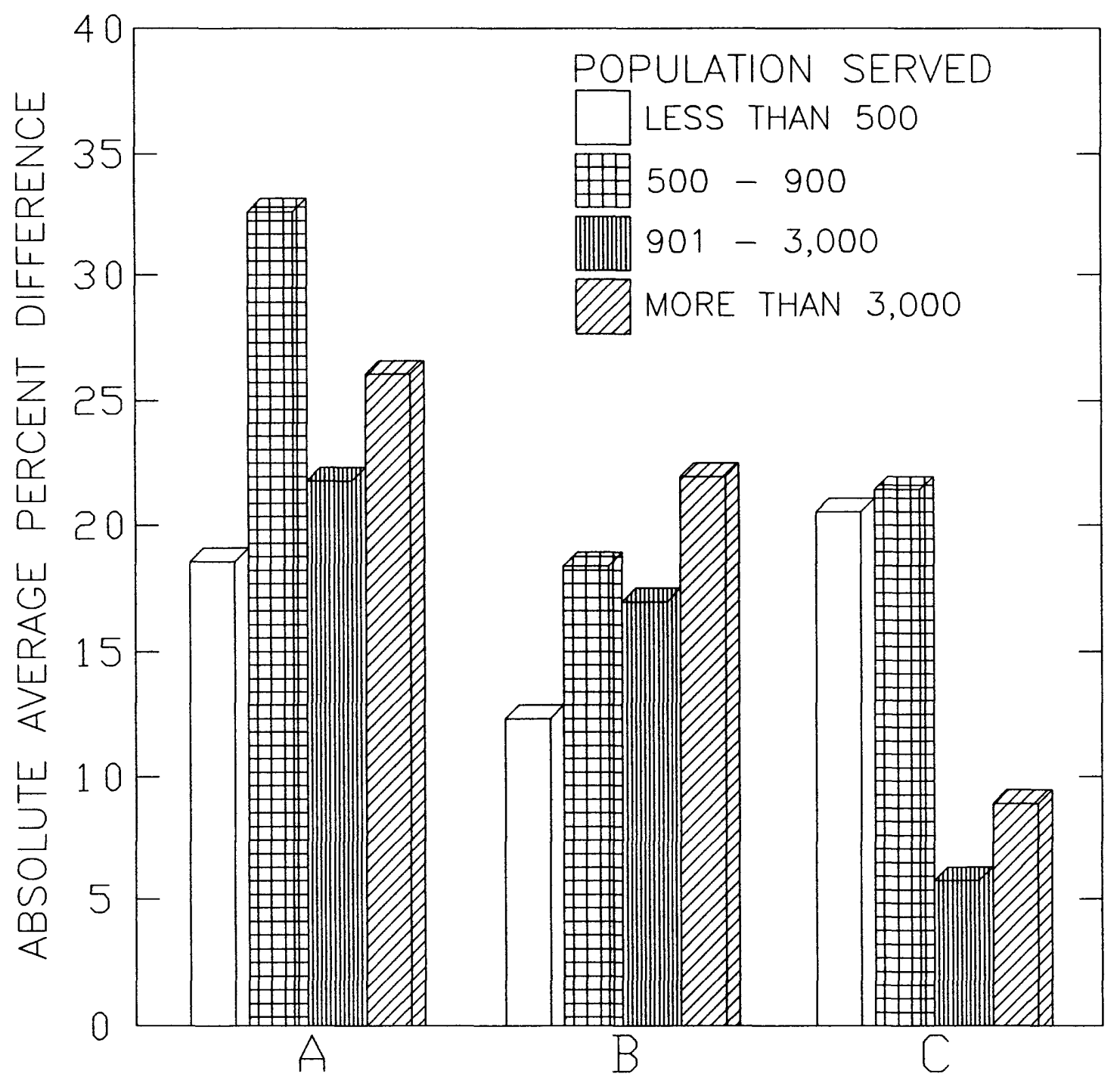

Figure 6.--Absolute average percent difference between pumpage measured by noninvasive flowmeter and withdrawals (A) reported to the Arkansas Soil and Water Conservation Commission, (B) reported to the Arkansas Department of Health, and (C) measured by inline flowmeter for facilities serving population less than 500, between 500 - 900, between $901-3,000$, and more than 3,000. 
Withdrawals reported to the ASWCC and withdrawals measured by inline flowmeter should be comparable. Facilities that used inline flowmeters to determine water use reported withdrawals within -4.4 of the measured values. Percent differences for this comparison ranged from -61.3 to 38.7 (table 7). In some instances, it is apparent (table 2) that an annual withdrawal values was divided by 12 months to arrive at a monthly value, even though an inline meter was present (Carthage, 30582; Harrell, 30699; Sidney, 30916; and Thornton, 30945).

Natural log percent difference comparisons also were made between withdrawals reported to the ASWCC and those reported to the ADH. This comparison shows that most of the facilities did report the same (or nearly the same) withdrawals to both agencies (table 8). The only sites that reported significantly different pumpages to the separate agencies were Dierks Waterworks (30631) and St. Paul Waterworks for their well 2 (30925). Discrepancies between withdrawals reported to the two agencies exist because of multiple conversions of the data reported to the ASWCC. Because the majority of data reported to the ASWCC are reported and stored in acre-feet, data collected by municipal suppliers (usually in gallons) are converted to acre-feet before storing to maintain consistency in the data base. Data retrieved from the data base were converted back to gallons for this investigation.

Some error may have been introduced when pumpage volumes were calculated from measured pipeflow (for both inline and noninvasive meters) for those sites where pump running times were obtained from electric meter or vibration time totalizer. These errors were created in some locations by other equipment within the pump house (such as chlorinators, fans, and heaters). These types of equipment operate during and many times beyond the period of time in which pumping occurs, thus distorting pump running times.

\section{SUMMARY}

Site-specific, public-supply data are available for most States where permits are required or where water-use reporting is mandatory. However, little is known about the accuracy of the reported data. Because the accuracy of these data are not known Arkansas Soil and Water Conservation Commission (ASWCC) and the U.S. Geological Survey (USGS) are working cooperatively to evaluate water-use information reported by public suppliers.

Measured and reported pumpage data were collected between May 1990 and March 1991 for 41 selected public-supply facilities in Arkansas. Instantaneous pipeflow measurements (using a noninvasive flowmeter) were made and pump operation times were recorded monthly at most of the sites. Measured data were computed for comparison with monthly reported data.

Comparisons between water pumpage calculated from noninvasive pipe-flow measurements and pump running times, and water pumpage reported to the ASWCC or ADH reveals variation between the measured and reported data. Less variation exists between water withdrawals calculated from noninvasive pipe-flow measurements and amounts calculated from inline flowmeter measurements. Variation in reporting accuracy among the water-supply facilities is to be expected. Each facility has a different level of capability to determine the amount of water it withdraws. However, at some facilities that are equipped with inline flowmeters there are still significant differences between measured and reported pumpage. It is considerably more difficult to determine the source of variation between measured and reported pumpage for a particular facility.

The variation between water pumpage measured by noninvasive flowmeters and reported to State agencies ranged from -253.6 percent to 85.4 percent. The variation between water pumpage measured by noninvasive flowmeter and by inline flowmeter ranged from - 125.4 percent to 90.2 percent. Overall there was significantly less variation between pumpage measured by the noninvasive and inline flowmeters. Ironically, there was virtually no difference in the average percent difference between amounts measured by noninvasive flowmeter and reported to the ASWCC for those sites equipped with an inline flowmeter, and those sites where an inline meter was not present. Even when an inline meter was present, some sites reported exactly the same water-use amount for each month during the investigation. 
Percent differences between water withdrawals measured by noninvasive flowmeter and amounts reported to the ASWCC and ADH were lower (21.3 percent for ASWCC; 20.3 percent for ADH) for those facilities that reported to both agencies than for those facilities that reported only to the ASWCC (29.9 percent). There were only three facilities that reported only to $\mathrm{ADH}$. Facilities that report to both agencies probably keep current records of pump running times and calculate water withdrawals periodically, and are therefore more likely to report water usage when requested by the individual agencies. Overall, facilities that reported to both agencies, reported equal or nearly equal amounts to both agencies.

Although it is difficult to assess the absolute accuracy of the reported data, it is apparent that considerable variation exists in the reported data. The average percent difference between water withdrawals measured by noninvasive meter and that reported to the ASWCC is about 26 percent. More information is needed to determine the source of variation between measured and reported water withdrawals.

\section{SELECTED REFERENCES}

Arvin, D.V., 1992, Feasibility of using portable, noninvasive pipe flowmeters and time totalizers for determining water use: U.S. Geological Survey Water-Resources Investigations Report 91-4110, 65 p.

Baker, N.T., Manning, C.A., and Beavers, E.A., 1991, Inventory of public water supplies in Arkansas: U.S. Geological Survey Open-File Report 91-247, 157 p.

Hurr, T.R., and Litke, D.W., 1989, Estimating pumping time and ground-water withdrawals using energyconsumption data: U.S. Geological Survey Water-Resources Investigations Report 89-4107, 27 p.

Solley, W.B., Merk, C.F., and Pierce, R.R., 1988, Estimated use of water in the United States in 1985: U.S. Geological Survey Circular 1004, $82 \mathrm{p}$. 


\title{
Table 1.--Description of selected public water-supply facilities in Arkansas and flow-measurement conditions at these sites, 1990
}

[Number in parentheses is facility identification number (fig. 1); ${ }^{* *}$, not applicable; hp, horsepower; DVTT, digital vibration time totalizer]

\begin{abstract}
Arkansas City Waterworks (30523)
Location: Desha County

Population served: 606

Source of water: Ground water

Pipe material: Ductile iron

Pipe diameter: 6.77 inches

Pipe thickness: 0.23 inch

Transducer spacing: **

Measurement condition rating: good

Comments: Arkansas City Waterworks has one 1.5-hp electric powered pump. Flow measurements were made at the pump with the reflective-doppler meter. Flow at the measurement point was horizontal. There is no inline flowmeter available at this location. Pump running times were calculated from metered energy consumption of the pump.
\end{abstract}

Bennett Acres Mobile Home Park (30543)

Location: Saline County

Population served: 81

Source of water: Ground water

Pipe material: Ductile iron

Pipe diameter: 1.43 inches

Pipe thickness: 0.15 inch

Transducer spacing: **

Measurement condition rating: good to fair

Comments: Bennett Acres Mobile Home Park has two electric powered pumps (0.75- and 1.5-hp). There is no inline flowmeter available at either location. Flow measurements were made at the 1.5-hp pump with the reflective-doppler flowmeter because the 0.75 -hp pump was used only as a backup pump. Flow at the measurement point was horizontal. A timer was placed on the pump by the operator to limit pumping because of the size of the water storage tank. This condition limited the amount for time available for making discharge measurements at this location. Pump running times were calculated from metered energy consumption of the pump.

Bergman Waterworks (30547)

Location: Boone County

Population served: 525

Source of water: Ground water

Pipe material: Ductile iron

Pipe diameter: 4.86 inches

Pipe thickness: 0.15 inch

Transducer spacing: **

Measurement condition rating: good

Comments: Bergman Waterworks has one 20-hp electric powered pump. There is an inline flowmeter available at this location. Flow measurements were made at the 20 -hp pump with the reflective-doppler flowmeter near the inline flowmeter. Flow at the measurement point was vertical-down. Pump running times were calculated from metered energy consumption of the pump. 
Bigelow Waterworks (30551)

Location: Perry County

Population served: 600

Source of water: Ground water

Pipe material: Ductile iron

Pipe diameter: 5.00 inches

Pipe thickness: 0.22 inch

Transducer spacing: **

Measurement condition rating: good

Comments: Bigelow Waterworks has one 25-hp electric powered pump. There was an inline flowmeter available at this location. Flow measurements were made at the pump with the reflectivedoppler flowmeter. Flow at the measurement point was horizontal. Pump running times were obtained from a log book of pump running times maintained by the plant operator.

Big Flat Waterworks (30550)

Location: Baxter County

Population served: 189

Source of water: Ground water

Pipe material: Ductile iron

Pipe diameter: 7.00 inches

Pipe thickness: 0.22 inch

Transducer spacing: **

Measurement condition rating: good

Comments: Big Flat Waterworks has two electric powered pumps (10-and 50-hp). An inline flowmeter was available at each location. Flow measurements were made at the 50-hp pump with the reflectivedoppler flowmeter. The 10-hp pump was not measured because it was used as a backup. Flow at the measurement point was horizontal. Pump running times were obtained from a log book of pump running times maintained by the plant operator.

Black Rock Waterworks (30556)

Location: Lawrence County

Population served: 912

Source of water: Ground water

Pipe material: Ductile iron

Pipe diameter: 3.25 inches

Pipe thickness: 0.21 inch

Transducer spacing: **

Measurement condition rating: Good

Comments: Black Rock Waterworks has one 25-hp electric powered pump. There was an inline flowmeter available at this location. Flow measurements were made at the pump with the reflectivedoppler flowmeter. Flow at the measurement point was horizontal. Pump running times were calculated from metered energy consumption of the pump. 
Calico Rock Waterworks (30576)

Location: Izard County

Population served: 1,500

Source of water: Ground water

Pipe material: Ductile iron

Pipe diameter: 3.75 inches

Pipe thickness: 0.75 inch

Transducer spacing: **

Measurement condition rating: Good

Comments: Calico Rock Waterworks has two 25-hp electric powered pumps. There was no inline flowmeter available at these locations. Flow measurements were near the pumps on a common pipe for both pumps with the reflective-doppler flowmeter. Flow at the measurement points was horizontal. Pump running time was obtained from a log book of pump running times maintained by the plant operator.

Camden Waterworks (20600)

Location: Ouachita County

Population served: 18,134

Source of water: Surface water, Ouachita River

Pipe material: Ductile iron

Pipe diameter: 12.82 inches

Pipe thickness: 0.38 inch

Transducer spacing: **

Measurement condition rating: Good to poor

Comments: Camden Waterworks has three 50 -hp electric powered pumps. Two of the pumps were used as primary sources of water, and the other was used as a standby. The original measurement point selected for making pumpage measurements at Camden was located at the water plant. At this measurement location the inflow pipe contained the cumulative flow of the three surface-water withdrawals. After making three measurements at this location and comparing them to measurements recorded within the plant, it was evident that our measurements discharge were well below those recorded within the plant. After discussion with the water superintendent, it was determined that the measurement location was close to the venturi located approximately 3 feet further down the discharge pipe. Therefore, on following site visits the flow was measured from three pumps (two primary, one standby) with the reflective-doppler flowmeter. These measurement locations worked well until January through April 1991 when the road from the back of the water plant toward the Ouachita River and the three pumps were flooded. After the river receded, data collection resumed. Flow at these measurement points was horizontal. Pump running times were obtained from a log book of pump running times maintained by the plant operator. 
Carthage Waterworks (30582)

Location: Dallas County

Population served: 600

Source of water: Ground water

Pipe material: Ductile iron

Pipe diameter: 5.62 inches

Pipe thickness: 0.37 inch

Transducer spacing: **

Measurement condition rating: Good

Comments: Carthage Waterworks has one 15-hp electric powered pump. There is an inline flowmeter available at the plant. Flow measurements were made at the plant near the inline flowmeter with the reflective-doppler flowmeter. Flow at the measurement point was horizontal. Access to the plant became a problem at times because of security reasons. Unless the water superintendent could be located, the datacollection personnel could not gain admission. Pump running times were obtained from a log book of pump running times maintained by the plant operator.

Cass Waterworks (30584)

Location: Franklin County

Population served: 250

Source of water: Surface water, Fane Creek

Pipe material: PVC

Pipe diameter: 3.50 inches

Pipe thickness: 0.25 inch

Transducer spacing: **

Measurement condition rating: Good

Comments: Cass Waterworks has one 15-hp electric powered pump. During the last 3 months of the data collection period (January through March 1991) an inline flowmeter was installed at this location. Flow measurements were made with the reflective-doppler flowmeter at the plant near the inline flowmeter. Flow at the measurement point was vertical-up. Pump running time was obtained from a log book of pump running times maintained by the plant operator.

Collins Water Association (30596)

Location: Drew County

Population served: 250

Source of water: Ground water

Pipe material: Ductile iron

Pipe diameter: 3.50 inches

Pipe thickness: 0.32 inch

Transducer spacing: **

Measurement condition rating: Good

Comments: Collins Water Association has one 20-hp electric powered pump. Flow measurements were made at the pump near the inline flowmeter with the reflective-doppler flowmeter. Flow at the measurement point was horizontal. Pump running times were calculated from metered energy consumption of the pump. 
Dierks Waterworks (30631)

Location: Howard County

Population served: 1,850

Source of water: Surface water, Dierks Lake

Pipe material: Ductile iron

Pipe diameter: 9.00 inches

Pipe thickness: 0.35 inch

Transducer spacing: **

Measurement condition rating: Good

Comments: Dierks Waterworks has two 15-hp electric powered pumps and an inline flowmeter. Both pumps run simultaneously. Flow measurements were made on a single pipe at the plant near the inline flowmeter with the reflective-doppler flowmeter. Flow at the measurement point was horizontal. Pump running time was obtained from a log book of pump running times maintained by the plant operator.

Franklin Waterworks (30666)

Location: Izard County

Population served: 253

Source of water: Ground water

Pipe material: Ductile iron

Pipe diameter: 2.25 inches

Pipe thickness: 0.20 inch

Transducer spacing: **

Measurement condition rating: Good

Comments: Franklin Waterworks has one 30 -hp electric powered pump. Flow measurements were made at the pump near the inline flowmeter with the reflective-doppler flowmeter. Flow at the measurement point was horizontal. Pump running times were calculated from metered energy consumption of the pump.

Gilmore Waterworks (30676)

Location: Crittenden County

Population served: 600

Source of water: Ground water

Pipe material: Ductile iron

Pipe diameter: 3.50 inches

Pipe thickness: 0.25 inch

Transducer spacing: **

Measurement condition rating: Good

Comments: Gilmore Waterworks has one 15-hp electric powered pump. Flow measurements were made at the pump near the inline flowmeter with the reflective-doppler flowmeter. Flow at the measurement point was horizontal. Pump running times were calculated from metered energy consumption of the pump. Access to the pump became a problem at times because of security reasons; unless the water superintendent could be located, the data-collection personnel could not gain admission. 
Green Forest Waterworks (30686)

Location: Carroll County

Population served: 4,731

Source of water: Surface water, Anderson Spring

Pipe material: Ductile iron

Pipe diameter: 9.00 inches

Pipe thickness: 0.40 inch

Transducer spacing: **

Measurement condition rating: Good

Comments: Green Forest Waterworks has two 100-hp electric powered pumps. Flow measurements were made at the pumps near Anderson Spring with the reflective-doppler flowmeter. Flow at the measurement points was horizontal. There was an inline flowmeter available at the plant. Pump running times were calculated from metered energy consumption of the pumps.

Guy Waterworks (30693)

Location: Faulkner County

Population served: 200

Source of water: Ground water

Pipe material: Ductile iron

Pipe diameter: 2.43 inches

Pipe thickness: 0.25 inch

Transducer spacing: **

Measurement condition rating: Good

Comments: Guy Waterworks has two 10-hp electric powered pumps. Flow measurements were made at the plant near the inline flowmeter with the reflective-doppler flowmeter. Flow at the measurement point was horizontal. Pump running time was obtained from a log book of pump running times maintained by the plant operator.

Harrell Waterworks (30699)

Location: Calhoun County

Population served: 351

Source of water: Ground water

Pipe material: Ductile iron

Pipe diameter: 4.86 inches

Pipe thickness: 0.40 inch

Transducer spacing: **

Measurement condition rating: Good

Comments: Harrell Waterworks has one 20-hp electric powered pump. Flow measurements were made at the pump near the inline flowmeter with the reflective-doppler flowmeter. Flow at the measurement point was horizontal. Pump running times were obtained from a log book of pump running times maintained by the plant operator. 
Haskell Waterworks (30702)

Location: Saline County

Population served: 1,200

Source of water: Ground water

Pipe material: Ductile iron

Pipe diameter: 3.58 inches

Pipe thickness: 0.36 inch

Transducer spacing: **

Measurement condition rating: Good

Comments: Haskell Waterworks has two 15-hp electric powered pumps. Flow measurements were made at each pump near inline flowmeters with the reflective-doppler flowmeter. Flow at the measurement point was horizontal. Pump running times were obtained from a log book of pump running times maintained by the plant operator.

Holly Grove Waterworks (30713)

Location: Monroe County

Population served: 840

Source of water: Ground water

Pipe material: Ductile iron

Pipe diameter: 7.00 inches

Pipe thickness: 0.41 inch

Transducer spacing: **

Measurement condition rating: Good

Comments: Holly Grove Waterworks has one 25-hp electric powered pump. Flow measurements were made at the plant near inline flowmeter with the reflective-doppler flowmeter. Flow at the measurement point was horizontal. Pump running times were obtained from a log book of pump running times maintained by the plant operator.

Hoxie Waterworks (30719)

Location: Lawrence County

Population served: 2,961

Source of water: Ground water

Pipe material: Ductile iron

Pipe diameter: 7.00 inches

Pipe thickness: 0.41 inch

Transducer spacing: **

Measurement condition rating: Good

Comments: Hoxie Waterworks has two 25-hp electric powered pumps. There was no inline flowmeter available at either location. Flow measurements were made at the 25 -hp pump near the Hoxie Service Center with the reflective-doppler flowmeter. The other 25 -hp pump behind the water tower was not measured because it was used as a backup. Flow at the measurement point was horizontal. Pump running times were calculated from metered energy consumption of the pump. 
Huntsville Waterworks (30723)

Location: Madison County

Population served: 3,890

Source of water: Surface water, War Eagle Creek

Pipe material: Ductile iron

Pipe diameter: 12.00 inches

Pipe thickness: 0.34 inch

Transducer spacing: 12.00 inches

Measurement condition rating: Good

Comments: Huntsville Waterworks has two 125-hp electric powered pumps. Flow measurements were made at the plant near the inline flowmeter with the time-of-flight type flowmeter. Flow at the measurement point was horizontal. Pump running time was obtained from a log book of pump running times maintained by the plant operator.

Marianna Waterworks (30778)

Location: Lee County

Population served: 12,915

Source of water: Ground water

Pipe material: Ductile iron

Pipe diameter: 13.86 inches

Pipe thickness: 0.23 inch

Transducer spacing: **

Measurement condition rating: Good

Comments: Marianna Waterworks has four 50-hp natural gas powered pumps. Flow measurements were made at each pump with the reflective-doppler flowmeter. Flow at the measurement points was horizontal. There was an inline flowmeter available at the plant. DVTT's were used to record duration of pumping at each well.

Mountain Home Waterworks (30812)

Location: Baxter County

Population served: 15,943

Source of water: Surface water, Norfork Lake

Pipe material: Ductile iron

Pipe diameter: 12.00 inches

Pipe thickness: 0.56 inch

Transducer spacing: 8.00 inches

Measurement condition rating: Good to fair

Comments: Mountain Home Waterworks has three 125-hp electric powered pumps. Inline flow meters were not present on any of the pumps. Flow measurements were made at each pump near Norfork Lake with the time-of-flight flowmeter. Flow at each measurement point was horizontal. The discharge pipes for all three pumps merged to one main discharge pipe. This situation caused the DVTT's not to function as planned because when one pump was operating, the vibration of the pump was not only picked up by the DVTT on this pump but by DVTT's on the other pumps as well. DVTT records were compared with duration of pumping records maintained by the plant operator. 
Norphlet Waterworks (30830, well 1)

Location: Union County

Population served: 1,000

Source of water: Ground water

Pipe material: Ductile iron

Pipe diameter: 6.60 inches

Pipe thickness: 0.13 inch

Transducer spacing: **

Measurement condition rating: Good

Comments: Norphlet Waterworks has two electric powered pumps (40- and 50-hp). Flow measurements were made at the 50-hp pump near the inline flowmeter with the reflective-doppler flowmeter. Flow at the measurement point was horizontal. Pump running times were calculated from metered energy consumption of the pump.

Norphlet Waterworks (30830, well 2)

Location: Union County

Population served: 1,000

Source of water: Ground water

Pipe material: Ductile iron

Pipe diameter: 7.00 inches

Pipe thickness: 0.21 inch

Transducer spacing: **

Measurement condition rating: Good

Comments: Norphlet Waterworks has two electric powered pumps (40- and 50-hp). Flow measurements were made at the 40-hp pump (near the inline flowmeter) and at the 50-hp pump (no inline meter) with the reflective-doppler flowmeter. Flow at the measurement point was horizontal. Pump running times were calculated from metered energy consumption of the pump.

Ogden Waterworks (30836)

Location: Little River County

Population served: 500

Source of water: Ground water

Pipe material: Ductile iron

Pipe diameter: 4.58 inches

Pipe thickness: 0.21 inch

Transducer spacing: ${ }^{* *}$

Measurement condition rating: Good

Comments: Ogden Waterworks has two 10 -hp electric powered pumps. Flow measurements were made at each 10-hp pump near the inline flowmeter with the reflective-doppler flowmeter. Flow at each measurement point was horizontal. Pump running times were calculated from metered energy consumption of the pump. 
Oxford Waterworks (30843)

Location: Izard County

Population served: 520

Source of water: Ground water

Pipe material: Ductile iron

Pipe diameter: 3.25 inches

Pipe thickness: 0.51 inch

Transducer spacing: **

Measurement condition rating: Good

Comments: Oxford Waterworks has one 15-hp electric powered pump. Flow measurements were made at the 15-hp pump near the inline flowmeter with the reflective-doppler flowmeter. Flow at the measurement point was horizontal. Pump running times were calculated from metered energy consumption of the pump.

Parkin Waterworks (30852)

Location: Cross County

Population served: 2,100

Source of water: Ground water

Pipe material: Ductile iron

Pipe diameter: 7.00 inches

Pipe thickness: 0.26 inch

Transducer spacing: **

Measurement condition rating: Good

Comments: Parkin Waterworks has one 20- and one 25-hp electric powered pumps. There was no inline flowmeter available at either pump. Flow measurements were made at each pump with the reflective-doppler flowmeter. Flow at each measurement point was horizontal. Pump running times were calculated from metered energy consumption of the pump.

Perryville Waterworks (30859)

Location: Perry County

Population served: 3,988

Source of water: Surface water, Cedar Creek

Pipe material: Ductile iron

Pipe diameter: 7.00 and 6.00 inches

Pipe thickness: 0.55 and 0.52 inch

Transducer spacing: **

Measurement condition rating: Good

Comments: Perryville Waterworks has two 40-hp electric powered pumps. Flow measurements were made at each pump near the inline flowmeter with the reflective-doppler flowmeter. Flow at each measurement point was horizontal. Pump running time was obtained from a log book of pump running times maintained by the plant operator. 
Prairie Grove Waterworks (30871)

Location: Washington County

Population served: 3,033

Source of water: Surface water, Cedar Creek

Pipe material: Ductile iron

Pipe diameter: 10.00 inches

Pipe thickness: 0.52 inch

Transducer spacing: 12.00 inches

Measurement condition rating: Good

Comments: Prairie Grove Waterworks has two 40-hp electric powered pumps. Flow measurements were made at the plant near the inline flowmeter with the time-of-flight flowmeter. Flow at the measurement point was horizontal. Pump running time was obtained from a log book of pump running times maintained by the plant operator.

Roe Waterworks (30894)

Location: Monroe County

Population served: 200

Source of water: Ground water

Pipe material: Ductile iron

Pipe diameter: 4.58 inches

Pipe thickness: 0.33 inch

Transducer spacing: **

Measurement condition rating: Good

Comments: Roe Waterworks has one 20-hp electric powered pump. Flow measurements were made at the pump near the inline flowmeter with the reflective-doppler flowmeter. Flow at the measurement point was horizontal. Pump running times were calculated from metered energy consumption of the pump.

Russell Waterworks (30896)

Location: Monroe County

Population served: 500

Source of water: Ground water

Pipe material: Ductile iron

Pipe diameter: 6.25 inches

Pipe thickness: 0.38 inch

Transducer spacing: ${ }^{* *}$

Measurement condition rating: Good

Comments: Russell Waterworks has one 7.5-hp electric powered pump. Flow measurements were made at the pump with the reflective-doppler flowmeter. There was no inline flowmeter available at the pump. Flow at the measurement point was horizontal. Pump running times were calculated from metered energy consumption of the pump. 
Sidney Waterworks (30916)

Location: Sharp County

Population served: 270

Source of water: Ground water

Pipe material: Ductile iron

Pipe diameter: 3.40 inches

Pipe thickness: 0.25 inch

Transducer spacing: **

Measurement condition rating: Good

Comments: Sidney Waterworks has one 10 -hp electric powered pump. Flow measurements were made at the pump near the inline flowmeter with the reflective-doppler flowmeter. Flow at the measurement point was horizontal. Pump running times were calculated from metered energy consumption of the pump.

St. Paul Waterworks (30925)

Location: Madison County

Population served: 175

Source of water: Ground water

Pipe material: Ductile iron

Pipe diameter: 2.25 inches

Pipe thickness: 0.20 inch

Transducer spacing: **

Measurement condition rating: Good

Comments: St. Paul Waterworks has one 1-hp and one 0.75-hp electric powered pumps. Flow measurements were made at each pump near the inline flowmeter with the reflective-doppler flowmeter. Flow at each measurement point was horizontal. Pump running times were calculated from metered energy consumption of the pump.

Stamps Waterworks (30926)

Location: Lafayette County

Population served: 2,897

Source of water: Ground water

Pipe material: Ductile iron

Pipe diameter: 4.85 inches

Pipe thickness: 0.44 inch

Transducer spacing: **

Measurement condition rating: Good

Comments: Stamps Waterworks has three 40-hp electric powered pumps. Flow measurements were made at the plant near the inline flowmeter with the reflective-doppler flowmeter. Flow at the measurement point was horizontal. Pump running time was obtained from a log book of pump running times maintained by the plant operator. 
Stuttgart Waterworks - new water treatment plant (30932)

Location: Arkansas County

Population served: 17,250

Source of water: Ground water

Pipe material: Ductile iron

Pipe diameter: 11.15 inches

Pipe thickness: 0.29 inch

Transducer spacing: **

Measurement condition rating: Good

Comments: Stuttgart Waterworks (new water treatment plant) is served by two 100 -hp electric powered pumps. Flow measurements were made at the plant near the inline flowmeter with the reflectivedoppler flowmeter. Flow at the measurement point was horizontal. Pump running time was obtained from a log book of pump running times maintained by the plant operator.

Stuttgart Waterworks - old water treatment plant (30932)

Location: Arkansas County

Population served: 17,250

Source of water: Ground water

Pipe material: Ductile iron

Pipe diameter: 16.00 inches

Pipe thickness: 0.26 inch

Transducer spacing: 12.00 inches

Measurement condition rating: Good

Comments: Stuttgart Waterworks (old water treatment plant) is served by three electric powered pumps (two 125-hp and one 100-hp). Flow measurements were made at the plant near the inline flowmeter with the time-of-flight flowmeter. Flow at the measurement point was vertical-up. Pump running time was obtained from a log book of pump running times maintained by the plant operator.

Thornton Waterworks (30945)

Location: Calhoun County

Population served: 759

Source of water: Ground water

Pipe material: Ductile iron

Pipe diameter: 6.75 inches

Pipe thickness: 0.31 inch

Transducer spacing: **

Measurement condition rating: Good

Comments: Thornton Waterworks has one 20-hp electric powered pump. Flow measurements were made at the pump near the inline flowmeter with the reflective-doppler flowmeter. Flow at each measurement point was horizontal. Pump running time was obtained from a log book of pump running times maintained by the plant operator. 
Trumann Waterworks - City Hall Well (30950)

Location: Poinsett County

Population served: 7,454

Source of water: Ground water

Pipe material: Ductile iron

Pipe diameter: 10.00 inches

Pipe thickness: 0.52 inch

Transducer spacing: **

Measurement condition rating: Good

Comments: Trumann Waterworks has two electric powered pumps and no inline flowmeters. Flow measurements were made at the 40 -hp pump near City Hall with the reflective-doppler flowmeter. Flow at the measurement point was vertical-down. Pump running times were calculated from metered energy consumption of the pump.

Trumann Waterworks - Davis Street (30950)

Location: Poinsett County

Population served: 7,454

Source of water: Ground water

Pipe material: Ductile iron

Pipe diameter: 8.00 inches

Pipe thickness: 0.39 inch

Transducer spacing: **

Measurement condition rating: Good

Comments: Trumann Waterworks has two electric powered pumps and no inline flowmeters. Flow measurements were made at the 60 -hp pump near the water plant with the reflective-doppler flowmeter. Flow at the measurement point was horizontal. Pump running times were calculated from metered energy consumption of the pump.

Ward Waterworks - Well 1 (30969)

Location: Lonoke County

Population served: 7,713

Source of water: Ground water

Pipe material: Ductile iron

Pipe diameter: 9.32 inches

Pipe thickness: 0.48 inch

Transducer spacing: **

Measurement condition rating: Good

Comments: Ward Waterworks has four electric powered pumps (15-, 20-, 25-, and 40-hp) and no inline flowmeter. Flow measurements were made at Well $1(15-\mathrm{hp})$ with the reflective-doppler flowmeter. Well 1 was primarily used for backflushing of lines, and as a standby well. Flow at the measurement point was horizontal. Pump running times were calculated from metered energy consumption of the pump. 
Ward Waterworks - Well 2 (30969)

Location: Lonoke County

Population served: 7,713

Source of water: Ground water

Pipe material: Ductile iron

Pipe diameter: 5.96 inches

Pipe thickness: 0.49 inch

Transducer spacing: **

Measurement condition rating: Good

Comments: Ward Waterworks has four electric powered pumps ((15-, 20-, 25-, and 40-hp) and no inline flowmeter. Flow measurements were made at Well $2(25-\mathrm{hp})$ with the reflective-doppler flowmeter. Flow at the measurement point was horizontal. Pump running times were calculated from metered energy consumption of the pump.

Ward Waterworks - Well 3 (30969)

Location: Lonoke County

Population served: 7,713

Source of water: Ground water

Pipe material: Ductile iron

Pipe diameter: 7.00 inches

Pipe thickness: 0.50 inch

Transducer spacing: **

Measurement condition rating: Good

Comments: Ward Waterworks has four electric powered pumps (15-, 20-, 25-, and 40-hp) and no inline flowmeter. Flow measurements were made at Well $3(20-\mathrm{hp})$ with the reflective-doppler flowmeter. Well 3 was primarily used for backflushing of lines and as a standby well. Flow at the measurement point was horizontal. Pump running times were calculated from metered energy consumption of the pump.

Ward Waterworks - Well 4 (30969)

Location: Lonoke County

Population served: 7,713

Source of water: Ground water

Pipe material: Ductile iron

Pipe diameter: 10.47 inches

Pipe thickness: 0.36 inch

Transducer spacing: **

Measurement condition rating: Good

Comments: Ward Waterworks has four electric powered pumps (15-, 20-, 25-, and 40-hp) and no inline flowmeter. Flow measurements were made at Well $4(40-\mathrm{hp})$ with the reflective-doppler flowmeter. Flow at the measurement point was horizontal. Pump running times were calculated from metered energy consumption of the pump. 
Warren Waterworks - Wells 1 and 2 (30970)

Location: Bradley County

Population served: 9,000

Source of water: Ground water

Pipe material: Ductile iron

Pipe diameter: 9.00 inches

Pipe thickness: 0.54 inch

Transducer spacing: **

Measurement condition rating: Good

Comments: Warren Waterworks has three electric powered pumps (two 20- and a 40-hp). Flow measurements were made at Wells 1 and 2 (20-hp pumps) with the reflective-doppler flowmeter. An inline flowmeter was not present at these pumps. Flow at the measurement point was horizontal. Pump running time was obtained from a log book of pump running times maintained by the plant operator.

Warren Waterworks - Well 3 (30970)

Location: Bradley County

Population served: 9,000

Source of water: Ground water

Pipe material: Ductile iron

Pipe diameter: 13.20 inches

Pipe thickness: 0.49 inch

Transducer spacing: **

Measurement condition rating: Good

Comments: Warren Waterworks has three electric powered pumps (two 20- and a 40-hp). Flow measurements were made at Well 3 (40-hp pump) with the reflective-doppler flowmeter. An inline flowmeter was present at Well 3. Flow at the measurement point was horizontal. Pump running time was obtained from a log book of pump running times maintained by the plant operator.

Wright-Pastoria Water Association (30999)]

Location: Jefferson County

Population served: 1,640

Source of water: Ground water

Pipe material: Ductile iron

Pipe diameter: 5.00 inches

Pipe thickness: 0.31 inch

Transducer spacing: **

Measurement condition rating: Good

Comments: Wright-Pastoria Water Association has one 15-hp electric powered pump. Flow measurements were made at the pump near the inline flowmeter with the reflective-doppler flowmeter. Flow at the measurement point was horizontal. Pump running times were calculated from metered energy consumption of the pump and from operator logs. 
Yorktown Water Association - Well 1 (31004)

Location: Lincoln County

Population served: 7,500

Source of water: Ground water

Pipe material: Ductile iron

Pipe diameter: 7.00 inches

Pipe thickness: 0.41 inch

Transducer spacing: **

Measurement condition rating: Good

Comments: Yorktown Water Association has four electric powered pumps (one 50-, two 60-, and one 75-hp). Flow measurements were made at one 60-hp pump near the inline flowmeter with the reflectivedoppler flowmeter. Flow at the measurement point was horizontal. Pump running times were calculated from metered energy consumption of the pump.

Yorktown Water Association - Well 2 (31004)

Location: Lincoln County

Population served: 7,500

Source of water: Ground water

Pipe material: Ductile iron

Pipe diameter: 7.00 inches

Pipe thickness: 0.46 inch

Transducer spacing: **

Measurement condition rating: Good

Comments: Yorktown Water Association has four electric powered pumps (one 50-, two 60-, and one 75-hp). Flow measurements were made at the 75-hp pump near the inline flowmeter with the reflectivedoppler flowmeter. Flow at the measurement point was horizontal. Pump running times were calculated from metered energy consumption of the pump.

Yorktown Water Association - Well 3 (31004)

Location: Lincoln County

Population served: 7,500

Source of water: Ground water

Pipe material: Ductile iron

Pipe diameter: 7.00 inches

Pipe thickness: 0.36 inch

Transducer spacing: **

Measurement condition rating: Good

Comments: Yorktown Water Association has four electric powered pumps (one 50-, two 60-, and one 75-hp). Flow measurements were made at the 50-hp pump near the inline flowmeter with the reflectivedoppler flowmeter. Flow at the measurement point was horizontal. Pump running times were calculated from metered energy consumption of the pump. 
Yorktown Water Association - Well 5 (31004)

Location: Lincoln County

Population served: 7,500

Source of water: Ground water

Pipe material: Ductile iron

Pipe diameter: 7.00 inches

Pipe thickness: 0.38 inch

Transducer spacing: **

Measurement condition rating: Good

Comments: Yorktown Water Association has four electric powered pumps (one 50-, two 60-, and one 75-hp). Flow measurements were made at one 60-hp pump near the inline flowmeter with the reflectivedoppler flowmeter. Flow at the measurement point was horizontal. Pump running times were calculated from metered energy consumption of the pump. 


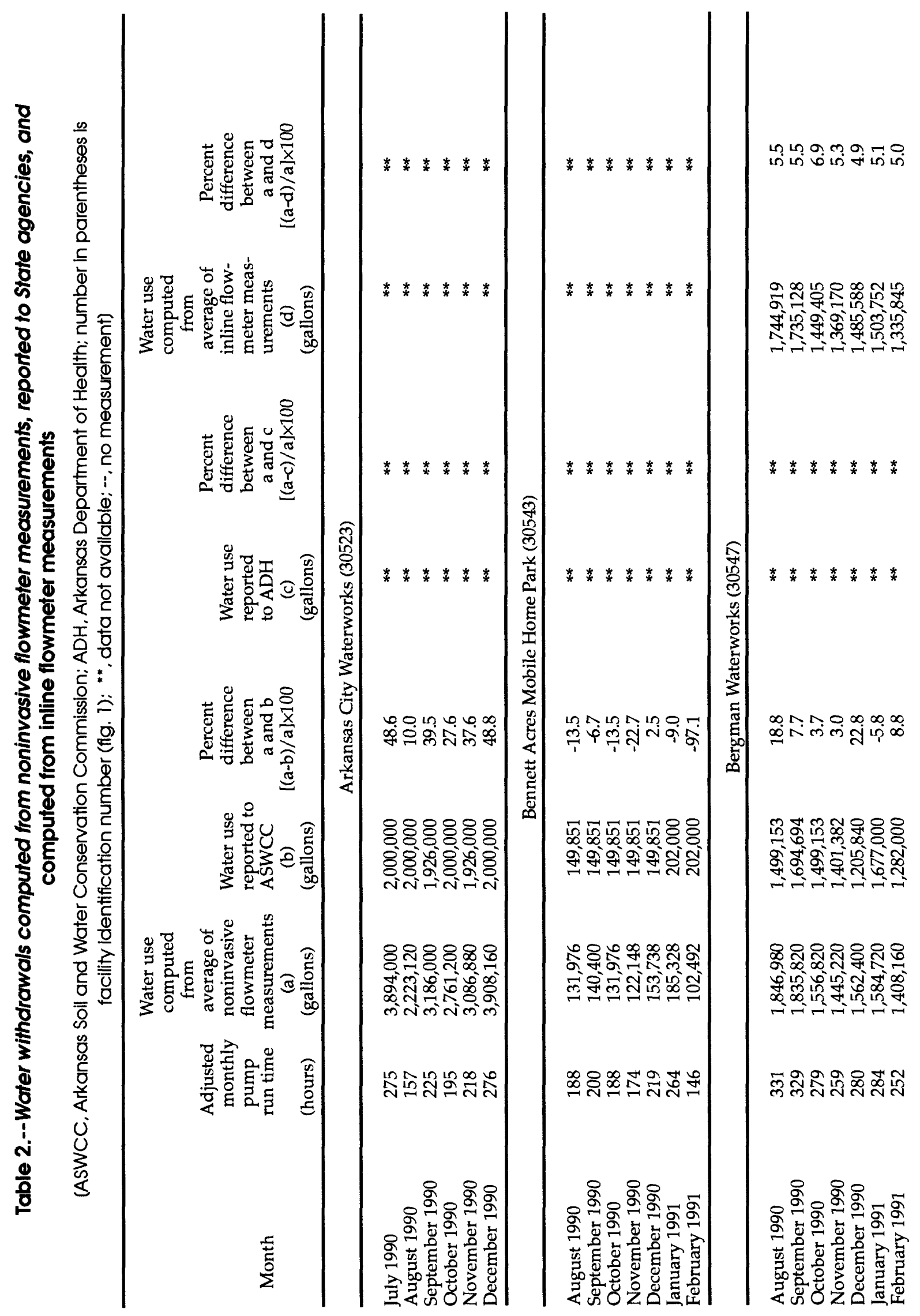




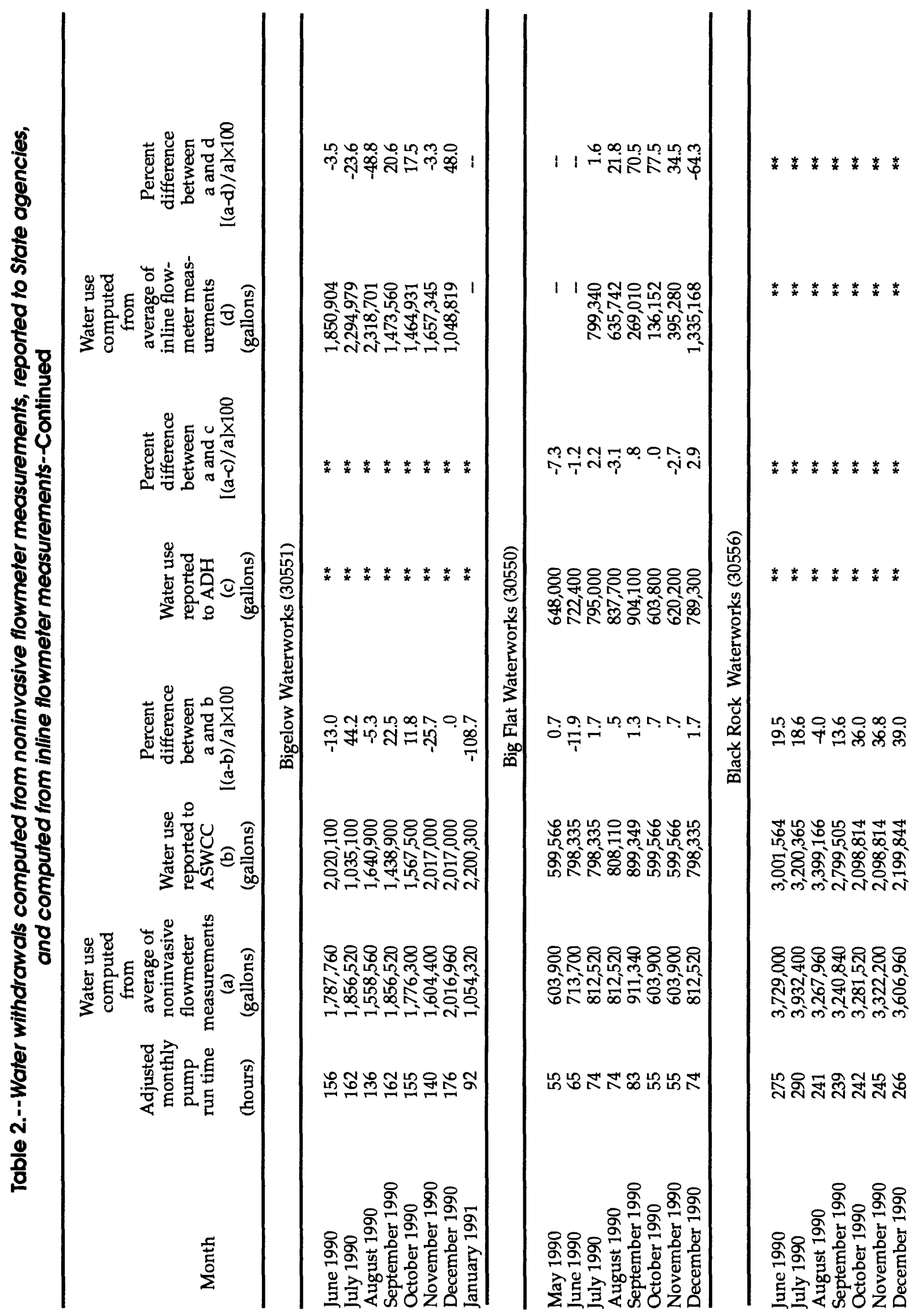




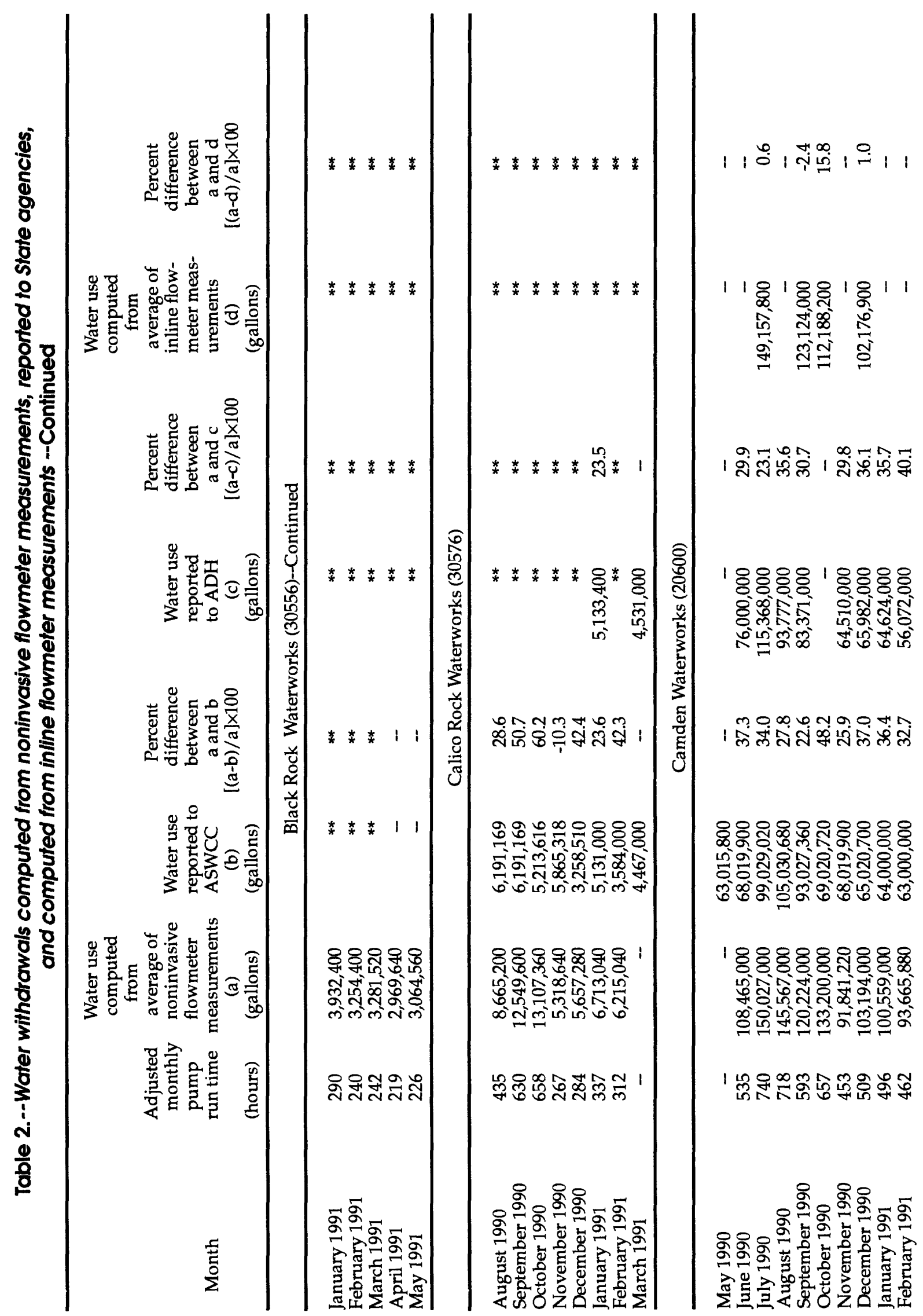




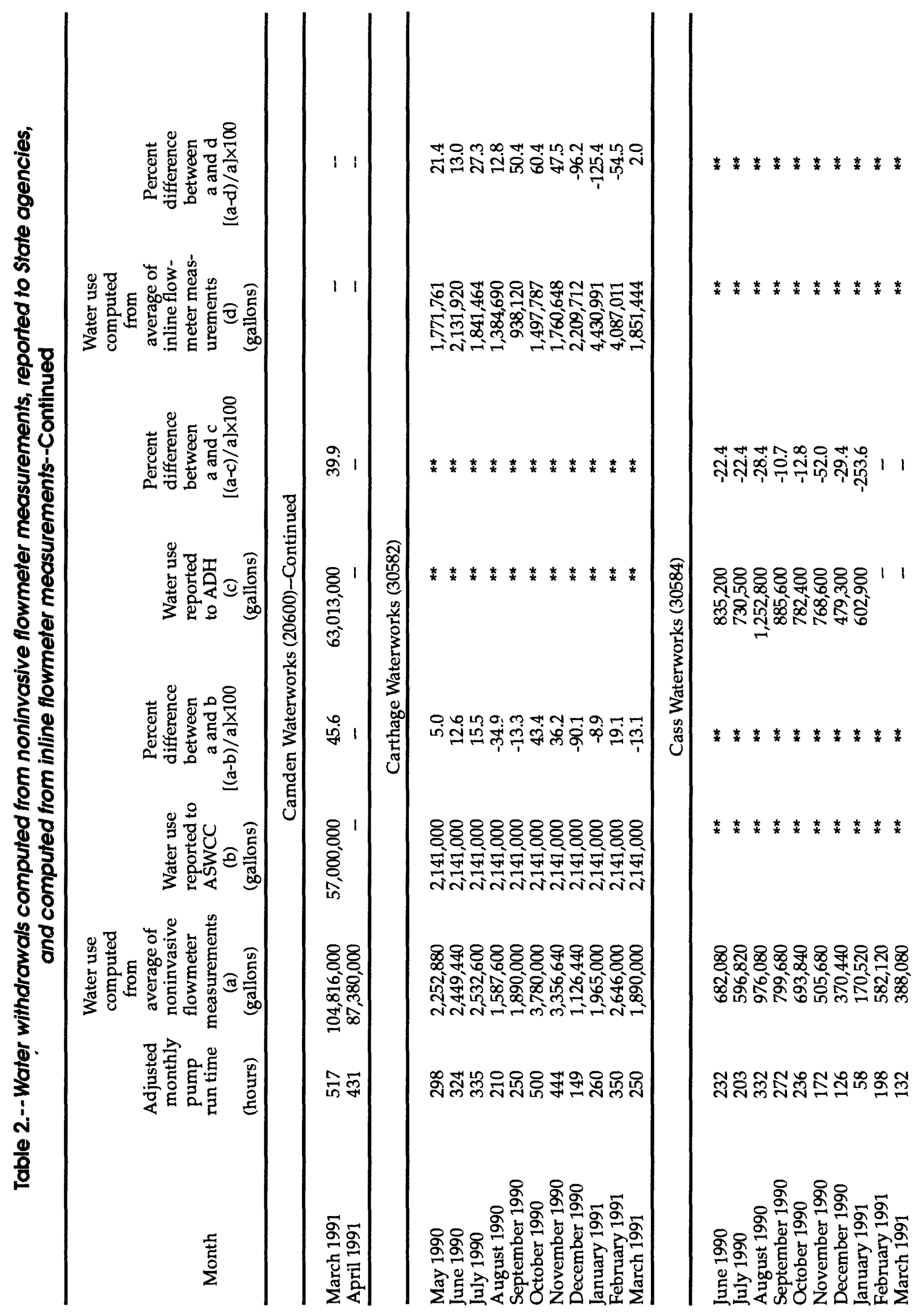




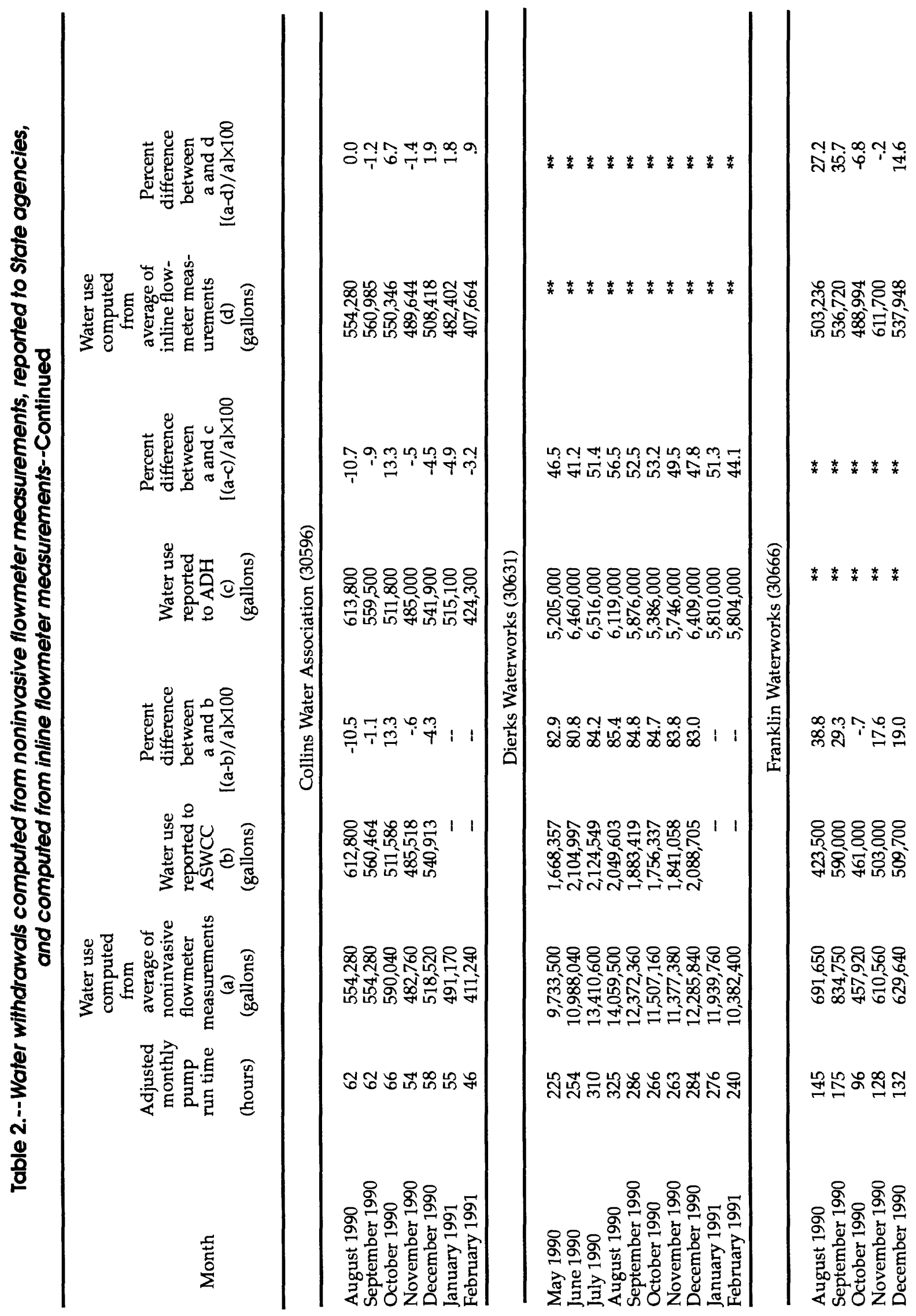




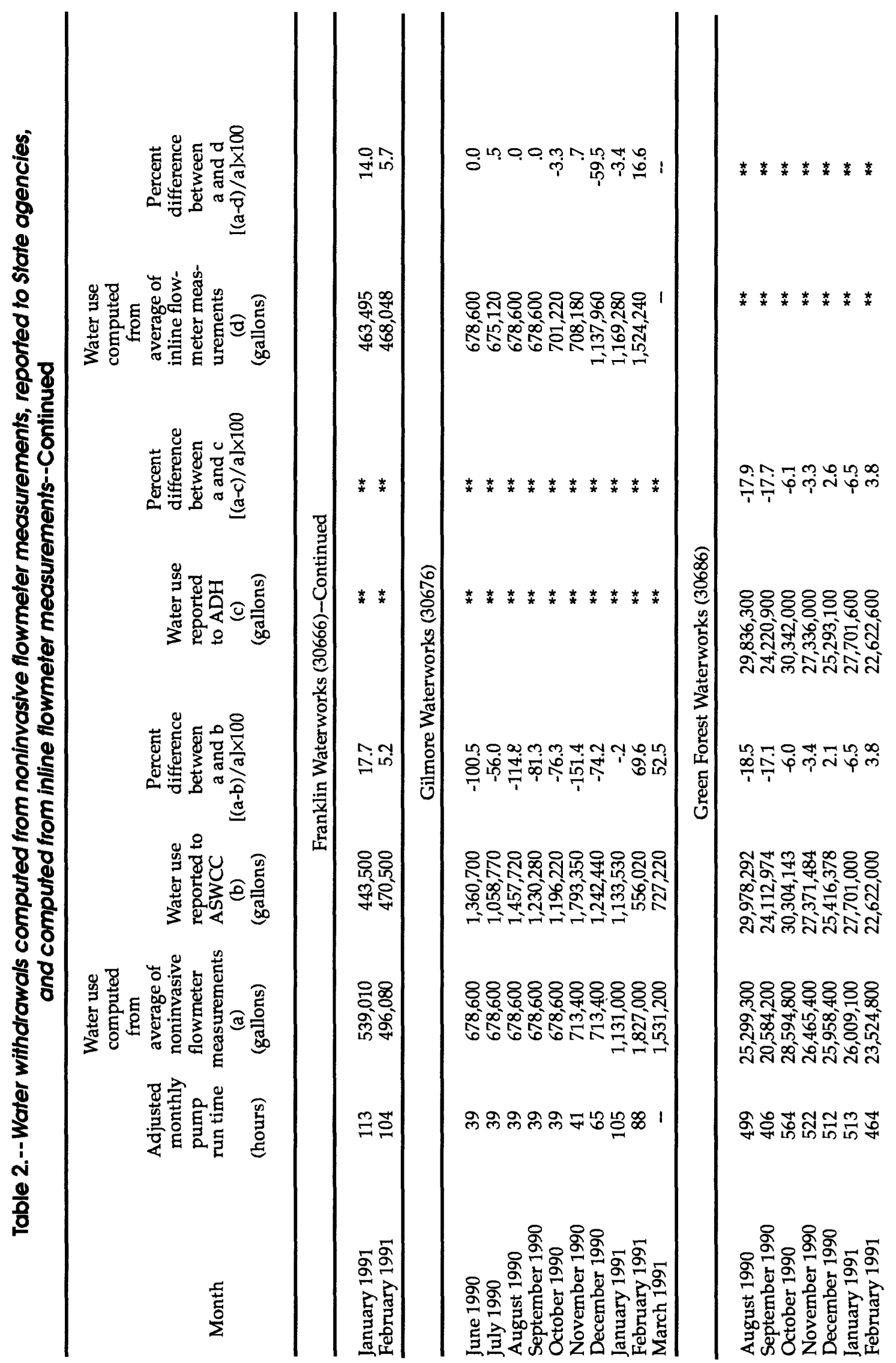




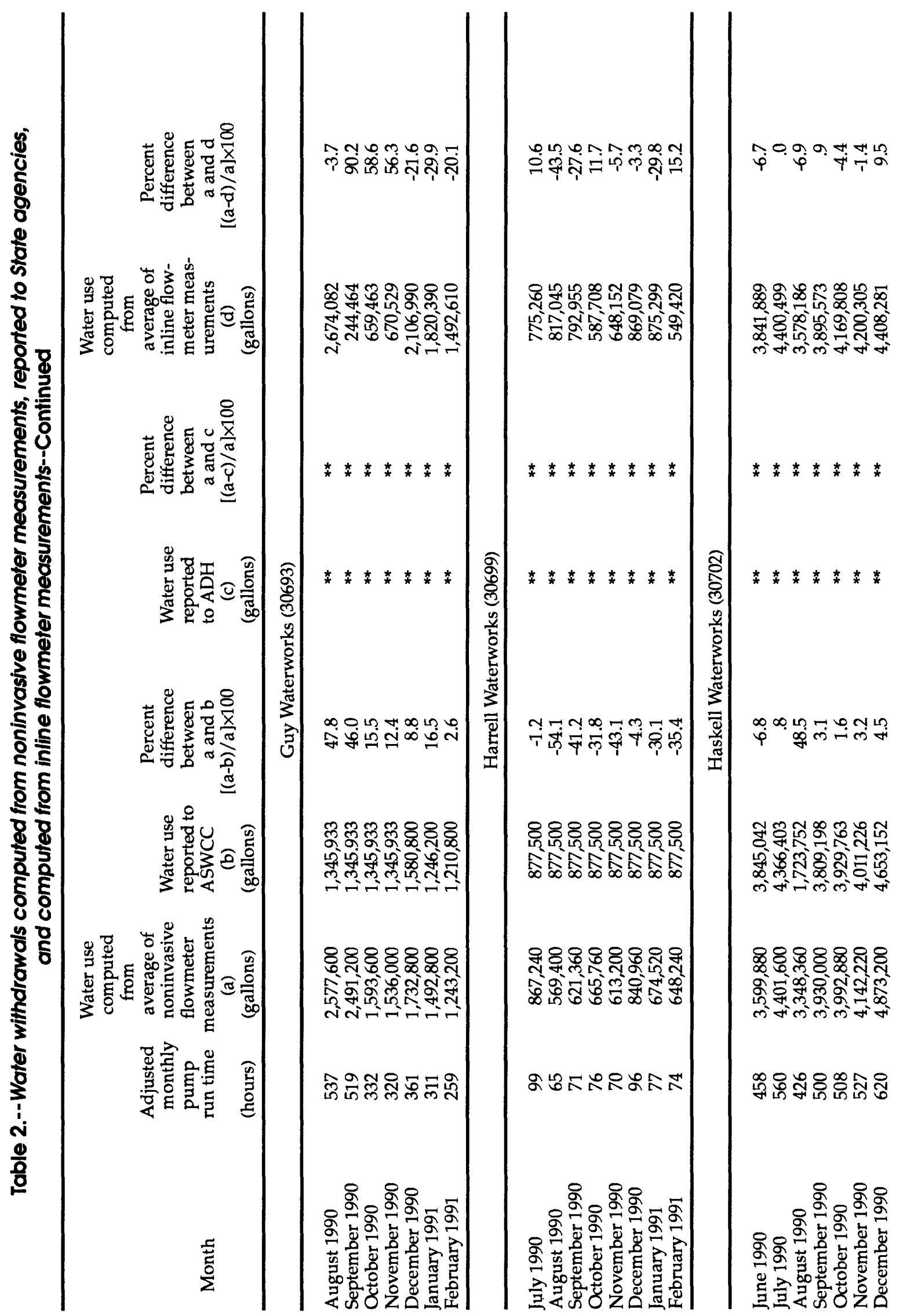




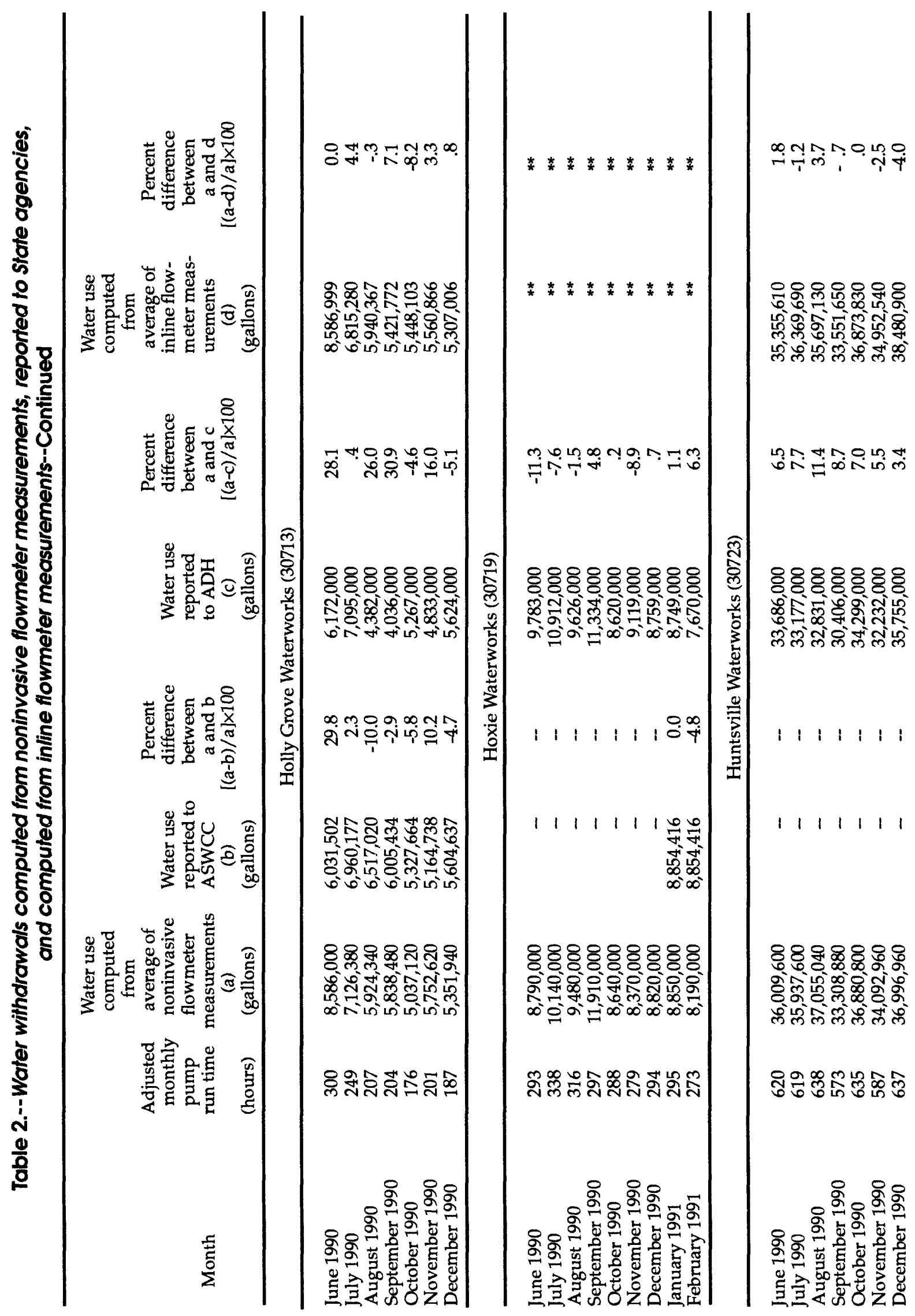




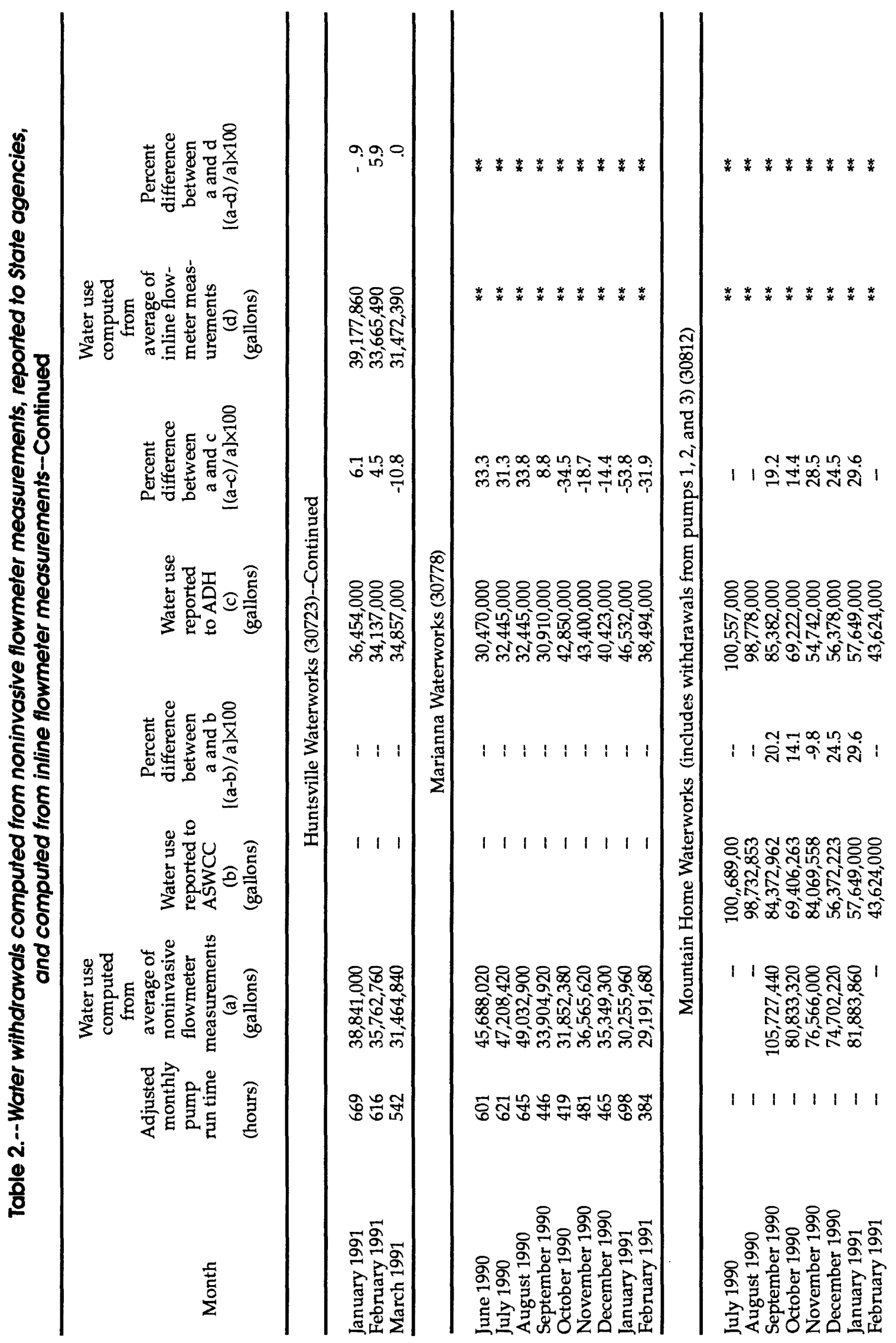




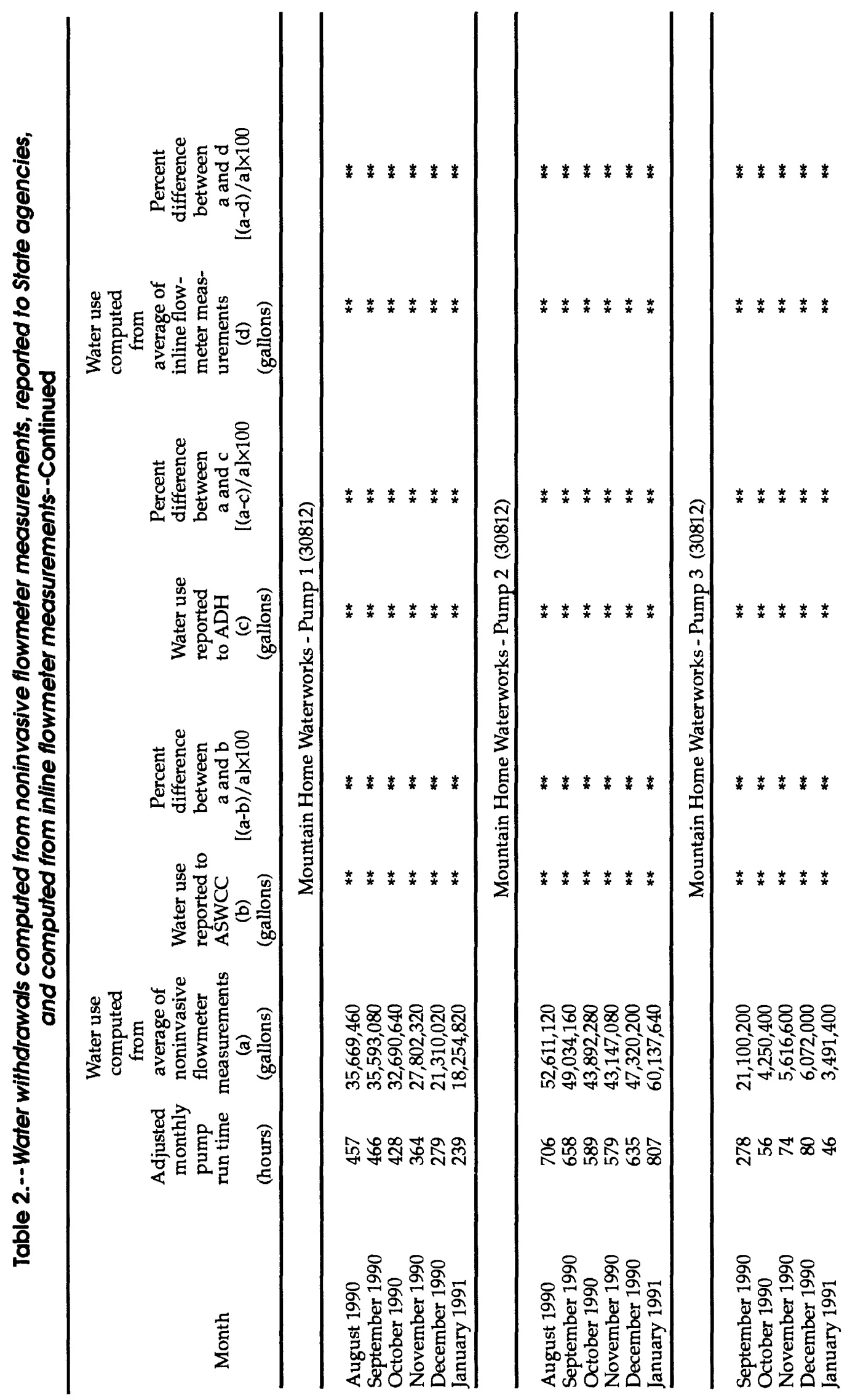




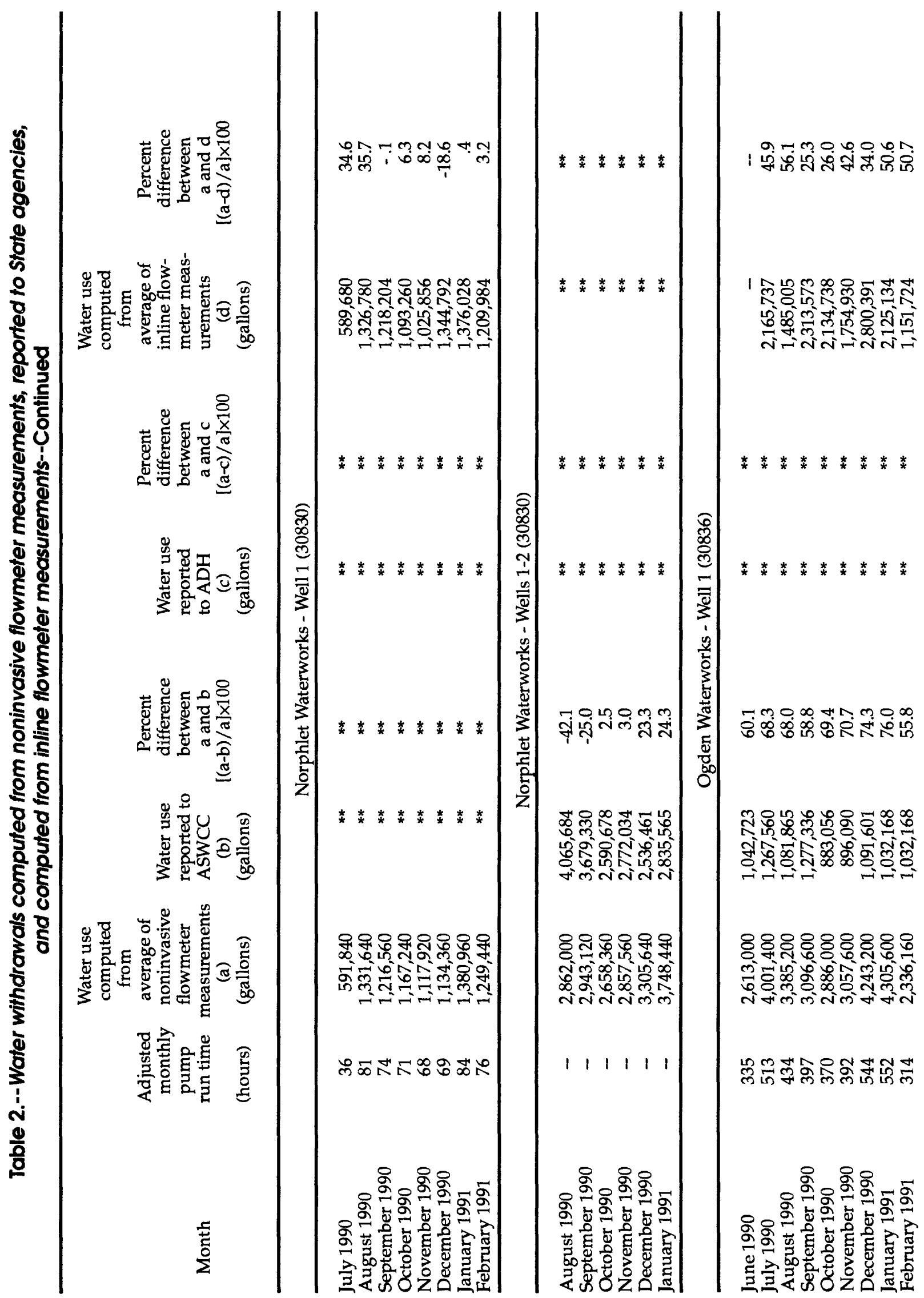




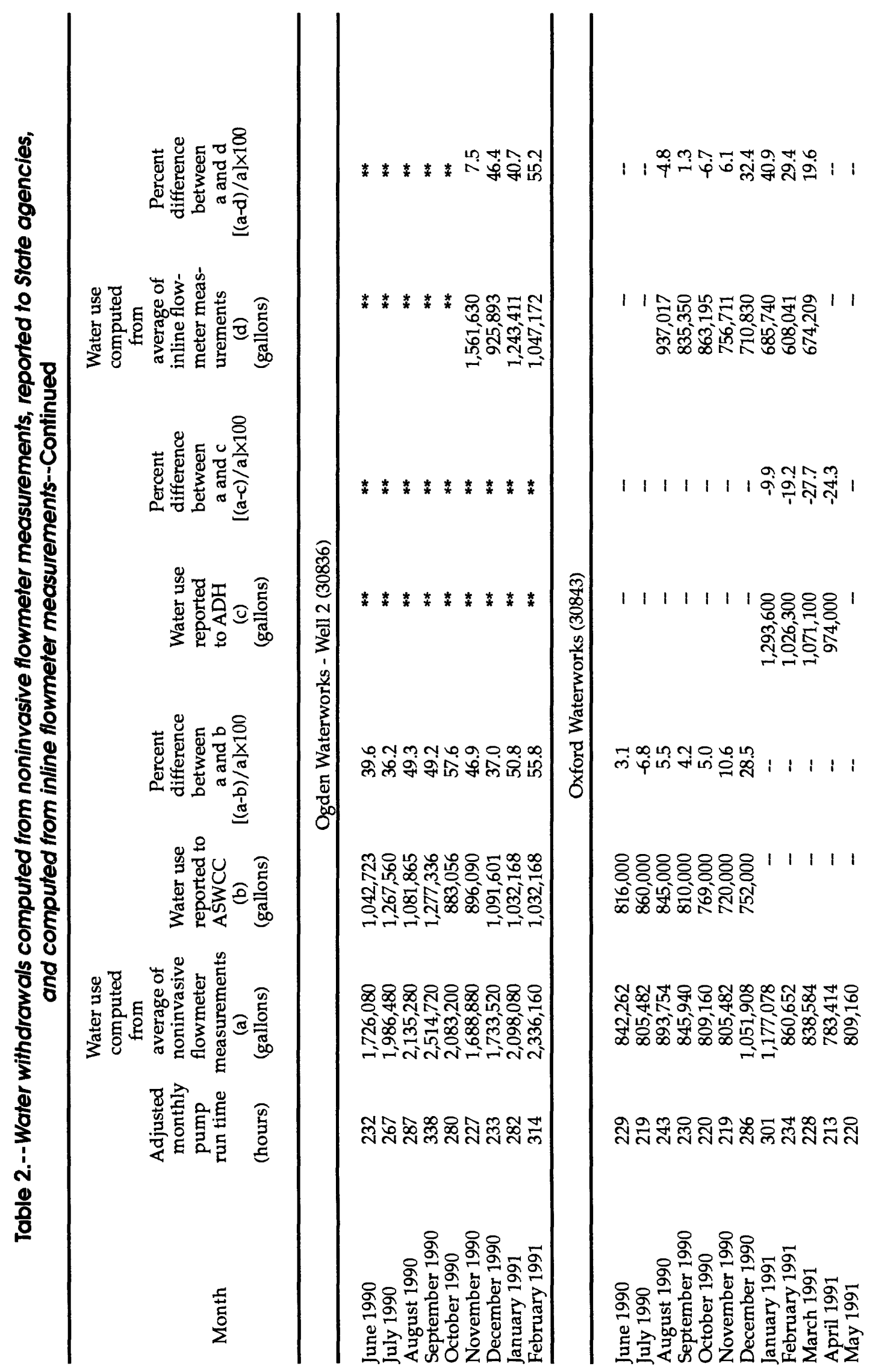




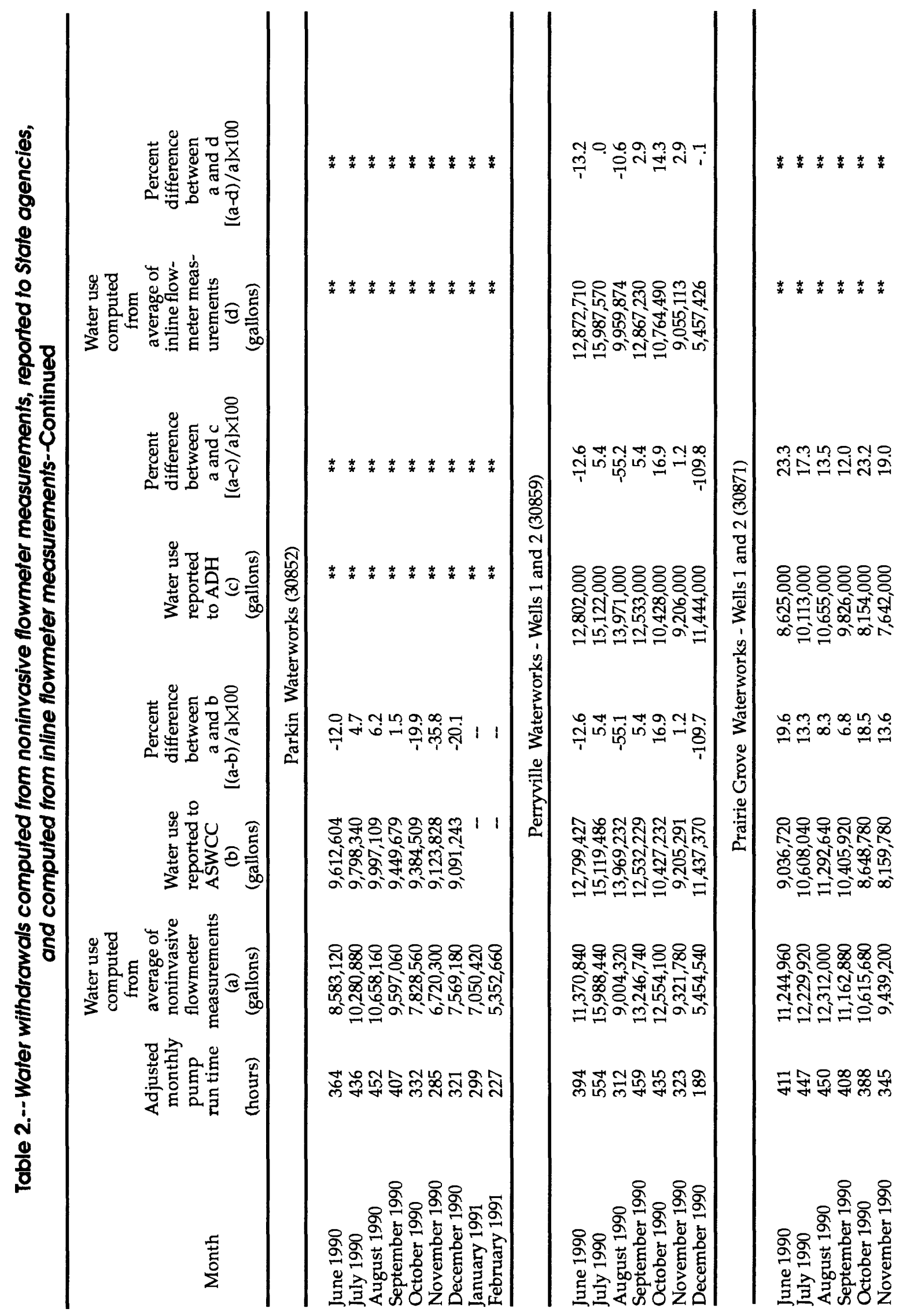




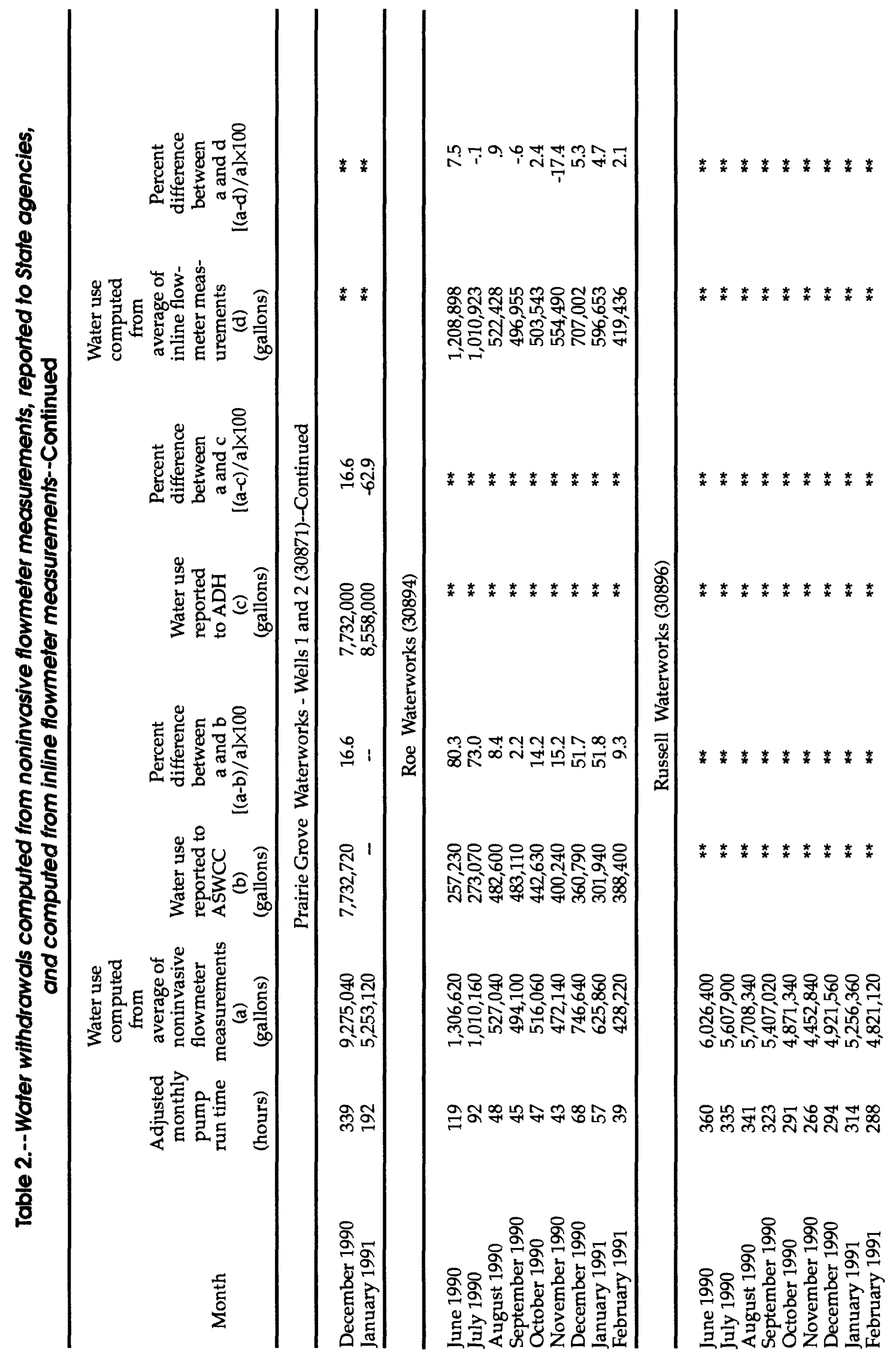




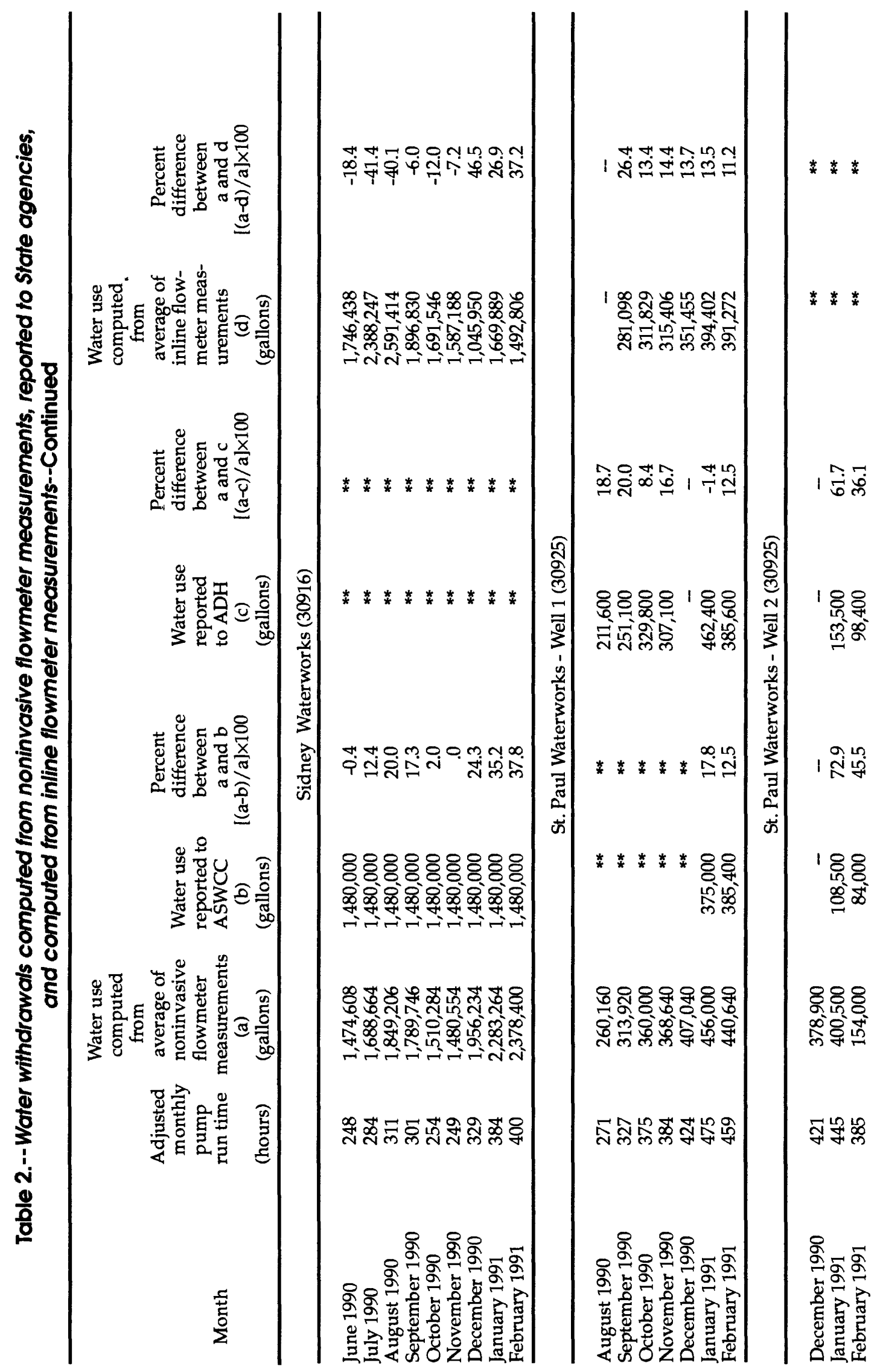




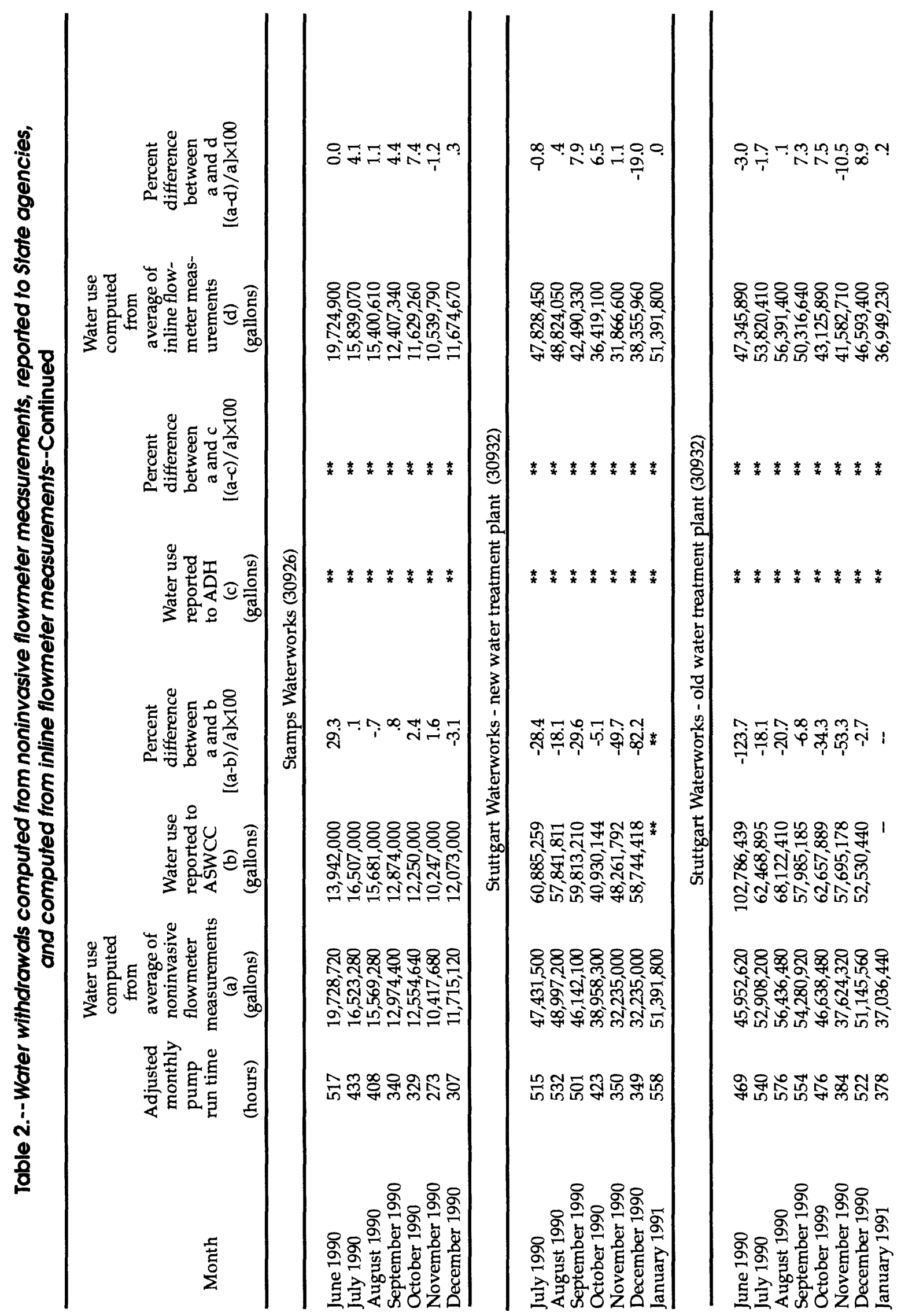




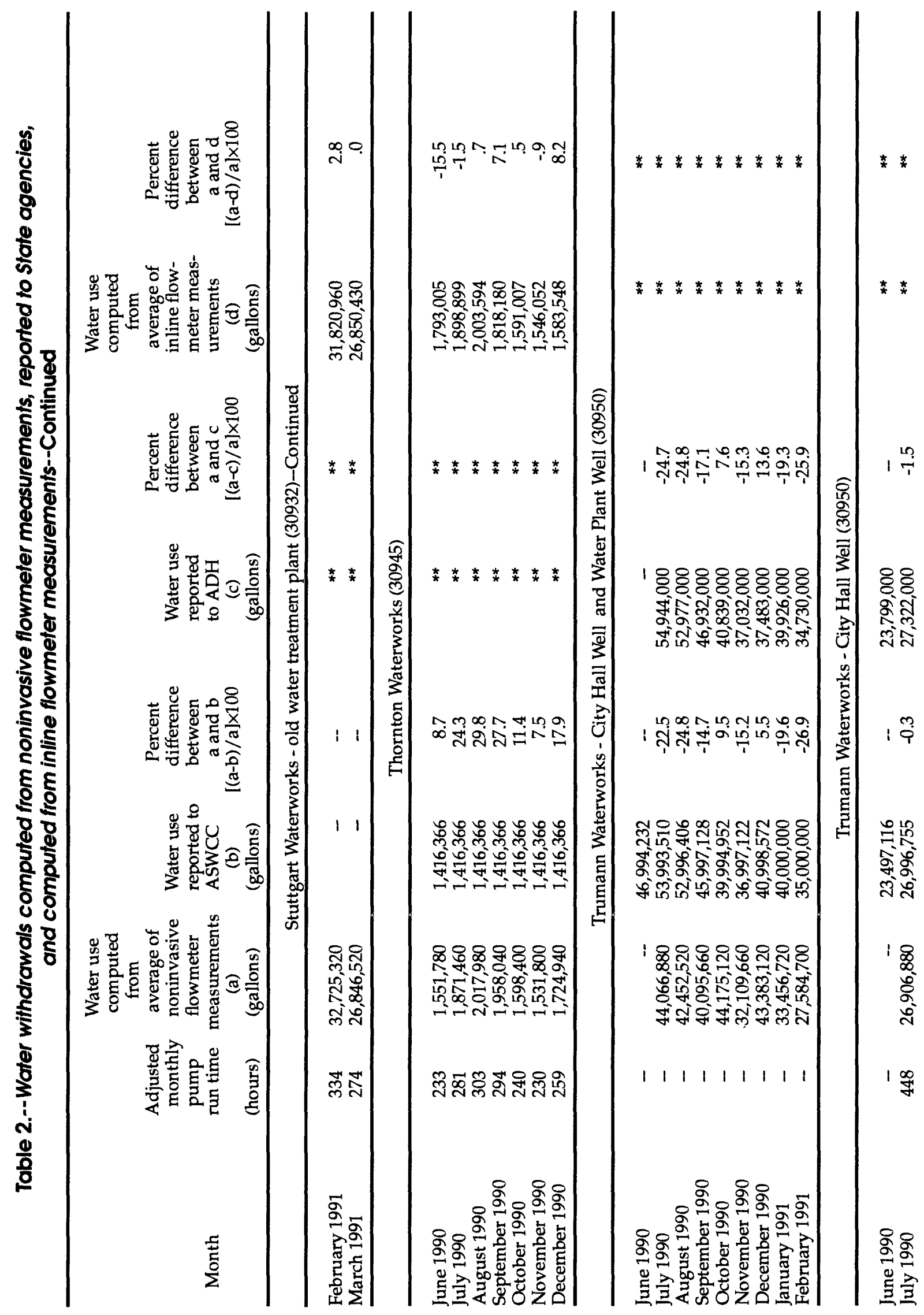




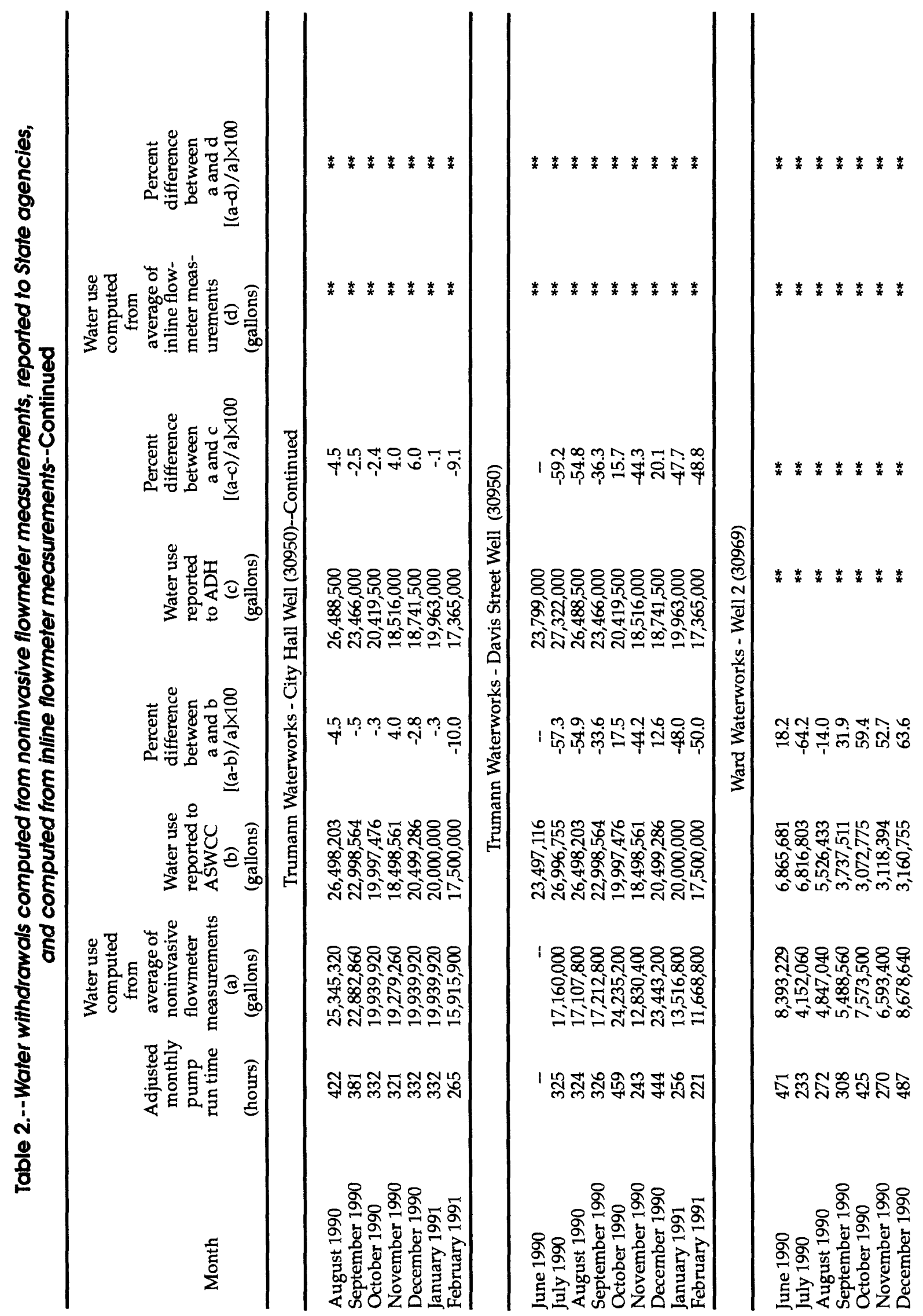




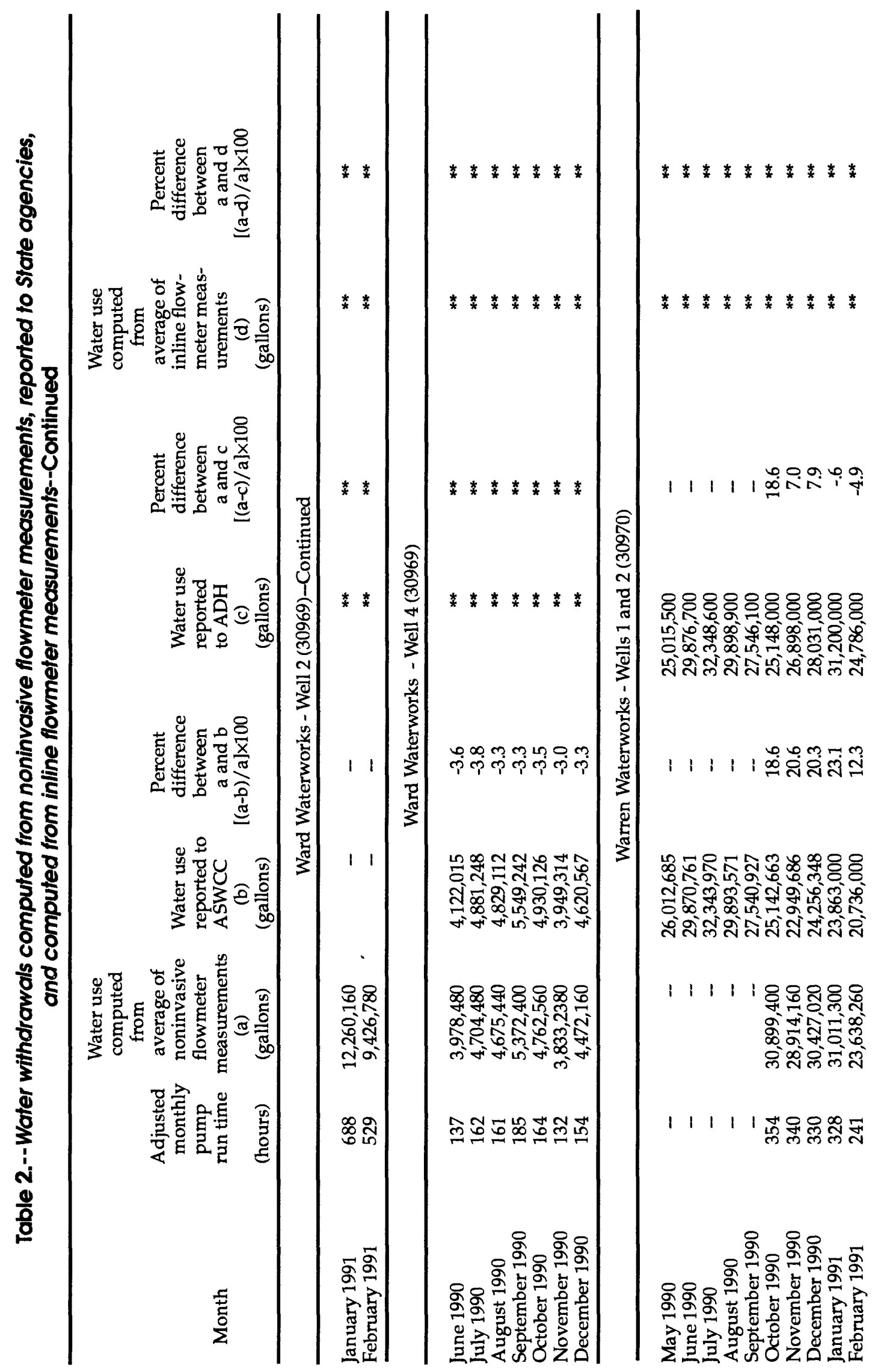




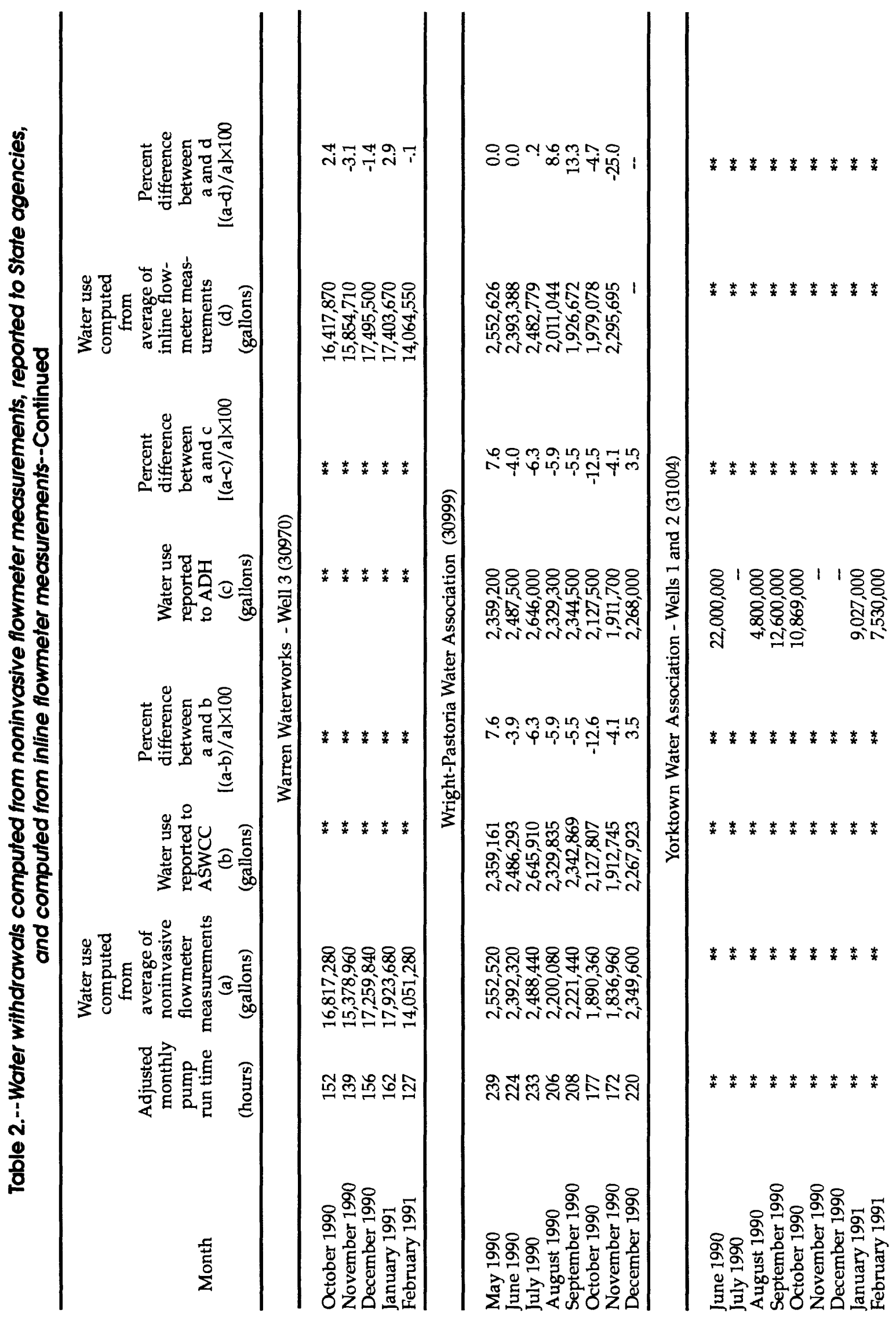




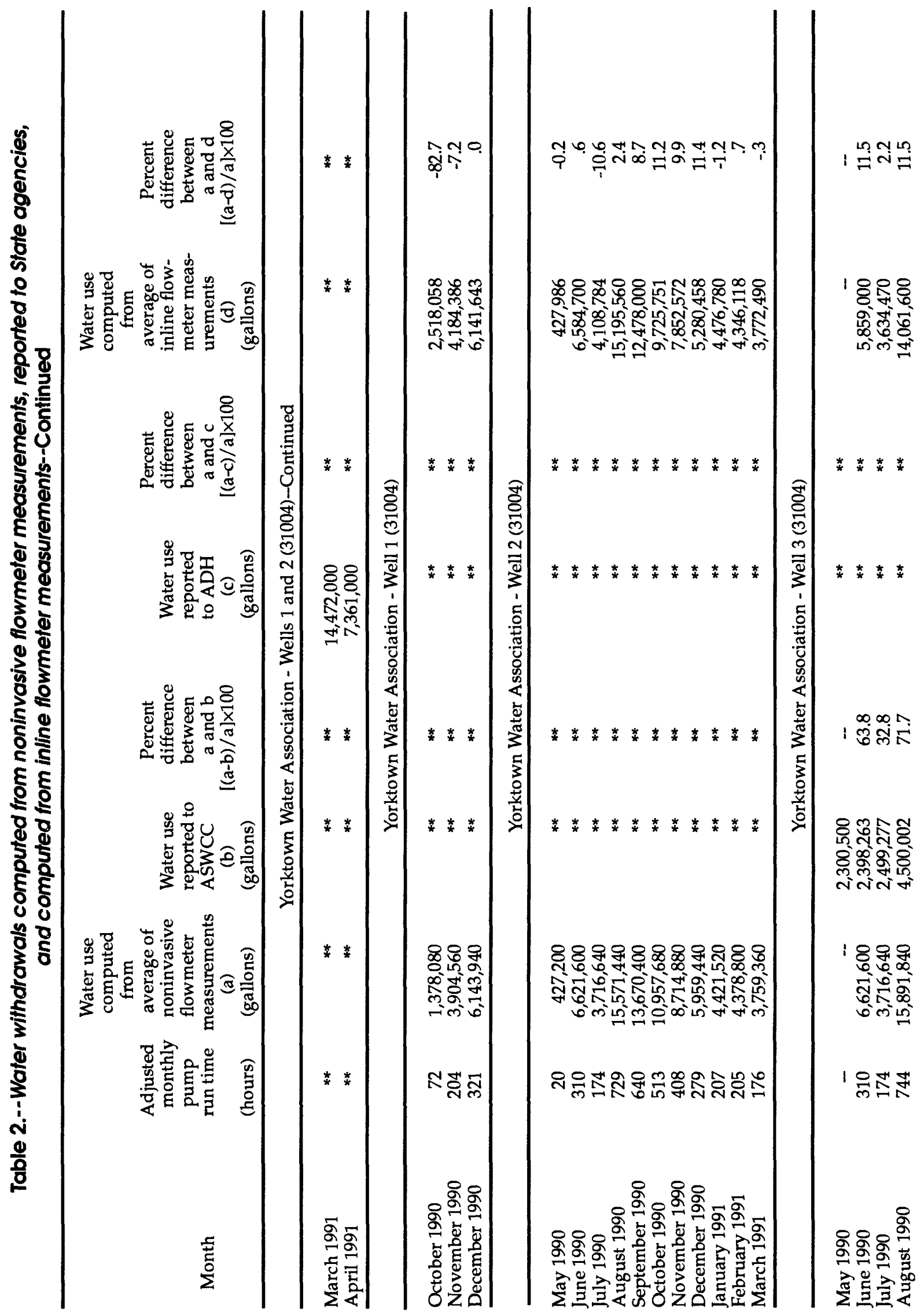




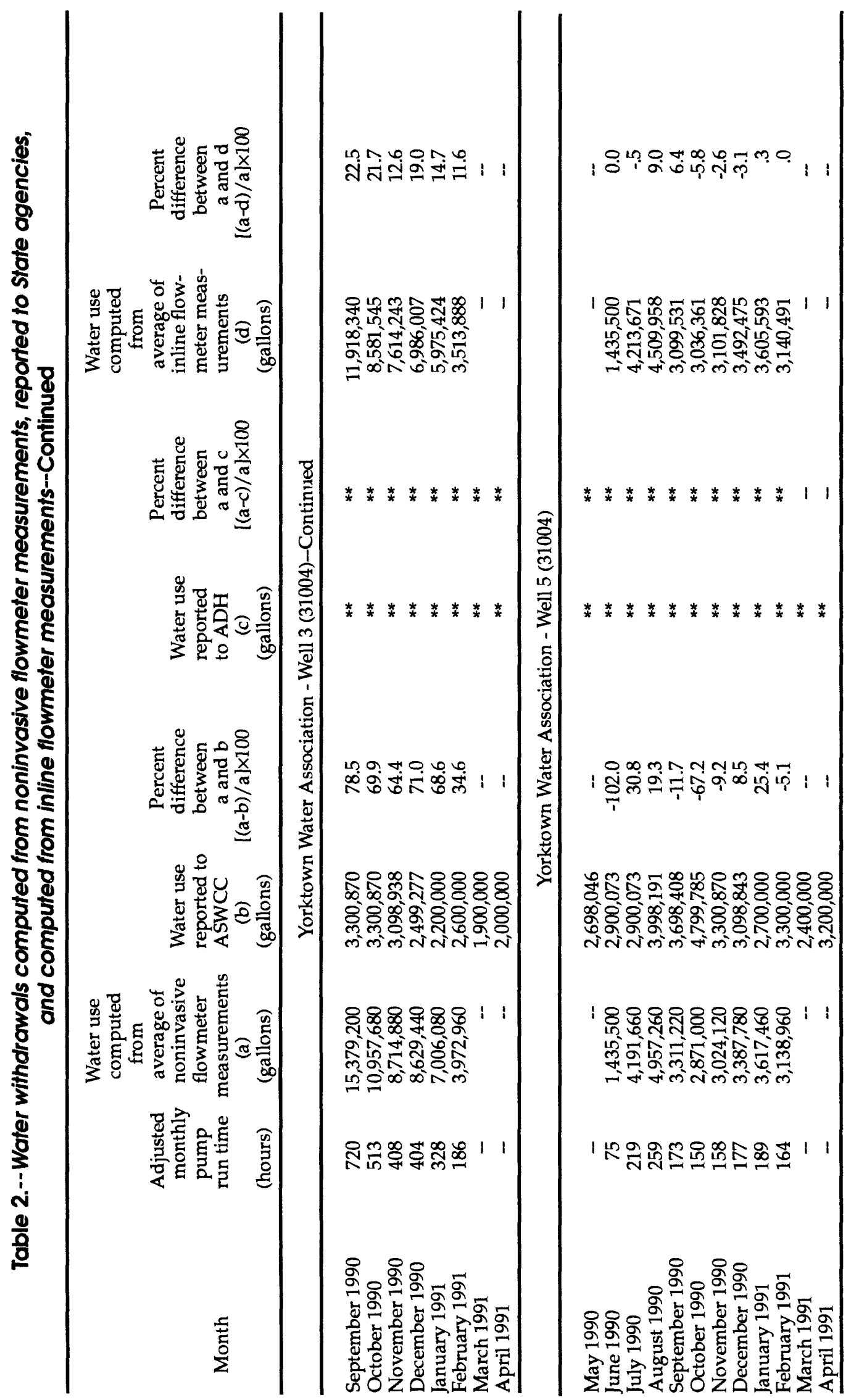


Table 3.--Flow data collected from public water-supply systems in Arkansas where record of pump running time was obtained from log books kept by the plant operator

Nalues were not rounded. ID, identification number; gal/min, gallons per minute; gal, gallons; -, no measurement; "", data not available)

\begin{tabular}{|c|c|c|c|c|c|}
\hline $\begin{array}{l}\text { Facility } \\
\text { name }\end{array}$ & $\begin{array}{l}\text { Facility } \\
\text { ID } \\
\text { (fig. 1) }\end{array}$ & $\begin{array}{l}\text { Measure- } \\
\text { ment } \\
\text { date }\end{array}$ & $\begin{array}{c}\text { Pipeflow measured } \\
\text { by noninvasive } \\
\text { flowmeter } \\
\text { (gal/min) }\end{array}$ & $\begin{array}{c}\text { Pipeflow } \\
\text { measured by } \\
\text { inline flowmeter } \\
\text { (gal/min) } \\
\end{array}$ & $\begin{array}{c}\text { Water flowing } \\
\text { through inline } \\
\text { flowmeter since } \\
\text { last visit } \\
\text { (gal) } \\
\end{array}$ \\
\hline Bigelow & 30551 & $\begin{array}{r}6-19-90 \\
7-31-90 \\
8-24-90 \\
9-13-90 \\
10-12-90 \\
11-28-90 \\
12-18-90 \\
1-22-91 \\
\text { Average }\end{array}$ & $\begin{array}{r}156 \\
-- \\
186 \\
185 \\
187 \\
203 \\
210 \\
\underline{210} \\
191\end{array}$ & $\begin{array}{r}160 \\
- \\
187 \\
200 \\
215 \\
205 \\
200 \\
\overline{--}\end{array}$ & $\begin{array}{r}-- \\
2,906,980 \\
1,302,434 \\
1,066,045 \\
1,472,600 \\
2,238,095 \\
951,920 \\
2,254,785 \\
* *\end{array}$ \\
\hline Big Flat & 30550 & $\begin{array}{r}7-17-90 \\
8-15-90 \\
9-25-90 \\
11-14-90 \\
12-12-90 \\
1-16-91 \\
2-21-91 \\
3-19-91 \\
\text { Average }\end{array}$ & $\begin{array}{l}181 \\
185 \\
190 \\
187 \\
192 \\
195 \\
164 \\
173 \\
183\end{array}$ & $\begin{array}{l}172 \\
180 \\
182 \\
177 \\
179 \\
183 \\
160 \\
170 \\
175\end{array}$ & $\begin{array}{r}-- \\
800,000 \\
908,800 \\
1,137,100 \\
837,900 \\
1,130,000 \\
540,400 \\
534,700 \\
* *\end{array}$ \\
\hline Calico Rock & 30576 & $\begin{array}{r}11-14-90 \\
12-12-90 \\
1-16-91 \\
2-14-91 \\
3-18-91 \\
6-04-91 \\
\text { Average }\end{array}$ & $\begin{array}{l}326 \\
330 \\
333 \\
331 \\
354 \\
\frac{320}{332}\end{array}$ & $\begin{array}{l}* * \\
* * \\
* * \\
* * \\
* * \\
* * \\
* *\end{array}$ & $\begin{array}{l}* * \\
* * \\
* * \\
* * \\
* * \\
* * \\
* *\end{array}$ \\
\hline Camden & 20600 & $\begin{array}{r}6-20-90 \\
7-25-90 \\
9-20-90 \\
10-14-90 \\
12-19-90 \\
3-26-91 \\
\text { Average }\end{array}$ & $\begin{array}{l}3,722 \\
4,311 \\
2,618 \\
3,154 \\
3,176 \\
\frac{3,295}{3,379}\end{array}$ & $\begin{array}{l}* * \\
* * \\
* * \\
* * \\
* * \\
* *\end{array}$ & $\begin{array}{r}-- \\
22,742,200 \\
68,634,000 \\
59,294,000 \\
139,009,000 \\
-\end{array}$ \\
\hline Carthage & 30582 & $\begin{array}{r}5-15-90 \\
7-26-90 \\
8-21-90 \\
9-13-90 \\
10-16-90 \\
11-27-90 \\
12-17-90 \\
1-29-91 \\
2-27-91 \\
3-29-91 \\
\text { Average }\end{array}$ & $\begin{array}{r}- \\
112 \\
140 \\
- \\
124 \\
119 \\
145 \\
126 \\
122 \\
\frac{122}{126}\end{array}$ & $\begin{array}{r}100 \\
120 \\
150 \\
- \\
120 \\
120 \\
150 \\
125 \\
130 \\
\frac{125}{12}\end{array}$ & $\begin{array}{r}- \\
4,745,030 \\
1,886,000 \\
1,803,000 \\
3,601,000 \\
3,198,160 \\
1,342,840 \\
1,950,850 \\
2,733,150 \\
18,732,210 \\
* *\end{array}$ \\
\hline
\end{tabular}


Table 3.--Flow data collected from public water-supply systems in Arkansas where record of pump running time was obtained from log books kept by the plant operator-Continued

\begin{tabular}{|c|c|c|c|c|c|}
\hline $\begin{array}{l}\text { Facility } \\
\text { name }\end{array}$ & $\begin{array}{l}\text { Facility } \\
\text { ID } \\
\text { (fig. 1) }\end{array}$ & $\begin{array}{l}\text { Measure- } \\
\text { ment } \\
\text { date }\end{array}$ & $\begin{array}{c}\text { Pipeflow measured } \\
\text { by noninvasive } \\
\text { flowmeter } \\
\text { (gal/min) }\end{array}$ & $\begin{array}{c}\text { Pipeflow } \\
\text { measured by } \\
\text { inline flowmeter } \\
\text { (gal/min) }\end{array}$ & $\begin{array}{c}\text { Water flowing } \\
\text { through inline } \\
\text { flowmeter since } \\
\text { last visit } \\
\text { (gal) } \\
\end{array}$ \\
\hline Cass & 30584 & $\begin{array}{r}7-16-90 \\
8-16-90 \\
9-28-90 \\
11-16-90 \\
12-07-90 \\
1-18-91 \\
2-20-91 \\
3-21-91 \\
\text { Average }\end{array}$ & $\begin{array}{l}42 \\
41 \\
42 \\
51 \\
51 \\
54 \\
54 \\
54 \\
49\end{array}$ & $\begin{array}{l}* * \\
* * \\
* * \\
* * \\
* * \\
55 \\
57 \\
-- \\
56\end{array}$ & $\begin{array}{r}* * \\
* * \\
* * \\
* * \\
* * \\
* * \\
2,845,670 \\
711,770 \\
* *\end{array}$ \\
\hline Dierks & 30631 & $\begin{array}{r}5-14-90 \\
6-18-90 \\
7-26-90 \\
9-21-90 \\
10-15-90 \\
11-26-90 \\
12-19-90 \\
1-23-91 \\
2-28-91 \\
3-25-91 \\
\text { Average }\end{array}$ & $\begin{array}{r}-- \\
\overline{-} \\
715 \\
734 \\
678 \\
599 \\
674 \\
\overline{-} \\
7 \overline{-}\end{array}$ & $\begin{array}{r}550 \\
850 \\
940 \\
720 \\
730 \\
675 \\
610 \\
670 \\
- \\
\overline{\overline{18}}\end{array}$ & $\begin{array}{r}- \\
12,761,200 \\
15,532,600 \\
52,059,800 \\
820,600 \\
14,105,000 \\
8,479,000 \\
12,285,400 \\
11,998,600 \\
8,523,700 \\
* *\end{array}$ \\
\hline Guy & 30693 & $\begin{array}{r}7-27-90 \\
8-24-90 \\
9-13-90 \\
11-29-90 \\
12-12-90 \\
1-14-91 \\
2-15-91 \\
3-14-91 \\
\text { Average }\end{array}$ & $\begin{array}{r}74 \\
93 \\
104 \\
36 \\
74 \\
72 \\
84 \\
100 \\
80\end{array}$ & $\begin{array}{r}72 \\
97 \\
103 \\
33 \\
88 \\
99 \\
92 \\
\frac{99}{85}\end{array}$ & $\begin{array}{r}- \\
2,411,530 \\
3,207,420 \\
914,760 \\
696,960 \\
2,465,100 \\
1,396,560 \\
1,740,420 \\
* *\end{array}$ \\
\hline Harrell & 30699 & $\begin{array}{r}7-24-90 \\
8-28-90 \\
9-17-90 \\
10-15-90 \\
11-19-90 \\
12-20-90 \\
1-24-91 \\
2-26-91 \\
3-27-91 \\
\text { Average }\end{array}$ & $\begin{array}{r}- \\
- \\
142 \\
142 \\
149 \\
147 \\
147 \\
- \\
\frac{150}{146}\end{array}$ & $\begin{array}{r}- \\
-- \\
150 \\
145 \\
152 \\
150 \\
150 \\
- \\
\frac{150}{150}\end{array}$ & $\begin{array}{r}-\overline{-} \\
957,500 \\
684,100 \\
597,500 \\
803,900 \\
718,700 \\
1,011,200 \\
841,800 \\
662,800 \\
* *\end{array}$ \\
\hline
\end{tabular}


Table 3.--Flow data collected from public water-supply systems in Arkansas where record of pump running time was obtained from log books kept by the plant operator--Continued

\begin{tabular}{|c|c|c|c|c|c|}
\hline $\begin{array}{l}\text { Facility } \\
\text { name }\end{array}$ & $\begin{array}{l}\text { Facility } \\
\text { ID } \\
\text { (fig. 1) }\end{array}$ & $\begin{array}{l}\text { Measure- } \\
\text { ment } \\
\text { date }\end{array}$ & $\begin{array}{l}\text { Pipeflow measured } \\
\text { by noninvasive } \\
\text { flowmeter } \\
\text { (gal/min) }\end{array}$ & $\begin{array}{c}\text { Pipeflow } \\
\text { measured by } \\
\text { inline flowmeter } \\
\text { (gal/min) }\end{array}$ & $\begin{array}{c}\text { Water flowing } \\
\text { through inline } \\
\text { flowmeter since } \\
\text { last visit } \\
\text { (gal) }\end{array}$ \\
\hline Haskell & 30702 & $\begin{array}{r}5-04-90 \\
6-19-90 \\
7-31-90 \\
8-21-90 \\
9-14-90 \\
10-12-90 \\
11-27-90 \\
12-18-90 \\
1-29-91 \\
\text { Average }\end{array}$ & $\begin{array}{l}151 \\
161 \\
107 \\
156 \\
115 \\
119 \\
122 \\
119 \\
\frac{177}{136}\end{array}$ & $\begin{array}{l}132 \\
140 \\
130 \\
140 \\
127 \\
129 \\
127 \\
125 \\
\frac{174}{136} \\
\end{array}$ & $\begin{array}{r}- \\
5,176,800 \\
3,512,400 \\
4,648,600 \\
3,174,800 \\
3,388,200 \\
6,034,700 \\
2,987,300 \\
7,033,400 \\
* *\end{array}$ \\
\hline Holly Grove & 30713 & $\begin{array}{r}6-21-90 \\
7-23-90 \\
8-27-90 \\
9-17-90 \\
10-17-90 \\
11-20-90 \\
12-21-90 \\
1-25-91 \\
\text { Average }\end{array}$ & $\begin{array}{r}468 \\
- \\
- \\
453 \\
526 \\
415 \\
493 \\
\frac{507}{477}\end{array}$ & $\begin{array}{r}475 \\
- \\
- \\
450 \\
500 \\
400 \\
500 \\
\frac{500}{471}\end{array}$ & $\begin{array}{r}- \\
7,474,000 \\
6,221,000 \\
1,874,000 \\
5,499,000 \\
5,733,000 \\
5,410,000 \\
6,969,000 \\
* *\end{array}$ \\
\hline Huntsville & 30723 & $\begin{array}{r}6-14-90 \\
7-19-90 \\
8-15-90 \\
9-27-90 \\
11-15-90 \\
12-06-90 \\
1-17-91 \\
2-20-91 \\
3-20-91 \\
\text { Average }\end{array}$ & $\begin{array}{r}916 \\
945 \\
920 \\
1,073 \\
944 \\
968 \\
998 \\
989 \\
- \\
969\end{array}$ & $\begin{array}{l}930 \\
910 \\
900 \\
925 \\
920 \\
940 \\
950 \\
950 \\
\underline{960} \\
932\end{array}$ & $\begin{array}{r}- \\
38,346,000 \\
28,358,000 \\
44,673,000 \\
55,142,000 \\
20,759,000 \\
48,686,000 \\
41,897,500 \\
33,041,500 \\
*\end{array}$ \\
\hline Marianna & 30778 & $\begin{array}{r}9-17-90 \\
10-17-90 \\
11-19-90 \\
12-20-90 \\
1-25-91 \\
2-25-91 \\
\text { Average }\end{array}$ & $\begin{array}{l}1,229 \\
1,242 \\
1,303 \\
1,261 \\
1,278 \\
1,292 \\
1,268\end{array}$ & $\begin{array}{l}* * \\
* * \\
* * \\
* * \\
* * \\
* *\end{array}$ & $\begin{array}{l}* * \\
* * \\
* * \\
* * \\
* * \\
* * \\
* *\end{array}$ \\
\hline $\begin{array}{l}\text { Perryville } \\
\text { Wells } 1 \text { and } 2\end{array}$ & 30859 & $\begin{array}{r}6-01-90 \\
6-19-90 \\
7-31-90 \\
8-24-90 \\
9-14-90 \\
10-12-90 \\
11-28-90 \\
12-17-90 \\
1-22-91 \\
\text { Average }\end{array}$ & $\begin{array}{l}372 \\
407 \\
455 \\
535 \\
597 \\
435 \\
487 \\
567 \\
\frac{471}{493}\end{array}$ & $\begin{array}{r}- \\
- \\
-- \\
525 \\
555 \\
400 \\
475 \\
550 \\
\frac{455}{* *}\end{array}$ & $\begin{array}{r}- \\
- \\
1,358,000 \\
13,731,000 \\
10,899,000 \\
10.289,000 \\
14,729,000 \\
6,141,000 \\
14,166,000 \\
* *\end{array}$ \\
\hline
\end{tabular}


Table 3.--Flow data collected from public water-supply systems in Arkansas where record of pump running time was obtained from log books kept by the plant operator--Continued

\begin{tabular}{|c|c|c|c|c|c|}
\hline $\begin{array}{l}\text { Facility } \\
\text { name }\end{array}$ & $\begin{array}{l}\text { Facility } \\
\text { ID } \\
\text { (fig. 1) }\end{array}$ & $\begin{array}{l}\text { Measure- } \\
\text { ment } \\
\text { date }\end{array}$ & $\begin{array}{l}\text { Pipeflow measured } \\
\text { by noninvasive } \\
\text { flowmeter } \\
\text { (gal } / \mathrm{min})\end{array}$ & $\begin{array}{c}\text { Pipeflow } \\
\text { measured by } \\
\text { inline flowmeter } \\
\text { (gal/min) }\end{array}$ & $\begin{array}{l}\text { Water flowing } \\
\text { through inline } \\
\text { flowmeter since } \\
\text { last visit } \\
\text { (gal) }\end{array}$ \\
\hline $\begin{array}{l}\text { Prairie Grove } \\
\text { Wells } 1 \text { and } 2\end{array}$ & 30871 & $\begin{array}{r}6-14-90 \\
7-10-90 \\
8-16-90 \\
9-27-90 \\
11-15-90 \\
12-06-90 \\
1-17-91 \\
\text { Average }\end{array}$ & $\begin{array}{l}396 \\
453 \\
455 \\
476 \\
472 \\
485 \\
\frac{472}{458}\end{array}$ & $\begin{array}{r}- \\
458 \\
458 \\
440 \\
440 \\
440 \\
\frac{480}{453}\end{array}$ & $\begin{array}{l}* * \\
* * \\
* * \\
* * \\
* * \\
* * \\
* * \\
* *\end{array}$ \\
\hline Roe & 30894 & $\begin{array}{r}6-21-90 \\
8-27-90 \\
9-17-90 \\
10-17-90 \\
11-20-90 \\
12-21-90 \\
1-25-91 \\
2-25-91 \\
3-27-91 \\
\text { Average }\end{array}$ & $\begin{array}{r}192 \\
- \\
198 \\
155 \\
181 \\
186 \\
182 \\
- \\
\frac{186}{183}\end{array}$ & $\begin{array}{r}180 \\
- \\
180 \\
150 \\
180 \\
180 \\
180 \\
-- \\
\frac{180}{176}\end{array}$ & $\begin{array}{r}- \\
1,315,900 \\
522,100 \\
488,100 \\
511,000 \\
461,322 \\
728,858 \\
513,220 \\
454,850 \\
* *\end{array}$ \\
\hline Stamps & 30926 & $\begin{array}{r}6-18-90 \\
7-25-90 \\
8-29-90 \\
9-19-90 \\
10-15-90 \\
11-26-90 \\
12-19-90 \\
1-23-91 \\
\text { Average }\end{array}$ & $\begin{array}{r}644 \\
-- \\
599 \\
647 \\
645 \\
611 \\
647 \\
\frac{659}{636}\end{array}$ & $\begin{array}{r}630 \\
-- \\
640 \\
630 \\
620 \\
625 \\
655 \\
\frac{650}{636}\end{array}$ & $\begin{array}{r}- \\
18,779,825 \\
17,738,545 \\
9,791,930 \\
9,484,392 \\
14,660,678 \\
8,156,500 \\
14,102,450 \\
* *\end{array}$ \\
\hline Stamps & 30926 & $\begin{array}{r}6-18-90 \\
7-25-90 \\
8-29-90 \\
9-19-90 \\
10-15-90 \\
11-26-90 \\
12-19-90 \\
1-23-91 \\
\text { Average }\end{array}$ & $\begin{array}{r}644 \\
-- \\
599 \\
647 \\
645 \\
611 \\
647 \\
\frac{659}{636}\end{array}$ & $\begin{array}{r}630 \\
-- \\
640 \\
630 \\
620 \\
625 \\
655 \\
\frac{650}{636}\end{array}$ & $\begin{array}{r}- \\
18,779,825 \\
17,738,545 \\
9,791,930 \\
9,484,392 \\
14,660,678 \\
8,156,500 \\
14,102,450 \\
* *\end{array}$ \\
\hline $\begin{array}{l}\text { Stuttgart } \\
\text { (new water } \\
\text { treatment } \\
\text { plant) }\end{array}$ & 30932 & $\begin{array}{r}5-17-90 \\
6-22-90 \\
7-23-90 \\
8-27-90 \\
9-17-90 \\
10-17-90 \\
11-20-90 \\
12-21-90 \\
1-25-91 \\
2-25-91 \\
3-27-91 \\
\text { Average }\end{array}$ & $\begin{array}{l}-- \\
1,294 \\
1,615 \\
1,358 \\
1,486 \\
1,632 \\
1,700 \\
1,483 \\
1,592 \\
1,659 \\
1,535 \\
1,535\end{array}$ & $\begin{array}{l}3,000 \\
3,000 \\
1,680 \\
3,648 \\
1,475 \\
1,650 \\
1,700 \\
1,450 \\
1,715 \\
1,700 \\
2,102 \\
2,102\end{array}$ & $\begin{array}{r}- \\
69,852,000 \\
63,221,000 \\
88,803,000 \\
55,742,000 \\
50,581,000 \\
66,996,000 \\
52,796,000 \\
103,089,000 \\
37,211,000 \\
67,957,000 \\
* *\end{array}$ \\
\hline
\end{tabular}


Table 3.--Flow data collected from public water-supply systems in Arkansas where record of pump running time was obtained from log books kept by the plant operator--Continued

\begin{tabular}{|c|c|c|c|c|c|}
\hline $\begin{array}{l}\text { Facility } \\
\text { name }\end{array}$ & $\begin{array}{l}\text { Facility } \\
\text { ID } \\
\text { (fig. 1) }\end{array}$ & $\begin{array}{l}\text { Measure- } \\
\text { ment } \\
\text { date }\end{array}$ & $\begin{array}{c}\text { Pipeflow measured } \\
\text { by noninvasive } \\
\text { flowmeter } \\
\text { (gal/min) }\end{array}$ & $\begin{array}{c}\text { Pipeflow } \\
\text { measured by } \\
\text { inline flowmeter } \\
\text { (gal/min) }\end{array}$ & $\begin{array}{c}\text { Water flowing } \\
\text { through inline } \\
\text { flowmeter since } \\
\text { last visit } \\
\text { (gal) }\end{array}$ \\
\hline $\begin{array}{l}\text { Stuttgart } \\
\text { (old water } \\
\text { treatment } \\
\text { plant) }\end{array}$ & 30932 & $\begin{array}{r}5-17-90 \\
6-22-90 \\
7-23-90 \\
8-27-90 \\
9-17-90 \\
10-17-90 \\
11-20-90 \\
12-21-90 \\
1-26-91 \\
2-25-91 \\
3-27-91 \\
\text { Average }\end{array}$ & $\begin{array}{r}-\overline{2,727} \\
1,957 \\
1,935 \\
1,767 \\
1,534 \\
1,805 \\
931 \\
1,757 \\
935 \\
984 \\
1,633\end{array}$ & $\begin{array}{r}2,200 \\
2,425 \\
1,760 \\
1,600 \\
1,750 \\
1,575 \\
1,800 \\
925 \\
1,790 \\
950 \\
975 \\
1,614\end{array}$ & $\begin{array}{r}58,614,500 \\
68,220,000 \\
68.226 .500 \\
45,045,100 \\
51,384,900 \\
52,932,600 \\
48,467,500 \\
53,713,800 \\
35,623,900 \\
28,891,300 \\
*\end{array}$ \\
\hline Thornton & 30945 & $\begin{array}{r}6-02-90 \\
7-25-90 \\
8-24-90 \\
9-19-90 \\
10-16-90 \\
11-27-90 \\
12-20-90 \\
1-24-91 \\
\text { Average }\end{array}$ & $\begin{array}{r}114 \\
- \\
118 \\
115 \\
107 \\
111 \\
107 \\
\frac{106}{111}\end{array}$ & $\begin{array}{r}110 \\
- \\
97 \\
100 \\
100 \\
100 \\
105 \\
\frac{110}{103}\end{array}$ & $\begin{array}{r}- \\
2,127,050 \\
4,762,500 \\
2,682,310 \\
1,485,410 \\
1,937,380 \\
1,026,400 \\
20,074,780 \\
* *\end{array}$ \\
\hline $\begin{array}{l}\text { Warren } \\
\text { Wells } 1 \text { and } 2\end{array}$ & 30970 & $\begin{array}{r}5-15-90 \\
6-18-90 \\
7-24-90 \\
8-28-90 \\
9-20-90 \\
10-18-90 \\
11-19-90 \\
12-20-90 \\
1-29-91 \\
2-26-91 \\
3-26-91 \\
\text { Average }\end{array}$ & $\begin{array}{r}\overline{-} \\
602 \\
\overline{2} \\
692 \\
\overline{-} \\
\overline{-} \\
694 \\
\overline{-} \\
\frac{663}{663}\end{array}$ & $\begin{array}{l}* * \\
* * \\
* * \\
* * \\
* * \\
* * \\
* * \\
* * \\
* * \\
* * \\
* * \\
* *\end{array}$ & $\begin{array}{r}- \\
3,007,250 \\
30,228,500 \\
30,228,500 \\
20,101,000 \\
23,178,700 \\
24,872,600 \\
22,956,000 \\
27,502,000 \\
24,474,000 \\
20,405,500 \\
* *\end{array}$ \\
\hline $\begin{array}{l}\text { Warren } \\
\text { Well } 3\end{array}$ & 30970 & $\begin{array}{r}5-15-90 \\
6-18-90 \\
7-24-90 \\
8-28-90 \\
9-20-90 \\
10-18-90 \\
11-19-90 \\
12-20-90 \\
1-29-91 \\
2-26-91 \\
3-26-91 \\
\text { Average }\end{array}$ & $\begin{array}{r}- \\
1,650 \\
- \\
- \\
- \\
1,726 \\
1,733 \\
1,703 \\
2,096 \\
2,153 \\
1,844 \\
1,844\end{array}$ & $\begin{array}{r}- \\
- \\
- \\
- \\
1,730 \\
1,730 \\
1,720 \\
2,145 \\
2,220 \\
1,909 \\
1,909\end{array}$ & $\begin{array}{r}- \\
- \\
- \\
- \\
377,900 \\
108,900 \\
339,700 \\
456,300 \\
122,700 \\
512,300 \\
* *\end{array}$ \\
\hline
\end{tabular}


Table 3.--Flow data collected from public water-supply systems in Arkansas where record of pump running time was obtained from log books kept by the plant operator--Continued

\begin{tabular}{|c|c|c|c|c|c|}
\hline $\begin{array}{l}\text { Facility } \\
\text { name }\end{array}$ & $\begin{array}{l}\text { Facility } \\
\text { ID } \\
\text { (fig. 1) }\end{array}$ & $\begin{array}{l}\text { Measure- } \\
\text { ment } \\
\text { date }\end{array}$ & $\begin{array}{l}\text { Pipeflow measured } \\
\text { by noninvasive } \\
\text { flowmeter } \\
\text { (gal/min) }\end{array}$ & $\begin{array}{c}\text { Pipeflow } \\
\text { measured by } \\
\text { inline flowmeter } \\
(\mathrm{gal} / \mathrm{min})\end{array}$ & $\begin{array}{l}\text { Water flowing } \\
\text { through inline } \\
\text { flowmeter since } \\
\text { last visit } \\
\text { (gal) }\end{array}$ \\
\hline \multirow[t]{9}{*}{ Wright-Pastoria } & 30999 & $5-31-90$ & 179 & 185 & - \\
\hline & & $7-30-90$ & - & - & 506,620 \\
\hline & & $8-22-90$ & 156 & 189 & 170,910 \\
\hline & & $9-17-90$ & 180 & 188 & 213,930 \\
\hline & & $10-11-90$ & 192 & 200 & 172,290 \\
\hline & & $11-21-90$ & 188 & 185 & 266,490 \\
\hline & & $12-18-90$ & 170 & 172 & 172,930 \\
\hline & & $1-28-91$ & $\underline{185}$ & 182 & 311,900 \\
\hline & & Average & $\overline{179}$ & 186 & $* *$ \\
\hline
\end{tabular}


Table 4. --Flow data collected from public water-supply systems in Arkansas where record of pump running time was defermined from either electric energy consumption or vibration fime totalizer

The numeric values in table are presented as reported or measured. ID, identification number; h/d, hours per day; gal/ min, gallons per minute; gal, gallons; -, no measurement; "* data not available: NA, not applicable)

\begin{tabular}{|c|c|c|c|c|c|c|c|c|}
\hline $\begin{array}{l}\text { Facility } \\
\text { name }\end{array}$ & $\begin{array}{l}\text { Facility } \\
\text { ID } \\
\text { (fig.1) }\end{array}$ & $\begin{array}{l}\text { Measure- } \\
\text { ment } \\
\text { date }\end{array}$ & $\begin{array}{l}\text { Pump } \\
\text { running } \\
\text { time } \\
\text { since } \\
\text { last } \\
\text { meas- } \\
\text { urement } \\
\text { (days) }\end{array}$ & $\begin{array}{l}\text { Pump } \\
\text { running } \\
\text { time } \\
\text { since } \\
\text { last } \\
\text { meas- } \\
\text { urement } \\
\text { (hours) }\end{array}$ & $\begin{array}{l}\text { Average } \\
\text { pumping } \\
\text { rate for } \\
\text { period of } \\
\text { time since } \\
\text { last meas- } \\
\text { urement } \\
\text { (h/d) }\end{array}$ & $\begin{array}{l}\text { Pipeflow } \\
\text { measured } \\
\text { by nonin- } \\
\text { vasive flow- } \\
\text { meter } \\
(\mathrm{gal} / \mathrm{min})\end{array}$ & $\begin{array}{l}\text { Pipeflow } \\
\text { meas- } \\
\text { sured } \\
\text { by inline } \\
\text { flowmeter } \\
\text { (gal/min) }\end{array}$ & $\begin{array}{l}\text { Water } \\
\text { flowing } \\
\text { through in- } \\
\text { line flow- } \\
\text { meter since } \\
\text { last meas- } \\
\text { urement } \\
\text { (gal) }\end{array}$ \\
\hline \multirow{8}{*}{$\begin{array}{c}\text { Arkansas } \\
\text { City }\end{array}$} & \multirow{8}{*}{30523} & $6-21-90$ & - & - & - & - & $* *$ & $* *$ \\
\hline & & $7-24-90$ & 33 & 335 & 10.1 & 231 & ** & $* *$ \\
\hline & & $8-28-90$ & 35 & 165 & 4.7 & 242 & ** & ** \\
\hline & & $9-18-90$ & 21 & 174 & 8.3 & 247 & $* *$ & $* *$ \\
\hline & & $10-18-90$ & 30 & 190 & 6.3 & 238 & ** & ** \\
\hline & & $11-19-90$ & 32 & 203 & 6.3 & 224 & ** & ** \\
\hline & & $1-24-91$ & 66 & 590 & 8.9 & $\underline{236}$ & $* *$ & $* *$ \\
\hline & & Average & NA & NA & NA & 236 & NA & NA \\
\hline \multirow{10}{*}{$\begin{array}{r}\text { Bennett } \\
\text { Acres }\end{array}$} & \multirow[t]{10}{*}{30543} & $7-13-90$ & - & - & - & - & $* *$ & $* *$ \\
\hline & & $8-21-90$ & 39 & 223 & 5.7 & 11 & ** & ** \\
\hline & & $9-12-90$ & 22 & 149 & 6.8 & 12 & $* *$ & $* *$ \\
\hline & & $10-10-90$ & 28 & 186 & 6.6 & 12 & $* *$ & $* *$ \\
\hline & & $11-28-90$ & 49 & 283 & 5.8 & 12 & ** & $* *$ \\
\hline & & $12-18-90$ & 20 & 119 & 5.9 & 12 & $* *$ & $* *$ \\
\hline & & $1-29-91$ & 42 & 367 & 8.7 & 12 & ** & $* *$ \\
\hline & & $2-22-91$ & 24 & 143 & 6.0 & 11 & ** & $* *$ \\
\hline & & $3-29-91$ & 35 & 237 & 6.8 & 12 & ** & $* *$ \\
\hline & & Average & NA & NA & NA & $\frac{12}{12}$ & NA & NA \\
\hline \multirow[t]{9}{*}{ Bergman } & \multirow[t]{9}{*}{30547} & $7-18-90$ & - & - & - & 97 & 95 & -- \\
\hline & & $8-15-90$ & 28 & 283 & 10.1 & 86 & 88 & $1,493,000$ \\
\hline & & $9-27-90$ & 43 & 480 & 11.2 & 98 & 96 & $2,540,000$ \\
\hline & & $11-15-90$ & 49 & 441 & 9.0 & 96 & 88 & $2,291,000$ \\
\hline & & $12-06-90$ & 21 & 174 & 8.3 & 85 & 80 & 935,000 \\
\hline & & $1-17-91$ & 42 & 385 & 9.2 & 92 & 88 & $2,047,000$ \\
\hline & & $2-21-91$ & 35 & 318 & 9.1 & 96 & 90 & $1,688,000$ \\
\hline & & $3-20-91$ & 27 & 234 & 8.7 & 93 & 89 & $1,246,000$ \\
\hline & & Average & NA & $\mathrm{NA}$ & NA & 93 & 89 & NA \\
\hline \multirow{12}{*}{$\begin{array}{l}\text { Black } \\
\text { Rock }\end{array}$} & \multirow[t]{12}{*}{30556} & $5-08-90$ & - & - & - & - & - & $* *$ \\
\hline & & $6-12-90$ & 35 & 219 & 6.3 & - & - & $* *$ \\
\hline & & $7-16-90$ & 34 & 377 & 11.1 & - & _- & $* *$ \\
\hline & & $8-14-90$ & 29 & 219 & 7.5 & - & - & ** \\
\hline & & $9-25-90$ & 42 & 336 & 8.0 & 227 & 246 & $* *$ \\
\hline & & $11-14-90$ & 50 & 388 & 7.8 & 222 & 246 & $* *$ \\
\hline & & $12-12-90$ & 28 & 195 & 7.0 & 220 & 246 & ** \\
\hline & & $1-16-91$ & 35 & 336 & 9.6 & 222 & 246 & $* *$ \\
\hline & & $2-13-91$ & 29 & 255 & 9.1 & 222 & 246 & ** \\
\hline & & 3-19-91 & 33 & 268 & 8.1 & 238 & 246 & ** \\
\hline & & $6-03-91$ & 76 & 558 & 7.3 & 226 & 246 & ** \\
\hline & & Average & NA & NA & $\mathrm{NA}$ & $\overline{225}$ & 246 & NA \\
\hline
\end{tabular}


Table 4.--Flow data collected from public water-supply systems in Arkansas where record of pump running time was determined from either electric energy consumption or vlbration time fotalizer--Continued

\begin{tabular}{|c|c|c|c|c|c|c|c|c|}
\hline $\begin{array}{l}\text { Facility } \\
\text { name }\end{array}$ & $\begin{array}{c}\text { Facility } \\
\text { ID } \\
\text { (fig. 1) } \\
\end{array}$ & $\begin{array}{l}\text { Measure- } \\
\text { ment } \\
\text { date }\end{array}$ & $\begin{array}{c}\text { Pump } \\
\text { running } \\
\text { time } \\
\text { since } \\
\text { last } \\
\text { meas- } \\
\text { urement } \\
\text { (days) } \\
\end{array}$ & $\begin{array}{l}\text { Pump } \\
\text { running } \\
\text { time } \\
\text { since } \\
\text { last } \\
\text { meas- } \\
\text { urement } \\
\text { (hours) }\end{array}$ & $\begin{array}{l}\text { Average } \\
\text { pumping } \\
\text { rate for } \\
\text { period of } \\
\text { time since } \\
\text { last meas- } \\
\text { urement } \\
(\mathrm{h} / \mathrm{d}) \\
\end{array}$ & $\begin{array}{l}\text { Pipeflow } \\
\text { measured } \\
\text { by nonin- } \\
\text { vasive flow- } \\
\text { meter } \\
\text { (gal/min) } \\
\end{array}$ & $\begin{array}{l}\text { Pipeflow } \\
\text { meas- } \\
\text { sured } \\
\text { by inline } \\
\text { flowmeter } \\
\text { (gal/min) } \\
\end{array}$ & $\begin{array}{l}\text { Water } \\
\text { flowing } \\
\text { through in- } \\
\text { line flow- } \\
\text { meter since } \\
\text { last meas- } \\
\text { urement } \\
\text { (gal) }\end{array}$ \\
\hline Collins & 30596 & $\begin{array}{r}8-28-90 \\
9-17-90 \\
10-18-90 \\
11-19-90 \\
12-20-90 \\
1-24-91 \\
3-26-91 \\
\text { Average }\end{array}$ & $\begin{array}{r}- \\
20 \\
31 \\
32 \\
31 \\
35 \\
61 \\
\text { NA }\end{array}$ & $\begin{array}{r}- \\
- \\
96 \\
77 \\
- \\
208 \\
152 \\
\text { NA }\end{array}$ & $\begin{array}{c}- \\
\overline{3} \\
3.1 \\
2.4 \\
\overline{5} \\
5.9 \\
5.4 \\
\text { NA }\end{array}$ & $\begin{array}{r}- \\
121 \\
150 \\
155 \\
154 \\
162 \\
148 \\
148\end{array}$ & $\begin{array}{l}150 \\
129 \\
150 \\
157 \\
157 \\
165 \\
\underline{151} \\
151\end{array}$ & $\begin{array}{r}- \\
425,700 \\
526,100 \\
494,625 \\
505,308 \\
630,774 \\
928,458 \\
\text { NA }\end{array}$ \\
\hline Franklin & 30666 & $\begin{array}{r}5-08-90 \\
6-12-90 \\
7-17-90 \\
8-14-90 \\
9-25-90 \\
11-14-90 \\
12-12-90 \\
1-16-91 \\
2-14-91 \\
3-19-91 \\
6-04-91 \\
\text { Average }\end{array}$ & $\begin{array}{r}- \\
35 \\
35 \\
28 \\
42 \\
50 \\
28 \\
35 \\
29 \\
33 \\
77 \\
\text { NA }\end{array}$ & $\begin{array}{r}- \\
- \\
- \\
74 \\
156 \\
156 \\
148 \\
125 \\
108 \\
123 \\
278 \\
\text { NA }\end{array}$ & $\begin{array}{c}\overline{-} \\
\overline{-} \\
2.6 \\
6.4 \\
3.1 \\
5.3 \\
3.6 \\
3.7 \\
3.7 \\
\overline{\mathrm{NA}}\end{array}$ & $\begin{array}{l}- \\
- \\
- \\
- \\
75 \\
72 \\
81 \\
84 \\
85 \\
80 \\
80 \\
80\end{array}$ & $\begin{array}{l}75 \\
- \\
- \\
- \\
75 \\
73 \\
83 \\
81 \\
80 \\
83 \\
\frac{79}{79}\end{array}$ & $\begin{array}{r}- \\
- \\
- \\
383,800 \\
769,200 \\
788,700 \\
684,000 \\
476,000 \\
475,400 \\
562,300 \\
1,444,500 \\
\text { NA }\end{array}$ \\
\hline Gilmore & 30676 & $\begin{array}{r}5-07-90 \\
6-11-90 \\
7-16-90 \\
8-13-90 \\
9-24-90 \\
11-13-90 \\
12-11-90 \\
1-15-91 \\
2-13-91 \\
3-18-91 \\
\text { Average }\end{array}$ & $\begin{array}{r}- \\
35 \\
35 \\
28 \\
42 \\
50 \\
28 \\
35 \\
29 \\
33 \\
\text { NA }\end{array}$ & $\begin{array}{r}- \\
46 \\
44 \\
35 \\
54 \\
64 \\
39 \\
88 \\
121 \\
74 \\
\text { NA }\end{array}$ & $\begin{array}{c}- \\
1.3 \\
1.3 \\
1.2 \\
1.3 \\
1.3 \\
1.4 \\
2.5 \\
4.2 \\
2.2 \\
\text { NA }\end{array}$ & $\begin{array}{r}- \\
289 \\
285 \\
288 \\
- \\
290 \\
- \\
291 \\
295 \\
\underline{290} \\
290\end{array}$ & $\begin{array}{r}- \\
300 \\
295 \\
300 \\
- \\
300 \\
- \\
300 \\
300 \\
\frac{299}{299}\end{array}$ & $\begin{array}{r}- \\
- \\
2,516,340 \\
2,077,650 \\
- \\
585,940 \\
- \\
- \\
2,602,800 \\
1,791,440 \\
\mathrm{NA}\end{array}$ \\
\hline $\begin{array}{l}\text { Green } \\
\text { Forest }\end{array}$ & 30686 & $\begin{array}{r}7-19-90 \\
8-15-90 \\
9-26-90 \\
11-15-90 \\
12-06-90 \\
1-17-91 \\
2-20-91 \\
3-20-91 \\
\text { Average }\end{array}$ & $\begin{array}{r}- \\
27 \\
42 \\
50 \\
21 \\
42 \\
34 \\
28 \\
\text { NA }\end{array}$ & $\begin{array}{r}- \\
530 \\
537 \\
909 \\
349 \\
693 \\
565 \\
463 \\
\text { NA }\end{array}$ & $\begin{array}{c}-\overline{19.6} \\
12.8 \\
18.2 \\
16.6 \\
16.5 \\
16.6 \\
16.5 \\
\text { NA }\end{array}$ & $\begin{array}{r}- \\
833 \\
848 \\
832 \\
851 \\
848 \\
857 \\
845 \\
845\end{array}$ & $\begin{array}{r}- \\
850 \\
850 \\
850 \\
850 \\
850 \\
850 \\
\underline{850} \\
850\end{array}$ & $\begin{array}{l}* * \\
* * \\
* * \\
* * \\
* * \\
* * \\
* * \\
* * \\
\text { NA }\end{array}$ \\
\hline
\end{tabular}


Table 4. --Flow data collected from publlc water-supply systems in Arkansas where record of pump running time was determined from either electric energy consumption or vibration time fotalizer--Confinued

\begin{tabular}{|c|c|c|c|c|c|c|c|c|}
\hline $\begin{array}{c}\text { Facility } \\
\text { name }\end{array}$ & $\begin{array}{c}\text { Facility } \\
\text { ID } \\
\text { (fig. 1) }\end{array}$ & $\begin{array}{l}\text { Measure- } \\
\text { ment } \\
\text { date }\end{array}$ & $\begin{array}{l}\text { Pump } \\
\text { running } \\
\text { time } \\
\text { since } \\
\text { last } \\
\text { meas- } \\
\text { urement } \\
\text { (days) }\end{array}$ & $\begin{array}{l}\text { Pump } \\
\text { running } \\
\text { time } \\
\text { since } \\
\text { last } \\
\text { meas- } \\
\text { urement } \\
\text { (hours) }\end{array}$ & $\begin{array}{l}\text { Average } \\
\text { pumping } \\
\text { rate for } \\
\text { period of } \\
\text { time since } \\
\text { last meas- } \\
\text { urement } \\
\text { (h/d) }\end{array}$ & $\begin{array}{l}\text { Pipeflow } \\
\text { measured } \\
\text { by nonin- } \\
\text { vasive flow- } \\
\text { meter } \\
\text { (gal } / \mathrm{min} \text { ) }\end{array}$ & $\begin{array}{l}\text { Pipeflow } \\
\text { meas- } \\
\text { sured } \\
\text { by inline } \\
\text { flowmeter } \\
\text { (gal/min) }\end{array}$ & $\begin{array}{l}\text { Water } \\
\text { flowing } \\
\text { through in- } \\
\text { line flow- } \\
\text { meter since } \\
\text { last meas- } \\
\text { urement } \\
\text { (gal) }\end{array}$ \\
\hline Hoxie & 30719 & $\begin{array}{r}5-08-90 \\
6-12-90 \\
7-16-90 \\
8-14-90 \\
9-25-90 \\
11-14-90 \\
12-12-90 \\
1-16-91 \\
2-13-91 \\
3-19-91 \\
\text { Average }\end{array}$ & $\begin{array}{r}- \\
35 \\
34 \\
29 \\
42 \\
50 \\
28 \\
35 \\
28 \\
33 \\
\text { NA }\end{array}$ & $\begin{array}{l}- \\
256 \\
388 \\
303 \\
422 \\
465 \\
259 \\
335 \\
272 \\
322 \\
\text { NA }\end{array}$ & $\begin{array}{r}- \\
7.3 \\
11.4 \\
10.4 \\
10.0 \\
9.3 \\
9.3 \\
9.6 \\
9.7 \\
9.8 \\
\text { NA }\end{array}$ & $\begin{array}{r}- \\
572 \\
-\overline{-} \\
504 \\
416 \\
510 \\
- \\
501 \\
496 \\
500 \\
500\end{array}$ & $\begin{array}{l}* * \\
* * \\
* * \\
* * \\
* * \\
* * \\
* * \\
* * \\
* * \\
* * \\
\mathrm{NA}\end{array}$ & $\begin{array}{l}* * \\
* * \\
* * \\
* * \\
* * \\
* * \\
* * \\
* * \\
* * \\
* * \\
\text { NA }\end{array}$ \\
\hline $\begin{array}{l}\text { Mountain } \\
\text { Home } \\
\text { Pump 1 }\end{array}$ & 30812 & $\begin{array}{r}6-13-90 \\
7-18-90 \\
8-14-90 \\
9-26-90 \\
11-15-90 \\
12-13-90 \\
1-17-91 \\
2-14-91 \\
\text { Average }\end{array}$ & $\begin{array}{r}- \\
35 \\
27 \\
43 \\
50 \\
28 \\
35 \\
28 \\
\text { NA }\end{array}$ & $\begin{array}{r}- \\
- \\
383 \\
680 \\
389 \\
293 \\
275 \\
210 \\
\text { NA }\end{array}$ & $\begin{array}{r}- \\
- \\
14.2 \\
15.8 \\
13.8 \\
10.5 \\
7.9 \\
7.5 \\
\text { NA }\end{array}$ & $\begin{array}{l}1,355 \\
1,267 \\
1,297 \\
1,270 \\
1,210 \\
1,233 \\
1,277 \\
1,273 \\
1,242\end{array}$ & $\begin{array}{l}* * \\
* * \\
* * \\
* * \\
* * \\
* * \\
* * \\
* * \\
\text { NA }\end{array}$ & $\begin{array}{l}* * \\
* * \\
* * \\
* * \\
* * \\
* * \\
* * \\
* * \\
\text { NA }\end{array}$ \\
\hline $\begin{array}{c}\text { Mountain } \\
\text { Home } \\
\text { Pump 2 }\end{array}$ & 30812 & $\begin{array}{r}6-13-90 \\
7-18-90 \\
8-14-90 \\
9-26-90 \\
11-15-90 \\
12-13-90 \\
1-17-91 \\
2-14-91 \\
\text { Average }\end{array}$ & $\begin{array}{r}- \\
35 \\
27 \\
43 \\
50 \\
28 \\
35 \\
28 \\
\text { NA }\end{array}$ & $\begin{array}{l}- \\
- \\
626 \\
964 \\
951 \\
550 \\
739 \\
896 \\
\text { NA }\end{array}$ & $\begin{array}{c}- \\
- \\
23.2 \\
22.4 \\
19.0 \\
19.6 \\
21.1 \\
32.0 \\
\text { NA }\end{array}$ & $\begin{array}{l}1,270 \\
1,176 \\
1,267 \\
1,245 \\
1,280 \\
1,210 \\
1,245 \\
1,242 \\
1,242\end{array}$ & $\begin{array}{r}* * \\
* * \\
* * \\
* * \\
* * \\
* * \\
* * \\
* * \\
\text { NA }\end{array}$ & $\begin{array}{l}* * \\
* * \\
* * \\
* * \\
* * \\
* * \\
* * \\
* * \\
\text { NA }\end{array}$ \\
\hline $\begin{array}{c}\text { Mountain } \\
\text { Home } \\
\text { Pump } 3\end{array}$ & 30812 & $\begin{array}{r}7-18-90 \\
8-14-90 \\
9-26-90 \\
11-15-90 \\
12-13-90 \\
1-17-91 \\
2-14-91 \\
\text { Average }\end{array}$ & $\begin{array}{r}- \\
27 \\
43 \\
50 \\
28 \\
35 \\
28 \\
\text { NA }\end{array}$ & $\begin{array}{r}- \\
- \\
449 \\
89 \\
87 \\
78 \\
16 \\
\text { NA }\end{array}$ & $\begin{array}{r}- \\
\overline{-} \\
10.4 \\
1.8 \\
3.1 \\
2.2 \\
{ }^{.6}\end{array}$ & $\begin{array}{l}* * \\
* * \\
* * \\
* * \\
* * \\
* * \\
* * \\
\text { NA }\end{array}$ & $\begin{array}{l}* * \\
* * \\
* * \\
* * \\
* * \\
* \\
* * \\
\text { NA }\end{array}$ & $\begin{array}{l}* * \\
* * \\
* * \\
* * \\
* * \\
* * \\
* * \\
\text { NA }\end{array}$ \\
\hline
\end{tabular}




\begin{tabular}{|c|c|c|c|c|c|c|c|c|}
\hline $\begin{array}{c}\text { Facility } \\
\text { name }\end{array}$ & $\begin{array}{c}\text { Facility } \\
\text { ID } \\
\text { (fig. 1) }\end{array}$ & $\begin{array}{l}\text { Measure- } \\
\text { ment } \\
\text { date }\end{array}$ & $\begin{array}{l}\text { Pump } \\
\text { running } \\
\text { time } \\
\text { since } \\
\text { last } \\
\text { meas- } \\
\text { urement } \\
\text { (days) }\end{array}$ & $\begin{array}{l}\text { Pump } \\
\text { running } \\
\text { time } \\
\text { since } \\
\text { last } \\
\text { meas- } \\
\text { urement } \\
\text { (hours) }\end{array}$ & $\begin{array}{l}\text { Average } \\
\text { pumping } \\
\text { rate for } \\
\text { period of } \\
\text { time since } \\
\text { last meas- } \\
\text { urement } \\
(\mathrm{h} / \mathrm{d})\end{array}$ & $\begin{array}{l}\text { Pipeflow } \\
\text { measured } \\
\text { by nonin- } \\
\text { vasive flow- } \\
\text { meter } \\
\text { (gal } / \mathrm{min} \text { ) }\end{array}$ & $\begin{array}{l}\text { Pipeflow } \\
\text { meas- } \\
\text { sured } \\
\text { by inline } \\
\text { flowmeter } \\
\text { (gal/min) }\end{array}$ & $\begin{array}{l}\text { Water } \\
\text { flowing } \\
\text { through in- } \\
\text { line flow- } \\
\text { meter since } \\
\text { last meas- } \\
\text { urement } \\
\text { (gal) }\end{array}$ \\
\hline $\begin{array}{c}\text { Norphlet } \\
\text { Well } 1\end{array}$ & 30830 & $\begin{array}{r}6-20-90 \\
7-24-90 \\
8-28-90 \\
9-17-90 \\
10-15-90 \\
11-26-90 \\
12-19-90 \\
1-23-91 \\
2-26-91 \\
3-25-91 \\
\text { Average }\end{array}$ & $\begin{array}{r}- \\
34 \\
- \\
55 \\
28 \\
42 \\
23 \\
35 \\
35 \\
27 \\
\text { NA }\end{array}$ & $\begin{array}{r}- \\
26 \\
- \\
144 \\
64 \\
85 \\
61 \\
96 \\
93 \\
- \\
\text { NA }\end{array}$ & $\begin{array}{c}\overline{0} \\
\overline{0} \\
\overline{2} \\
2.6 \\
2.3 \\
2.0 \\
2.6 \\
2.7 \\
2.7 \\
\overline{\text { NA }}\end{array}$ & $\begin{array}{r}270 \\
- \\
- \\
- \\
275 \\
- \\
277 \\
272 \\
275 \\
274 \\
274\end{array}$ & $\begin{array}{r}265 \\
- \\
- \\
- \\
280 \\
- \\
275 \\
270 \\
- \\
\frac{273}{273}\end{array}$ & $\begin{array}{r}* * \\
5,238,030 \\
3,744,000 \\
1,979,870 \\
1,803,390 \\
3,198,690 \\
1,381,760 \\
2,702,830 \\
2,245,470 \\
1,642,350 \\
\text { NA }\end{array}$ \\
\hline $\begin{array}{c}\text { Norphlet } \\
\text { Well } 2\end{array}$ & 30830 & $\begin{array}{r}6-20-90 \\
7-24-90 \\
8-28-90 \\
9-17-90 \\
10-15-90 \\
11-26-90 \\
12-19-90 \\
1-23-91 \\
2-26-91 \\
3-25-91 \\
\text { Average }\end{array}$ & $\begin{array}{r}- \\
34 \\
35 \\
20 \\
28 \\
42 \\
23 \\
35 \\
34 \\
27 \\
\text { NA }\end{array}$ & $\begin{array}{r}- \\
48 \\
127 \\
111 \\
84 \\
180 \\
120 \\
198 \\
221 \\
161 \\
\text { NA }\end{array}$ & $\begin{array}{c}- \\
1.4 \\
3.6 \\
5.5 \\
3.0 \\
4.3 \\
5.2 \\
5.6 \\
6.5 \\
- \\
\text { NA }\end{array}$ & $\begin{array}{r}204 \\
- \\
- \\
- \\
228 \\
- \\
216 \\
- \\
226 \\
\frac{219}{219}\end{array}$ & $\begin{array}{l}* * \\
* * \\
* * \\
* * \\
* * \\
* * \\
* * \\
* * \\
* * \\
* * \\
\text { NA }\end{array}$ & $\begin{array}{l}* * \\
* * \\
* * \\
* * \\
* * \\
* * \\
* * \\
* * \\
* * \\
* * \\
\text { NA }\end{array}$ \\
\hline $\begin{array}{l}\text { Ogden } \\
\text { Well } 1\end{array}$ & 30836 & $\begin{array}{r}6-18-90 \\
7-26-90 \\
8-30-90 \\
9-21-90 \\
10-15-90 \\
11-20-90 \\
12-19-90 \\
1-23-91 \\
2-28-91 \\
3-25-91 \\
\text { Average }\end{array}$ & $\begin{array}{r}- \\
38 \\
35 \\
22 \\
24 \\
36 \\
29 \\
35 \\
36 \\
25 \\
\text { NA }\end{array}$ & $\begin{array}{l}- \\
369 \\
582 \\
342 \\
290 \\
487 \\
291 \\
587 \\
710 \\
157 \\
\text { NA }\end{array}$ & $\begin{array}{c}- \\
9.7 \\
16.6 \\
15.5 \\
12.1 \\
13.5 \\
10.0 \\
16.8 \\
19.7 \\
- \\
\text { NA }\end{array}$ & $\begin{array}{r}- \\
- \\
- \\
126 \\
132 \\
130 \\
132 \\
- \\
- \\
\frac{101}{124}\end{array}$ & $\begin{array}{r}- \\
130 \\
125 \\
130 \\
- \\
128 \\
- \\
- \\
- \\
128 \\
128\end{array}$ & $\begin{array}{r}- \\
2,819,860 \\
1,654,470 \\
1,471,260 \\
2,424,530 \\
1,393,650 \\
2,843,935 \\
2,733,155 \\
1,480,780 \\
- \\
\text { NA }\end{array}$ \\
\hline $\begin{array}{l}\text { Ogden } \\
\text { Well } 2\end{array}$ & 30836 & $\begin{array}{r}6-18-90 \\
7-26-90 \\
8-30-90 \\
9-21-90 \\
10-15-90 \\
11-20-90 \\
12-19-90 \\
1-23-91 \\
1-23-91 \\
2-28-91 \\
3-25-91 \\
\text { Average }\end{array}$ & $\begin{array}{r}- \\
38 \\
35 \\
22 \\
24 \\
36 \\
29 \\
35 \\
35 \\
36 \\
25 \\
\text { NA }\end{array}$ & $\begin{array}{l}- \\
- \\
- \\
- \\
- \\
- \\
- \\
- \\
- \\
- \\
- \\
\text { NA }\end{array}$ & $\begin{array}{l}- \\
- \\
- \\
- \\
- \\
- \\
- \\
- \\
- \\
- \\
- \\
\text { NA }\end{array}$ & $\begin{array}{r}109 \\
- \\
- \\
- \\
126 \\
119 \\
126 \\
128 \\
128 \\
133 \\
\frac{124}{124}\end{array}$ & $\begin{array}{r}120 \\
- \\
120 \\
- \\
128 \\
121 \\
120 \\
120 \\
120 \\
130 \\
\frac{123}{123}\end{array}$ & $\begin{array}{r}- \\
- \\
3,342,000 \\
- \\
- \\
2,400,463 \\
661,288 \\
1,436,874 \\
1,436,874 \\
1,346,375 \\
780,110 \\
\mathrm{NA}\end{array}$ \\
\hline
\end{tabular}


Table 4.--Flow data collected from public water-supply systems in Arkansas where record of pump running time was determined from elther electric energy consumption or vibration time totallzer--Continued

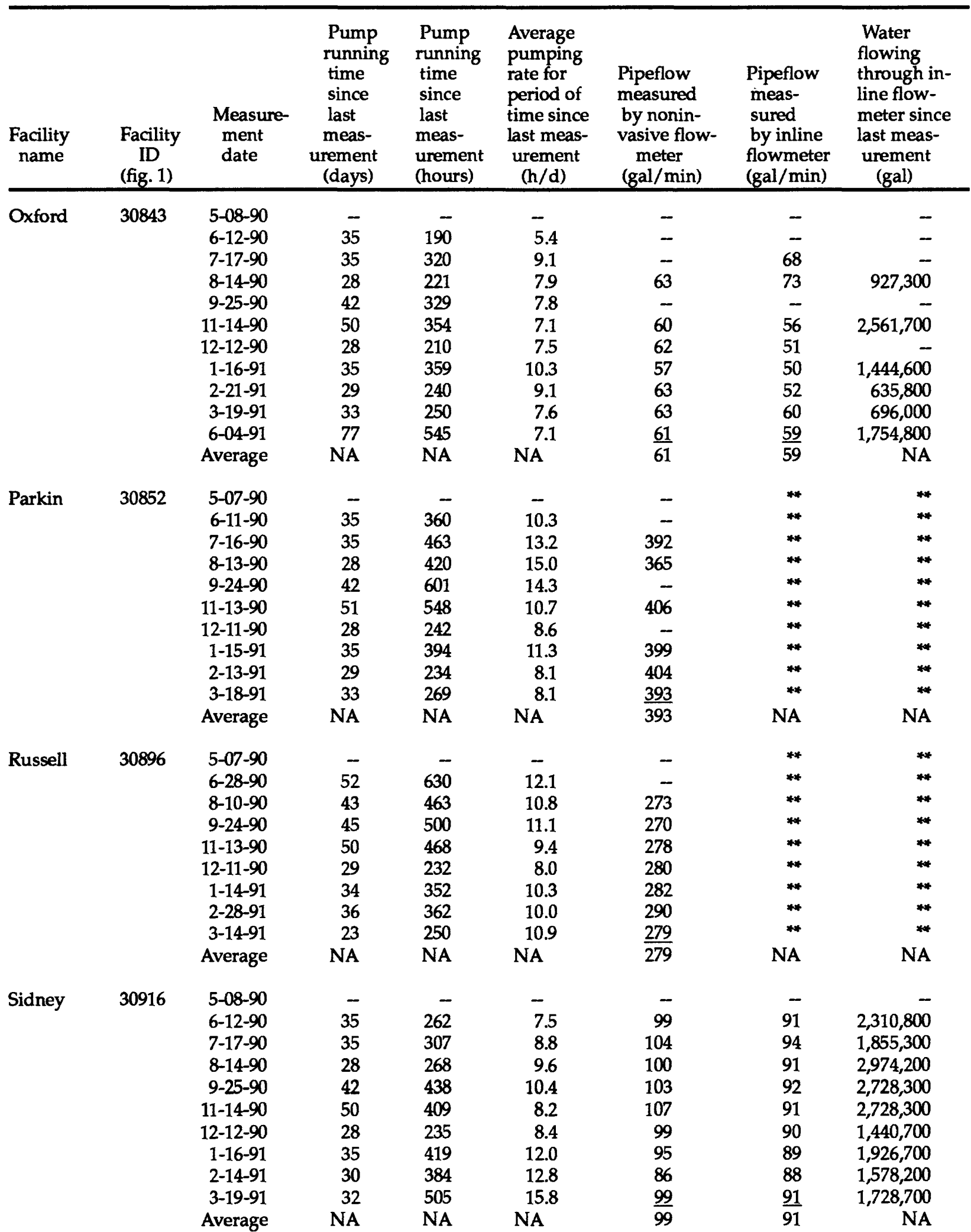


Table 4. --Flow data collected from public water-supply systems in Arkansas where recond of pump running time was determined from either electric energy consumption or vibration time fotalizer-Continued

\begin{tabular}{|c|c|c|c|c|c|c|c|c|}
\hline $\begin{array}{c}\text { Facility } \\
\text { name }\end{array}$ & $\begin{array}{c}\text { Facility } \\
\text { ID } \\
\text { (fig. 1) }\end{array}$ & $\begin{array}{l}\text { Measure- } \\
\text { ment } \\
\text { date }\end{array}$ & $\begin{array}{l}\text { Pump } \\
\text { running } \\
\text { time } \\
\text { since } \\
\text { last } \\
\text { meas- } \\
\text { urement } \\
\text { (days) }\end{array}$ & $\begin{array}{l}\text { Pump } \\
\text { running } \\
\text { time } \\
\text { since } \\
\text { last } \\
\text { meas- } \\
\text { urement } \\
\text { (hours) }\end{array}$ & $\begin{array}{l}\text { Average } \\
\text { pumping } \\
\text { rate for } \\
\text { period of } \\
\text { time since } \\
\text { last meas- } \\
\text { urement } \\
\text { (h/d) }\end{array}$ & $\begin{array}{l}\text { Pipeflow } \\
\text { measured } \\
\text { by nonin- } \\
\text { vasive flow- } \\
\text { meter } \\
\text { (gal/min) }\end{array}$ & $\begin{array}{l}\text { Pipeflow } \\
\text { meas- } \\
\text { sured } \\
\text { by inline } \\
\text { flowmeter } \\
\text { (gal/min) }\end{array}$ & $\begin{array}{l}\text { Water } \\
\text { flowing } \\
\text { through in- } \\
\text { line flow- } \\
\text { meter since } \\
\text { last meas- } \\
\text { urement } \\
\text { (gal) }\end{array}$ \\
\hline $\begin{array}{l}\text { St. Paul } \\
\text { Well } 1\end{array}$ & 30925 & $\begin{array}{r}7-16-90 \\
8-16-90 \\
9-28-90 \\
11-16-90 \\
12-07-90 \\
1-19-91 \\
2-20-91 \\
3-21-91 \\
\text { Average }\end{array}$ & $\begin{array}{r}- \\
31 \\
43 \\
48 \\
22 \\
42 \\
33 \\
29 \\
\text { NA }\end{array}$ & $\begin{array}{l}2 \overline{-} \\
463 \\
593 \\
285 \\
576 \\
582 \\
389 \\
\text { NA }\end{array}$ & $\begin{array}{r}- \\
6.8 \\
10.8 \\
12.1 \\
13.6 \\
13.7 \\
17.6 \\
13.4 \\
\text { NA }\end{array}$ & $\begin{array}{l}15 \\
16 \\
21 \\
20 \\
13 \\
13 \\
15 \\
16 \\
16\end{array}$ & $\begin{array}{l}13 \\
12 \\
14 \\
14 \\
15 \\
13 \\
14 \\
14 \\
14\end{array}$ & $\begin{array}{r}- \\
- \\
324,000 \\
492,900 \\
231,700 \\
479,900 \\
479,100 \\
365,800 \\
\text { NA }\end{array}$ \\
\hline $\begin{array}{l}\text { St. Paul } \\
\text { Well } 2\end{array}$ & & $\begin{array}{r}7-16-90 \\
8-16-90 \\
9-28-90 \\
11-16-90 \\
12-07-90 \\
1-19-91 \\
2-20-91 \\
3-21-91 \\
\text { Average }\end{array}$ & $\begin{array}{r}- \\
31 \\
43 \\
48 \\
22 \\
42 \\
33 \\
29 \\
\text { NA }\end{array}$ & $\begin{array}{r}542 \\
- \\
- \\
- \\
238 \\
603 \\
472 \\
359 \\
\text { NA }\end{array}$ & $\begin{array}{c}17.5 \\
- \\
- \\
- \\
10.8 \\
14.4 \\
14.3 \\
12.4 \\
\text { NA }\end{array}$ & $\begin{array}{l}15 \\
- \\
15 \\
15 \\
17 \\
15 \\
15 \\
\frac{15}{15}\end{array}$ & $\begin{array}{l}13 \\
- \\
- \\
13 \\
13 \\
13 \\
- \\
\frac{13}{13}\end{array}$ & $\begin{array}{l}* \\
* \\
* \\
* \\
* \\
* \\
* \\
* \\
* \\
\text { NA }\end{array}$ \\
\hline $\begin{array}{l}\text { Trumann } \\
\quad \text { City Hall } \\
\text { Well }\end{array}$ & 30950 & $\begin{array}{r}6-11-90 \\
7-17-90 \\
8-13-90 \\
9-24-90 \\
11-13-90 \\
12-11-90 \\
1-15-91 \\
2-13-91 \\
3-18-91 \\
\text { Average }\end{array}$ & $\begin{array}{r}- \\
35 \\
28 \\
42 \\
50 \\
28 \\
35 \\
29 \\
33 \\
\text { NA }\end{array}$ & $\begin{array}{r}- \\
514 \\
397 \\
556 \\
173 \\
659 \\
375 \\
312 \\
278 \\
\text { NA }\end{array}$ & $\begin{array}{r}- \\
14.7 \\
14.2 \\
13.2 \\
3.5 \\
23.5 \\
10.7 \\
10.7 \\
8.4 \\
\text { NA }\end{array}$ & $\begin{array}{r}- \\
- \\
1,061 \\
962 \\
961 \\
1,002 \\
1,011 \\
1,012 \\
1,002 \\
1,002\end{array}$ & $\begin{array}{r}* * \\
* * \\
* * \\
* * \\
* * \\
* * \\
* * \\
* \\
* * \\
\text { NA }\end{array}$ & $\begin{array}{l}* * \\
* \\
* \\
* \\
* * \\
* \\
* \\
* \\
* \\
* \\
\text { NA }\end{array}$ \\
\hline $\begin{array}{l}\text { Trumann } \\
\text { Water Plan } \\
\text { Well }\end{array}$ & 30950 & $\begin{array}{r}5-07-90 \\
6-11-90 \\
7-17-90 \\
8-13-90 \\
9-24-90 \\
11-13-90 \\
12-11-90 \\
1-15-91 \\
2-13-91 \\
3-18-91 \\
\text { Average }\end{array}$ & $\begin{array}{r}- \\
- \\
36 \\
27 \\
42 \\
50 \\
28 \\
35 \\
29 \\
33 \\
\text { NA }\end{array}$ & $\begin{array}{r}- \\
- \\
358 \\
303 \\
416 \\
741 \\
85 \\
295 \\
234 \\
253 \\
\text { NA }\end{array}$ & $\begin{array}{r}- \\
- \\
9.9 \\
11.2 \\
9.9 \\
14.8 \\
3.0 \\
8.4 \\
8.1 \\
7.7 \\
\text { NA }\end{array}$ & $\begin{array}{r}888 \\
850 \\
888 \\
888 \\
888 \\
- \\
- \\
- \\
- \\
880 \\
880\end{array}$ & $\begin{array}{l}* * \\
* * \\
* * \\
* * \\
* * \\
* * \\
* * \\
* * \\
* * \\
* * \\
\text { NA }\end{array}$ & $\begin{array}{l}* \\
* * \\
* * \\
* \\
* \\
* \\
* \\
* \\
* \\
* \\
* \\
\text { NA }\end{array}$ \\
\hline
\end{tabular}


Table 4.--Flow data collected from publlc water-supply systems in Arkansas where record of pump running time was determined from either electric energy consumption or vibration time totalizer--Continued

\begin{tabular}{|c|c|c|c|c|c|c|c|c|}
\hline $\begin{array}{c}\text { Facility } \\
\text { name }\end{array}$ & $\begin{array}{c}\text { Facility } \\
\text { ID } \\
\text { (fig. 1) }\end{array}$ & $\begin{array}{l}\text { Measure- } \\
\text { ment } \\
\text { date }\end{array}$ & $\begin{array}{l}\text { Pump } \\
\text { running } \\
\text { time } \\
\text { since } \\
\text { last } \\
\text { meas- } \\
\text { urement } \\
\text { (days) } \\
\end{array}$ & $\begin{array}{l}\text { Pump } \\
\text { running } \\
\text { time } \\
\text { since } \\
\text { last } \\
\text { meas- } \\
\text { urement } \\
\text { (hours) }\end{array}$ & $\begin{array}{l}\text { Average } \\
\text { pumping } \\
\text { rate for } \\
\text { period of } \\
\text { time since } \\
\text { last meas- } \\
\text { urement } \\
(\mathrm{h} / \mathrm{d})\end{array}$ & $\begin{array}{l}\text { Pipeflow } \\
\text { measured } \\
\text { by nonin- } \\
\text { vasive flow- } \\
\text { meter } \\
\text { (gal/min) }\end{array}$ & $\begin{array}{l}\text { Pipeflow } \\
\text { meas- } \\
\text { sured } \\
\text { by inline } \\
\text { flowmeter } \\
\text { (gal/min) }\end{array}$ & $\begin{array}{l}\text { Water } \\
\text { flowing } \\
\text { through in- } \\
\text { line flow- } \\
\text { meter since } \\
\text { last meas- } \\
\text { urement } \\
\text { (gal) }\end{array}$ \\
\hline $\begin{array}{l}\text { Ward } \\
\text { Well } 2\end{array}$ & 30969 & $\begin{array}{r}5-07-90 \\
6-28-90 \\
8-10-90 \\
9-24-90 \\
11-13-90 \\
12-12-90 \\
2-19-91 \\
3-17-91 \\
\text { Average }\end{array}$ & $\begin{array}{r}- \\
52 \\
43 \\
45 \\
50 \\
29 \\
69 \\
26 \\
\text { NA }\end{array}$ & $\begin{array}{r}- \\
846 \\
324 \\
425 \\
683 \\
158 \\
1,535 \\
309 \\
\text { NA }\end{array}$ & $\begin{array}{r}- \\
16.3 \\
7.5 \\
9.4 \\
13.7 \\
5.4 \\
22.2 \\
11.9 \\
\text { NA }\end{array}$ & $\begin{array}{l}213 \\
225 \\
312 \\
308 \\
327 \\
338 \\
355 \\
\frac{297}{297}\end{array}$ & $\begin{array}{l}* * \\
* * \\
* * \\
* * \\
* * \\
* * \\
* * \\
* * \\
\text { NA }\end{array}$ & $\begin{array}{l}* * \\
* * \\
* * \\
* * \\
* * \\
* * \\
* * \\
* * \\
\text { NA }\end{array}$ \\
\hline $\begin{array}{l}\text { Ward } \\
\text { Well } 4\end{array}$ & 30969 & $\begin{array}{r}5-07-90 \\
6-28-90 \\
8-10-90 \\
9-24-90 \\
11-13-90 \\
12-12-90 \\
2-19-91 \\
3-17-91 \\
\text { Average }\end{array}$ & $\begin{array}{r}- \\
52 \\
43 \\
45 \\
50 \\
29 \\
69 \\
26 \\
\text { NA }\end{array}$ & $\begin{array}{l}* * \\
* * \\
* * \\
* * \\
* * \\
* * \\
* * \\
* * \\
\text { NA }\end{array}$ & $\begin{array}{l}* * \\
* * \\
* * \\
* * \\
* * \\
* * \\
* \\
* * \\
\text { NA }\end{array}$ & $\begin{array}{l}482 \\
479 \\
488 \\
492 \\
480 \\
478 \\
485 \\
\frac{483}{483}\end{array}$ & $\begin{array}{l}* * \\
* * \\
* * \\
* * \\
* * \\
* * \\
* \\
* * \\
\text { NA }\end{array}$ & $\begin{array}{l}* * \\
* * \\
* * \\
* * \\
* * \\
* * \\
* * \\
* * \\
\text { NA }\end{array}$ \\
\hline $\begin{array}{l}\text { Yorktown } \\
\text { Well } 1\end{array}$ & 31004 & $\begin{array}{r}11-30-90 \\
12-17-90 \\
1-08-91 \\
1-28-91 \\
2-26-91 \\
3-28-91 \\
\text { Average }\end{array}$ & $\begin{array}{r}- \\
18 \\
22 \\
20 \\
29 \\
30 \\
\text { NA }\end{array}$ & $\begin{array}{r}- \\
44 \\
49 \\
168 \\
331 \\
518 \\
\text { NA }\end{array}$ & $\begin{array}{r}\overline{2} \\
2.4 \\
2.2 \\
7.6 \\
11.4 \\
17.3 \\
\text { NA }\end{array}$ & $\begin{array}{r}- \\
- \\
336 \\
311 \\
311 \\
\frac{319}{319}\end{array}$ & $\begin{array}{r}- \\
\overline{3} \\
340 \\
\overline{340} \\
\frac{340}{340}\end{array}$ & $\begin{array}{r}- \\
1,810,100 \\
- \\
5,366,200 \\
3,289,000 \\
3,532,700 \\
\text { NA }\end{array}$ \\
\hline $\begin{array}{l}\text { Yorktown } \\
\text { Well } 2\end{array}$ & 31004 & $\begin{array}{r}5-31-90 \\
6-01-90 \\
7-30-90 \\
8-22-90 \\
9-18-90 \\
10-11-90 \\
11-30-90 \\
12-17-90 \\
1-28-91 \\
2-26-91 \\
3-28-91 \\
\text { Average }\end{array}$ & $\begin{array}{r}- \\
2 \\
60 \\
23 \\
27 \\
23 \\
41 \\
26 \\
42 \\
29 \\
32 \\
\text { NA }\end{array}$ & $\begin{array}{r}- \\
20 \\
303 \\
554 \\
602 \\
457 \\
603 \\
285 \\
276 \\
214 \\
201 \\
\text { NA }\end{array}$ & $\begin{array}{r}- \\
10.0 \\
5.0 \\
24.0 \\
22.3 \\
19.9 \\
14.7 \\
11.0 \\
6.6 \\
7.4 \\
6.3 \\
\text { NA }\end{array}$ & $\begin{array}{r}- \\
366 \\
360 \\
\overline{3} \\
330 \\
357 \\
- \\
- \\
- \\
\overline{-}\end{array}$ & $\begin{array}{r}- \\
- \\
353 \\
310 \\
330 \\
360 \\
350 \\
- \\
- \\
- \\
341\end{array}$ & $\begin{array}{r}- \\
- \\
- \\
8,840,000 \\
2,731,000 \\
10,091,000 \\
12,421,200 \\
3,760,100 \\
7,122,450 \\
4,118,250 \\
4,174,000 \\
\text { NA }\end{array}$ \\
\hline
\end{tabular}


Table 4.--Flow data collected from public water-supply systems in Arkansas where record of pump running time was determined from elther electric energy consumption or vibration time totallzer--Continued

\begin{tabular}{|c|c|c|c|c|c|c|c|c|}
\hline $\begin{array}{l}\text { Facility } \\
\text { name }\end{array}$ & $\begin{array}{l}\text { Facility } \\
\text { ID } \\
\text { (fig. 1) }\end{array}$ & $\begin{array}{l}\text { Measure- } \\
\text { ment } \\
\text { date }\end{array}$ & $\begin{array}{l}\text { Pump } \\
\text { running } \\
\text { time } \\
\text { since } \\
\text { last } \\
\text { meas- } \\
\text { urement } \\
\text { (days) }\end{array}$ & $\begin{array}{l}\text { Pump } \\
\text { running } \\
\text { time } \\
\text { since } \\
\text { last } \\
\text { meas- } \\
\text { urement } \\
\text { (hours) }\end{array}$ & $\begin{array}{l}\text { Average } \\
\text { pumping } \\
\text { rate for } \\
\text { period of } \\
\text { time since } \\
\text { last meas- } \\
\text { urement } \\
\text { (h/d) }\end{array}$ & $\begin{array}{l}\text { Pipeflow } \\
\text { measured } \\
\text { by nonin- } \\
\text { vasive flow- } \\
\text { meter } \\
(\mathrm{gal} / \mathrm{min})\end{array}$ & $\begin{array}{l}\text { Pipeflow } \\
\text { meas- } \\
\text { sured } \\
\text { by inline } \\
\text { flowmeter } \\
\text { (gal/min) }\end{array}$ & $\begin{array}{l}\text { Water } \\
\text { flowing } \\
\text { through in- } \\
\text { line flow- } \\
\text { meter since } \\
\text { last meas- } \\
\text { urement } \\
\text { (gal) }\end{array}$ \\
\hline $\begin{array}{l}\text { Yorktown } \\
\text { Well } 3\end{array}$ & 31004 & $\begin{array}{r}5-31-90 \\
6-01-90 \\
7-30-90 \\
8-22-90 \\
9-18-90 \\
10-11-90 \\
11-30-90 \\
12-17-90 \\
1-28-91 \\
2-26-91 \\
3-28-91 \\
\text { Average }\end{array}$ & $\begin{array}{r}- \\
2 \\
60 \\
23 \\
27 \\
23 \\
41 \\
26 \\
42 \\
29 \\
32 \\
\text { NA }\end{array}$ & $\begin{array}{l}5.5 \\
673 \\
216 \\
121 \\
126 \\
318 \\
187 \\
316 \\
180 \\
185 \\
\text { NA }\end{array}$ & $\begin{array}{r}- \\
2.8 \\
11.2 \\
9.4 \\
4.5 \\
5.5 \\
7.8 \\
7.2 \\
7.5 \\
6.2 \\
5.8 \\
\text { NA }\end{array}$ & $\begin{array}{r}- \\
- \\
287 \\
396 \\
- \\
295 \\
308 \\
308 \\
306 \\
305 \\
\underline{315} \\
315\end{array}$ & $\begin{array}{r}315 \\
- \\
310 \\
405 \\
- \\
304 \\
307 \\
305 \\
304 \\
303 \\
\frac{319}{319}\end{array}$ & $\begin{array}{r}- \\
- \\
- \\
3,993,800 \\
4,209,700 \\
2,876,970 \\
6,109,309 \\
3,301,259 \\
5,502,412 \\
3,549,990 \\
3,179,890 \\
\text { NA }\end{array}$ \\
\hline $\begin{array}{l}\text { Yorktown } \\
\text { Well } 5\end{array}$ & 31004 & $\begin{array}{r}5-31-90 \\
6-01-90 \\
7-30-90 \\
8-22-90 \\
9-18-90 \\
10-11-90 \\
11-30-90 \\
12-17-90 \\
1-28-91 \\
2-26-91 \\
3-28-91 \\
\text { Average }\end{array}$ & $\begin{array}{r}- \\
2 \\
60 \\
23 \\
27 \\
23 \\
41 \\
26 \\
42 \\
29 \\
32 \\
\text { NA }\end{array}$ & $\begin{array}{r}\overline{5} \\
419 \\
208 \\
183 \\
96 \\
213 \\
140 \\
258 \\
175 \\
129 \\
\mathrm{NA}\end{array}$ & $\begin{array}{r}- \\
2.5 \\
7.0 \\
9.0 \\
6.8 \\
4.2 \\
5.2 \\
5.4 \\
6.1 \\
6.0 \\
4.0 \\
\text { NA }\end{array}$ & $\begin{array}{r}-\overline{3} \\
- \\
314 \\
320 \\
330 \\
327 \\
317 \\
306 \\
311 \\
319 \\
319\end{array}$ & $\begin{array}{r}315 \\
- \\
310 \\
405 \\
- \\
304 \\
307 \\
305 \\
304 \\
303 \\
319 \\
319\end{array}$ & $\begin{array}{r}- \\
103,000 \\
8,137,265 \\
3,273,505 \\
3,279,230 \\
2,575,000 \\
3,272,000 \\
2,463,300 \\
4,342,705 \\
3,083,000 \\
2,389,200 \\
\text { NA }\end{array}$ \\
\hline
\end{tabular}


Table 5. --Pipeffow measurements made at public-supply facilities in Arkansas by noninvasive and Inilne flowmeter and natural log-percent difference

(ID. identification number; gal/min, gallons per minute; -, no measurement)

\begin{tabular}{|c|c|c|c|c|c|}
\hline $\begin{array}{l}\text { Facility } \\
\text { name }\end{array}$ & $\begin{array}{c}\text { Facility } \\
\text { ID } \\
\text { (fig. 1) }\end{array}$ & $\begin{array}{c}\text { Measure- } \\
\text { ment } \\
\text { date }\end{array}$ & $\begin{array}{c}\text { Pipeflow measured } \\
\text { by noninvasive } \\
\text { flowmeter } \\
\text { (a) } \\
\text { (gal } / \mathrm{min})\end{array}$ & $\begin{array}{c}\text { Pipeflow } \\
\text { measured by } \\
\text { inline flowmeter } \\
\text { (b) } \\
(\mathrm{gal} / \mathrm{min})\end{array}$ & $\begin{array}{c}\text { Natural } \\
\text { log-percent } \\
\text { difference } \\
{[\ln (a / b)] \times 100}\end{array}$ \\
\hline \multirow[t]{8}{*}{ Bergman } & 30547 & $7-18-90$ & 97 & 95 & 2.1 \\
\hline & & $8-15-90$ & 86 & 88 & -2.3 \\
\hline & & $9-27-90$ & 98 & 96 & 2.1 \\
\hline & & $11-15-90$ & 96 & 88 & 8.7 \\
\hline & & $12-06-90$ & 85 & 80 & 6.1 \\
\hline & & $2-21-91$ & 92 & 88 & 4.4 \\
\hline & & $3-20-91$ & $\underline{96}$ & $\underline{90}$ & 6.4 \\
\hline & & Average & $\overline{93}$ & $\overline{89}$ & $\overline{4.4}$ \\
\hline \multirow[t]{8}{*}{ Bigelow } & 30551 & $6-19-90$ & 156 & 160 & -2.5 \\
\hline & & $8-24-90$ & 186 & 187 & -.5 \\
\hline & & $9-13-90$ & 185 & 200 & -7.8 \\
\hline & & $10-12-90$ & 187 & 215 & -14.0 \\
\hline & & $11-28-90$ & 203 & 205 & -1.0 \\
\hline & & $12-18-90$ & 210 & 200 & 4.9 \\
\hline & & $1-22-91$ & $\underline{210}$ & - & - \\
\hline & & Average & $\overline{191}$ & $\overline{194}$ & -1.6 \\
\hline \multirow[t]{9}{*}{ Big Flat } & 30550 & $7-17-90$ & 181 & 172 & 5.1 \\
\hline & & $8-15-90$ & 185 & 180 & 2.7 \\
\hline & & $9-25-90$ & 190 & 182 & 4.3 \\
\hline & & $11-14-90$ & 187 & 177 & 5.5 \\
\hline & & $12-12-90$ & 192 & 179 & 7.0 \\
\hline & & $1-16-91$ & 195 & 183 & 6.4 \\
\hline & & $2-21-91$ & 164 & 160 & 2.5 \\
\hline & & $3-19-91$ & $\underline{173}$ & $\underline{170}$ & 1.7 \\
\hline & & Average & $\overline{183}$ & $\overline{175}$ & $\overline{4.5}$ \\
\hline \multirow[t]{8}{*}{ Black Rock } & 30556 & $9-25-90$ & 231 & 246 & -6.3 \\
\hline & & $11-14-90$ & 227 & 246 & -8.0 \\
\hline & & $12-12-90$ & 222 & 246 & -10.3 \\
\hline & & $1-16-91$ & 220 & 246 & -11.2 \\
\hline & & $2-13-91$ & 222 & - & - \\
\hline & & $3-19-91$ & 222 & 246 & -10.3 \\
\hline & & $6-03-91$ & 238 & $\underline{246}$ & $\underline{-3.3}$ \\
\hline & & Average & $\overline{226}$ & $\overline{246}$ & $\overline{-8.5}$ \\
\hline \multirow[t]{10}{*}{ Carthage } & 30582 & $5-15-90$ & - & 100 & - \\
\hline & & $7-26-90$ & 112 & 120 & -6.9 \\
\hline & & $8-21-90$ & 140 & 150 & -6.9 \\
\hline & & $10-16-90$ & 124 & 120 & 3.3 \\
\hline & & $11-27-90$ & 119 & 120 & -.8 \\
\hline & & $12-17-90$ & 145 & 150 & -3.4 \\
\hline & & $1-29-91$ & 126 & 125 & .8 \\
\hline & & $2-27-91$ & 122 & 130 & -6.4 \\
\hline & & $3-29-91$ & 122 & $\underline{125}$ & -2.4 \\
\hline & & Average & $\overline{126}$ & $\overline{127}$ & $\overline{-.8}$ \\
\hline
\end{tabular}


Table 5.--Pipeffow measurements made at publlc-supply facilities in Arkansas by noninvasive and inline flowmeter and natural log-percent difference--Continued

\begin{tabular}{|c|c|c|c|c|c|}
\hline $\begin{array}{l}\text { Facility } \\
\text { name }\end{array}$ & $\begin{array}{l}\text { Facility } \\
\text { ID } \\
\text { (fig. 1) }\end{array}$ & $\begin{array}{c}\text { Measure- } \\
\text { ment } \\
\text { date }\end{array}$ & $\begin{array}{c}\text { Pipeflow measured } \\
\text { by noninvasive } \\
\text { flowmeter } \\
(\mathrm{a}) \\
\text { (gal } / \mathrm{min})\end{array}$ & $\begin{array}{c}\text { Pipeflow } \\
\text { measured by } \\
\text { inline flowmeter } \\
\text { (b) } \\
\text { (gal } / \mathrm{min})\end{array}$ & $\begin{array}{l}\begin{array}{c}\text { Natural } \\
\text { log-percent } \\
\text { difference }\end{array} \\
{[\ln (\mathrm{a} / \mathrm{b})]}\end{array}$ \\
\hline Cass & 30584 & $\begin{array}{r}7-16-90 \\
8-16-90 \\
9-28-90 \\
11-16-90 \\
12-07-90 \\
1-18-91 \\
2-20-91 \\
3-21-91 \\
\text { Average }\end{array}$ & $\begin{array}{l}42 \\
41 \\
42 \\
51 \\
51 \\
54 \\
54 \\
\underline{54} \\
4\end{array}$ & $\begin{array}{l}- \\
- \\
- \\
- \\
- \\
55 \\
57 \\
\overline{56}\end{array}$ & $\begin{array}{l}- \\
- \\
- \\
- \\
- \\
-1.8 \\
-5.4 \\
\overline{-13.3}\end{array}$ \\
\hline Collins & 30596 & $\begin{array}{r}8-28-90 \\
10-18-90 \\
11-19-90 \\
12-20-90 \\
1-24-91 \\
3-26-91 \\
\text { Average }\end{array}$ & $\begin{array}{r}- \\
121 \\
150 \\
155 \\
154 \\
162 \\
148\end{array}$ & $\begin{array}{l}150 \\
129 \\
150 \\
157 \\
157 \\
\frac{165}{151}\end{array}$ & $\begin{array}{l}- \\
-6.4 \\
0.0 \\
-1.3 \\
-1.9 \\
-1.8 \\
-2.0\end{array}$ \\
\hline Dierks & 30631 & $\begin{array}{r}5-14-90 \\
6-18-90 \\
7-26-90 \\
9-21-90 \\
10-15-90 \\
11-26-90 \\
12-19-90 \\
1-23-91 \\
\text { Average }\end{array}$ & $\begin{array}{r}- \\
- \\
926 \\
715 \\
734 \\
678 \\
599 \\
674 \\
721\end{array}$ & $\begin{array}{l}550 \\
850 \\
940 \\
720 \\
730 \\
675 \\
610 \\
670 \\
718\end{array}$ & $\begin{array}{r}- \\
- \\
-1.5 \\
-.7 \\
.5 \\
.4 \\
-1.8 \\
.6 \\
.4\end{array}$ \\
\hline Franklin & 30666 & $\begin{array}{r}5-08-90 \\
11-14-90 \\
12-12-90 \\
1-16-91 \\
2-14-91 \\
3-19-91 \\
6-04-91 \\
\text { Average }\end{array}$ & $\begin{array}{l}- \\
75 \\
72 \\
81 \\
84 \\
85 \\
80 \\
80\end{array}$ & $\begin{array}{l}75 \\
75 \\
73 \\
83 \\
81 \\
80 \\
83 \\
79\end{array}$ & $\begin{array}{r}- \\
0.0 \\
-1.4 \\
-2.4 \\
3.6 \\
6.1 \\
-3.7 \\
1.3\end{array}$ \\
\hline Gilmore & 30676 & $\begin{array}{r}6-11-90 \\
7-16-90 \\
8-13-90 \\
11-13-90 \\
2-13-91 \\
3-18-91 \\
\text { Average }\end{array}$ & $\begin{array}{l}289 \\
285 \\
288 \\
290 \\
291 \\
\frac{295}{290}\end{array}$ & $\begin{array}{l}300 \\
295 \\
300 \\
300 \\
300 \\
300 \\
299\end{array}$ & $\begin{array}{r}-3.7 \\
-3.4 \\
-4.1 \\
-3.4 \\
-3.0 \\
-1.7 \\
-3.1\end{array}$ \\
\hline
\end{tabular}


Table 5.--Pipeffow measurements made at public-supply facilities in Arkansas by noninvasive and inline flowmeter and natural log-percent difference-Continued

\begin{tabular}{|c|c|c|c|c|c|}
\hline $\begin{array}{l}\text { Facility } \\
\text { name }\end{array}$ & $\begin{array}{l}\text { Facility } \\
\text { ID } \\
\text { (fig. 1) }\end{array}$ & $\begin{array}{l}\text { Measure- } \\
\text { ment } \\
\text { date }\end{array}$ & $\begin{array}{c}\text { Pipeflow measured } \\
\text { by noninvasive } \\
\text { flowmeter } \\
\text { (a) } \\
\text { (gal/min) }\end{array}$ & $\begin{array}{c}\text { Pipeflow } \\
\text { measured by } \\
\text { inline flowmeter } \\
\text { (b) } \\
\text { (gal/min) }\end{array}$ & $\begin{array}{l}\begin{array}{c}\text { Natural } \\
\log -\text { percent } \\
\text { difference }\end{array} \\
{[\ln (a / b)]}\end{array}$ \\
\hline Green Forest & 30686 & $\begin{array}{r}9-26-90 \\
11-15-90 \\
12-06-90 \\
1-17-91 \\
2-20-91 \\
3-20-91 \\
\text { Average }\end{array}$ & $\begin{array}{l}833 \\
848 \\
832 \\
851 \\
848 \\
857 \\
845\end{array}$ & $\begin{array}{l}850 \\
850 \\
850 \\
850 \\
850 \\
850 \\
850\end{array}$ & $\begin{array}{r}-2.0 \\
-.2 \\
-2.1 \\
.1 \\
-.2 \\
.8 \\
-.6\end{array}$ \\
\hline Guy & 30693 & $\begin{array}{r}7-27-90 \\
8-24-90 \\
9-13-90 \\
11-29-90 \\
12-12-90 \\
1-14-91 \\
2-15-91 \\
3-14-91 \\
\text { Average }\end{array}$ & $\begin{array}{r}74 \\
93 \\
104 \\
36 \\
74 \\
72 \\
72 \\
84 \\
100 \\
80\end{array}$ & $\begin{array}{r}72 \\
97 \\
103 \\
33 \\
88 \\
99 \\
92 \\
99 \\
85\end{array}$ & $\begin{array}{r}2.7 \\
-4.2 \\
1.0 \\
8.7 \\
-17.0 \\
-31.8 \\
-9.1 \\
1.0 \\
-6.1\end{array}$ \\
\hline Harrell & 30699 & $\begin{array}{r}9-17-90 \\
10-15-90 \\
11-19-90 \\
12-20-90 \\
1-24-91 \\
3-27-91 \\
\text { Average }\end{array}$ & $\begin{array}{l}142 \\
142 \\
149 \\
147 \\
147 \\
150 \\
146\end{array}$ & $\begin{array}{l}150 \\
145 \\
152 \\
150 \\
150 \\
\frac{150}{150}\end{array}$ & $\begin{array}{r}-5.5 \\
-2.1 \\
-2.0 \\
-2.0 \\
-2.0 \\
0.0 \\
-2.7\end{array}$ \\
\hline Haskell & 30702 & $\begin{array}{r}5-04-90 \\
6-19-90 \\
7-31-90 \\
8-21-90 \\
9-14-90 \\
10-12-90 \\
11-27-90 \\
12-18-90 \\
1-29-91 \\
\text { Average }\end{array}$ & $\begin{array}{l}151 \\
161 \\
107 \\
156 \\
115 \\
119 \\
122 \\
119 \\
\underline{177} \\
136\end{array}$ & $\begin{array}{l}132 \\
140 \\
130 \\
140 \\
127 \\
129 \\
127 \\
125 \\
174 \\
136\end{array}$ & $\begin{array}{r}13.4 \\
14.0 \\
-19.5 \\
10.8 \\
-9.9 \\
-8.1 \\
-4.0 \\
-4.9 \\
1.7 \\
0.0\end{array}$ \\
\hline Holly Grove & 30713 & $\begin{array}{r}7-23-90 \\
9-17-90 \\
10-17-90 \\
11-20-90 \\
12-21-90 \\
1-25-91 \\
\text { Average }\end{array}$ & $\begin{array}{l}468 \\
453 \\
526 \\
415 \\
493 \\
507 \\
477\end{array}$ & $\begin{array}{l}475 \\
450 \\
500 \\
400 \\
500 \\
500 \\
471\end{array}$ & $\begin{array}{r}-1.5 \\
.7 \\
5.1 \\
3.7 \\
-1.4 \\
1.4 \\
1.3\end{array}$ \\
\hline
\end{tabular}


Table 5.--Pipeffow measurements made at public-supply facilities in Arkansas by noninvasive and iniline flowmeter amd natural log-porcent difference-Continued

\begin{tabular}{|c|c|c|c|c|c|}
\hline $\begin{array}{l}\text { Facility } \\
\text { name }\end{array}$ & $\begin{array}{l}\text { Facility } \\
\text { ID } \\
\text { (fig. 1) }\end{array}$ & $\begin{array}{l}\text { Measure- } \\
\text { ment } \\
\text { date }\end{array}$ & $\begin{array}{l}\text { Pipeflow measured } \\
\text { by noninvasive } \\
\text { flowmeter } \\
\text { (a) } \\
\text { (gal } / \mathrm{min})\end{array}$ & $\begin{array}{c}\text { Pipeflow } \\
\text { measured by } \\
\text { inline flowmeter } \\
\text { (b) } \\
\text { (gal/min) }\end{array}$ & $\begin{array}{r}\begin{array}{c}\text { Natural } \\
\log \text {-percent } \\
\text { difference }\end{array} \\
{[\ln (a / b)]}\end{array}$ \\
\hline Huntsville & 30723 & $\begin{array}{r}6-14-90 \\
7-19-90 \\
8-15-90 \\
9-27-90 \\
11-15-90 \\
12-06-90 \\
1-17-91 \\
2-20-91 \\
3-20-91 \\
\text { Average }\end{array}$ & $\begin{array}{r}916 \\
945 \\
920 \\
1,073 \\
944 \\
968 \\
998 \\
989 \\
-\overline{-} \\
\overline{969}\end{array}$ & $\begin{array}{l}930 \\
910 \\
900 \\
925 \\
920 \\
940 \\
950 \\
950 \\
\underline{960} \\
932\end{array}$ & $\begin{array}{r}-1.5 \\
3.8 \\
2.2 \\
14.8 \\
2.6 \\
2.9 \\
4.9 \\
4.0 \\
-- \\
3.9\end{array}$ \\
\hline $\begin{array}{l}\text { Norphlet } \\
\text { Well } 1\end{array}$ & 30830 & $\begin{array}{r}6-20-90 \\
10-15-90 \\
12-19-90 \\
1-23-91 \\
2-26-91 \\
\text { Average }\end{array}$ & $\begin{array}{l}270 \\
275 \\
277 \\
272 \\
\frac{275}{274}\end{array}$ & $\begin{array}{r}265 \\
280 \\
275 \\
270 \\
-- \\
273\end{array}$ & $\begin{array}{r}1.9 \\
-1.8 \\
.7 \\
.7 \\
-. \\
.4\end{array}$ \\
\hline $\begin{array}{l}\text { Ogden } \\
\text { Well } 1\end{array}$ & 30836 & $\begin{array}{r}7-26-90 \\
8-30-90 \\
9-21-90 \\
10-15-90 \\
11-20-90 \\
12-19-90 \\
\text { Average }\end{array}$ & $\begin{array}{r}- \\
-- \\
126 \\
132 \\
130 \\
\frac{132}{130}\end{array}$ & $\begin{array}{r}130 \\
125 \\
130 \\
- \\
128 \\
\overline{128}\end{array}$ & $\begin{array}{l}- \\
\overline{-} \\
-3.1 \\
\overline{1.5} \\
\overline{-} \\
\overline{1.5}\end{array}$ \\
\hline $\begin{array}{l}\text { Ogden } \\
\text { Well } 2\end{array}$ & 30836 & $\begin{array}{r}6-18-90 \\
8-30-90 \\
11-20-90 \\
12-19-90 \\
1-23-91 \\
2-28-91 \\
3-25-91 \\
\text { Average }\end{array}$ & $\begin{array}{r}109 \\
- \\
126 \\
119 \\
126 \\
128 \\
\underline{133} \\
124\end{array}$ & $\begin{array}{l}120 \\
120 \\
128 \\
121 \\
120 \\
120 \\
\frac{130}{123} \\
\end{array}$ & $\begin{array}{l}-9.6 \\
- \\
-1.6 \\
-1.7 \\
4.9 \\
6.4 \\
\underline{2.3} \\
.8\end{array}$ \\
\hline Oxford & 30843 & $\begin{array}{r}7-17-90 \\
8-14-90 \\
9-25-90 \\
11-14-90 \\
12-12-90 \\
1-16-91 \\
2-21-91 \\
3-19-91 \\
6-04-91 \\
\text { Average }\end{array}$ & $\begin{array}{r}- \\
63 \\
- \\
60 \\
- \\
62 \\
57 \\
63 \\
63 \\
61\end{array}$ & $\begin{array}{r}68 \\
73 \\
- \\
56 \\
- \\
51 \\
50 \\
52 \\
60 \\
59\end{array}$ & $\begin{array}{c}- \\
-14.7 \\
-- \\
6.9 \\
-- \\
19.5 \\
13.1 \\
19.2 \\
4.9 \\
3.3\end{array}$ \\
\hline
\end{tabular}


Table 5.--Pipeffow measurements made at public-supply facilities in Arkansas by noninvasive and inline flowmeter and natural log-percent difference-Continued

\begin{tabular}{|c|c|c|c|c|c|}
\hline $\begin{array}{l}\text { Facility } \\
\text { name }\end{array}$ & $\begin{array}{l}\text { Facility } \\
\text { ID } \\
\text { (fig. 1) }\end{array}$ & $\begin{array}{l}\text { Measure- } \\
\text { ment } \\
\text { date }\end{array}$ & $\begin{array}{l}\text { Pipeflow measured } \\
\text { by noninvasive } \\
\text { flowmeter } \\
\text { (a) } \\
(\mathrm{gal} / \mathrm{min})\end{array}$ & $\begin{array}{c}\text { Pipeflow } \\
\text { measured by } \\
\text { inline flowmeter } \\
\text { (b) } \\
(\mathrm{gal} / \mathrm{min})\end{array}$ & $\begin{array}{c}\begin{array}{c}\text { Natural } \\
\text { log-percent } \\
\text { difference }\end{array} \\
{[\ln (\mathrm{a} / \mathrm{b})]}\end{array}$ \\
\hline Perryville & 30859 & $\begin{array}{r}6-01-90 \\
6-19-90 \\
7-31-90 \\
8-24-90 \\
9-14-90 \\
10-12-90 \\
11-28-90 \\
12-17-90 \\
1-22-91 \\
\text { Average }\end{array}$ & $\begin{array}{l}372 \\
707 \\
455 \\
535 \\
597 \\
435 \\
487 \\
567 \\
\underline{471} \\
481\end{array}$ & $\begin{array}{r}- \\
- \\
525 \\
555 \\
400 \\
475 \\
550 \\
455 \\
493\end{array}$ & $\begin{array}{l}- \\
- \\
\overline{1} \\
1.9 \\
7.3 \\
8.4 \\
2.5 \\
3.0 \\
\underline{3.5} \\
-2.5\end{array}$ \\
\hline Prairie Grove & 30871 & $\begin{array}{r}6-14-90 \\
7-10-90 \\
8-16-90 \\
9-27-90 \\
11-15-90 \\
12-06-90 \\
1-17-91 \\
\text { Average }\end{array}$ & $\begin{array}{l}396 \\
453 \\
455 \\
476 \\
472 \\
485 \\
\underline{472} \\
458\end{array}$ & $\begin{array}{r}- \\
458 \\
458 \\
440 \\
440 \\
440 \\
480 \\
453\end{array}$ & $\begin{array}{r}-1 \\
-1.1 \\
-.7 \\
7.9 \\
7.0 \\
9.7 \\
-1.7 \\
1.1\end{array}$ \\
\hline Roe & 30894 & $\begin{array}{r}6-21-90 \\
9-17-90 \\
10-17-90 \\
11-20-90 \\
12-21-90 \\
1-25-91 \\
3-27-91 \\
\text { Average }\end{array}$ & $\begin{array}{l}192 \\
198 \\
155 \\
181 \\
186 \\
182 \\
\underline{186} \\
183\end{array}$ & $\begin{array}{l}180 \\
180 \\
150 \\
180 \\
180 \\
180 \\
180 \\
176\end{array}$ & $\begin{array}{r}6.4 \\
9.5 \\
3.3 \\
.6 \\
3.3 \\
1.1 \\
3.3 \\
3.9\end{array}$ \\
\hline Sidney & 30916 & $\begin{array}{r}6-12-90 \\
8-14-90 \\
9-25-90 \\
11-14-90 \\
12-12-90 \\
1-16-91 \\
2-14-91 \\
3-19-91 \\
\text { Average }\end{array}$ & $\begin{array}{r}99 \\
104 \\
100 \\
103 \\
107 \\
99 \\
95 \\
86 \\
99\end{array}$ & $\begin{array}{l}91 \\
94 \\
91 \\
92 \\
91 \\
90 \\
89 \\
\frac{88}{91}\end{array}$ & $\begin{array}{r}8.4 \\
10.1 \\
9.4 \\
11.3 \\
16.2 \\
9.5 \\
6.5 \\
-2.3 \\
8.4\end{array}$ \\
\hline $\begin{array}{c}\text { St. Paul } \\
\text { Well } 1\end{array}$ & 30925 & $\begin{array}{r}8-16-90 \\
9-28-90 \\
11-16-90 \\
12-07-90 \\
1-19-91 \\
2-20-91 \\
3-21-91 \\
\text { Average }\end{array}$ & $\begin{array}{l}15 \\
16 \\
21 \\
20 \\
13 \\
13 \\
\frac{15}{16}\end{array}$ & $\begin{array}{l}13 \\
12 \\
14 \\
14 \\
15 \\
13 \\
14 \\
14\end{array}$ & \begin{tabular}{r|}
14.3 \\
28.8 \\
40.5 \\
35.7 \\
-14.3 \\
0.0 \\
6.9 \\
13.3
\end{tabular} \\
\hline
\end{tabular}


Table 5.--Pipefiow measurements made at public-supply facilities in Arkansas by noninvasive and inline flowmeter and notural log-percent difference-Continued

\begin{tabular}{|c|c|c|c|c|c|}
\hline $\begin{array}{l}\text { Facility } \\
\text { name }\end{array}$ & $\begin{array}{l}\text { Facility } \\
\text { ID } \\
\text { (fig. 1) }\end{array}$ & $\begin{array}{l}\text { Measure- } \\
\text { ment } \\
\text { date }\end{array}$ & $\begin{array}{l}\text { Pipeflow measured } \\
\text { by noninvasive } \\
\text { flowmeter } \\
\text { (a) } \\
\text { (gal } / \mathrm{min})\end{array}$ & $\begin{array}{c}\text { Pipeflow } \\
\text { measured by } \\
\text { inline flowmeter } \\
\text { (b) } \\
\text { (gal } / \mathrm{min})\end{array}$ & $\begin{array}{c}\begin{array}{c}\text { Natural } \\
\text { log-percent } \\
\text { difference }\end{array} \\
{[\ln (\mathbf{a} / \mathbf{b})]}\end{array}$ \\
\hline $\begin{array}{c}\text { St. Paul } \\
\text { Well } 2\end{array}$ & 30925 & $\begin{array}{r}7-16-90 \\
11-16-90 \\
12-07-90 \\
1-19-91 \\
2-20-91 \\
3-21-91 \\
\text { Average }\end{array}$ & $\begin{array}{l}15 \\
15 \\
15 \\
17 \\
15 \\
15 \\
15\end{array}$ & $\begin{array}{l}13 \\
13 \\
13 \\
- \\
- \\
\overline{13}\end{array}$ & $\begin{array}{c}14.3 \\
14.3 \\
14.3 \\
- \\
- \\
\overline{14.3}\end{array}$ \\
\hline Stamps & 30926 & $\begin{array}{r}6-18-90 \\
8-29-90 \\
9-19-90 \\
10-15-90 \\
11-26-90 \\
12-19-90 \\
1-23-91 \\
\text { Average }\end{array}$ & $\begin{array}{l}644 \\
599 \\
647 \\
645 \\
611 \\
647 \\
\frac{659}{636}\end{array}$ & $\begin{array}{l}630 \\
640 \\
630 \\
620 \\
625 \\
655 \\
\frac{650}{636}\end{array}$ & $\begin{array}{r}2.2 \\
-6.6 \\
2.7 \\
4.0 \\
-2.3 \\
-1.2 \\
\underline{1.4} \\
0.0\end{array}$ \\
\hline $\begin{array}{l}\text { Stuttgart } \\
\text { New Water } \\
\text { Treatment } \\
\text { Plant }\end{array}$ & 30932 & $\begin{array}{r}5-17-90 \\
6-22-90 \\
7-23-90 \\
8-27-90 \\
9-17-90 \\
10-17-90 \\
11-20-90 \\
12-21-90 \\
1-25-91 \\
2-25-91 \\
3-27-91 \\
\text { Average }\end{array}$ & $\begin{array}{r}- \\
1,294 \\
1,615 \\
1,358 \\
1,486 \\
1,632 \\
1,700 \\
1,483 \\
1,592 \\
1,659 \\
1, \overline{-}\end{array}$ & $\begin{array}{r}3,000 \\
3,000 \\
1,680 \\
3,648 \\
1,475 \\
1,650 \\
1,700 \\
1,450 \\
- \\
1,715 \\
1,700 \\
2,102\end{array}$ & $\begin{array}{c}- \\
-84.1 \\
-3.9 \\
-98.8 \\
.74 \\
-1.1 \\
0.0 \\
2.2 \\
- \\
-3.3 \\
-\overline{-31.4}\end{array}$ \\
\hline $\begin{array}{l}\text { Stuttgart } \\
\text { Old Water } \\
\text { Treatment } \\
\text { Plant }\end{array}$ & 30932 & $\begin{array}{r}5-17-90 \\
6-22-90 \\
7-23-90 \\
8-27-90 \\
9-17-90 \\
10-17-90 \\
11-20-90 \\
12-21-90 \\
1-26-91 \\
2-25-91 \\
3-27-91 \\
\text { Average }\end{array}$ & $\begin{array}{r}- \\
2,727 \\
1,957 \\
1,935 \\
1,767 \\
1,534 \\
1,805 \\
931 \\
1,757 \\
935 \\
984 \\
1,633\end{array}$ & $\begin{array}{r}2,200 \\
2,425 \\
1,760 \\
1,600 \\
1,750 \\
1,575 \\
1,800 \\
925 \\
1,790 \\
950 \\
\frac{975}{1,614}\end{array}$ & $\begin{array}{r}- \\
11.7 \\
10.6 \\
19.0 \\
1.0 \\
-2.6 \\
.3 \\
.6 \\
-1.9 \\
-1.6 \\
\frac{.9}{1.2}\end{array}$ \\
\hline
\end{tabular}


Table 5.--Pipeffow measurements made at public-supply facilities in Arkansas by noninvasive and inline flowmeter and natural log-percent difference-Continued

\begin{tabular}{|c|c|c|c|c|c|}
\hline $\begin{array}{l}\text { Facility } \\
\text { name }\end{array}$ & $\begin{array}{l}\text { Facility } \\
\text { ID } \\
\text { (fig. 1) }\end{array}$ & $\begin{array}{l}\text { Measure- } \\
\text { ment } \\
\text { date }\end{array}$ & $\begin{array}{l}\text { Pipeflow measured } \\
\text { by noninvasive } \\
\text { flowmeter } \\
(\mathrm{a}) \\
(\mathrm{gal} / \mathrm{min})\end{array}$ & $\begin{array}{c}\text { Pipeflow } \\
\text { measured by } \\
\text { inline flowmeter } \\
\text { (b) } \\
\text { (gal/min) }\end{array}$ & $\begin{array}{r}\begin{array}{c}\text { Natural } \\
\text { log-percent } \\
\text { difference }\end{array} \\
{[\ln (\mathrm{a} / \mathrm{b})]}\end{array}$ \\
\hline Thornton & 30945 & $\begin{array}{r}6-02-90 \\
8-24-90 \\
9-19-90 \\
10-16-90 \\
11-27-90 \\
12-20-90 \\
1-24-91 \\
\text { Average }\end{array}$ & $\begin{array}{l}114 \\
118 \\
115 \\
107 \\
111 \\
107 \\
106 \\
111\end{array}$ & $\begin{array}{r}110 \\
97 \\
100 \\
100 \\
100 \\
105 \\
\frac{110}{103}\end{array}$ & $\begin{array}{r}3.6 \\
19.6 \\
14.0 \\
6.8 \\
10.4 \\
1.9 \\
\frac{-3.7}{7.5}\end{array}$ \\
\hline Warren & 30970 & $\begin{array}{r}6-18-90 \\
10-18-90 \\
11-19-90 \\
12-20-90 \\
1-29-91 \\
2-26-91 \\
3-26-91 \\
\text { Average }\end{array}$ & $\begin{array}{r}1,650 \\
1,726 \\
1,733 \\
- \\
1,703 \\
2,096 \\
2,153 \\
1,844\end{array}$ & $\begin{array}{r}- \\
1,730 \\
1,730 \\
- \\
1,720 \\
2,145 \\
\underline{2,220} \\
1,909\end{array}$ & $\begin{array}{c}- \\
-0.2 \\
.2 \\
- \\
-1.0 \\
-2.3 \\
-3.1 \\
-3.5\end{array}$ \\
\hline Wright-Pastoria & 30999 & $\begin{array}{r}5-31-90 \\
8-22-90 \\
9-17-90 \\
10-11-90 \\
11-21-90 \\
12-18-90 \\
1-28-91 \\
\text { Average }\end{array}$ & $\begin{array}{l}179 \\
156 \\
180 \\
192 \\
188 \\
170 \\
\underline{185} \\
179\end{array}$ & $\begin{array}{l}185 \\
189 \\
188 \\
200 \\
185 \\
172 \\
182 \\
186\end{array}$ & $\begin{array}{r}-3.3 \\
-19.2 \\
-4.3 \\
-4.1 \\
1.6 \\
-1.2 \\
1.6 \\
-3.8\end{array}$ \\
\hline $\begin{array}{l}\text { Yorktown } \\
\text { Well } 1\end{array}$ & 31004 & $\begin{array}{r}1-28-91 \\
2-26-91 \\
3-28-91 \\
\text { Average }\end{array}$ & $\begin{array}{l}336 \\
311 \\
311 \\
319\end{array}$ & $\begin{array}{r}340 \\
340 \\
\overline{340}\end{array}$ & $\begin{array}{l}-1.2 \\
-8.9 \\
-6.4\end{array}$ \\
\hline $\begin{array}{l}\text { Yorktown } \\
\text { Well } 2\end{array}$ & 31004 & $\begin{array}{r}6-01-90 \\
7-30-90 \\
8-22-90 \\
9-18-90 \\
10-11-90 \\
11-30-90 \\
\text { Average }\end{array}$ & $\begin{array}{r}366 \\
360 \\
- \\
330 \\
369 \\
357 \\
356\end{array}$ & $\begin{array}{l}3 \overline{3} \\
310 \\
330 \\
360 \\
\frac{350}{341}\end{array}$ & $\begin{array}{l}\overline{2.0} \\
\overline{0} \\
0.0 \\
2.5 \\
\frac{2.0}{4.3}\end{array}$ \\
\hline
\end{tabular}


Table 5.--Pipeflow measurements made at public-supply facilities in Arkansas by noninvasive and Inline flowmeter and natural log-percent difference--Continued

\begin{tabular}{|c|c|c|c|c|c|}
\hline $\begin{array}{l}\text { Facility } \\
\text { name }\end{array}$ & $\begin{array}{l}\text { Facility } \\
\text { ID } \\
\text { (fig. 1) }\end{array}$ & $\begin{array}{c}\text { Measure- } \\
\text { ment } \\
\text { date }\end{array}$ & $\begin{array}{c}\text { Pipeflow measured } \\
\text { by noninvasive } \\
\text { flowmeter } \\
(\mathrm{a}) \\
(\mathrm{gal} / \mathrm{min})\end{array}$ & $\begin{array}{c}\text { Pipeflow } \\
\text { measured by } \\
\text { inline flowmeter } \\
\text { (b) } \\
\text { (gal } / \mathrm{min})\end{array}$ & $\begin{array}{l}\begin{array}{c}\text { Natural } \\
\text { log-percent } \\
\text { difference }\end{array} \\
{[\ln (a / b)]}\end{array}$ \\
\hline $\begin{array}{l}\text { Yorktown } \\
\text { Well } 3\end{array}$ & 31004 & $\begin{array}{r}5-31-90 \\
7-30-90 \\
8-22-90 \\
11-30-90 \\
12-17-90 \\
1-28-91 \\
2-26-91 \\
3-28-91 \\
\text { Average }\end{array}$ & $\begin{array}{r}- \\
287 \\
396 \\
295 \\
308 \\
308 \\
306 \\
305 \\
315\end{array}$ & $\begin{array}{l}315 \\
310 \\
405 \\
304 \\
307 \\
305 \\
304 \\
\underline{303} \\
319\end{array}$ & $\begin{array}{r}- \\
-7.7 \\
-2.2 \\
-3.1 \\
.3 \\
1.0 \\
.7 \\
-.7 \\
-1.3\end{array}$ \\
\hline $\begin{array}{l}\text { Yorktown } \\
\text { Well } 5\end{array}$ & 31004 & $\begin{array}{r}5-31-90 \\
6-01-90 \\
7-30-90 \\
8-22-90 \\
9-18-90 \\
10-11-90 \\
11-30-90 \\
12-17-90 \\
1-28-91 \\
2-26-91 \\
3-28-91 \\
\text { Average }\end{array}$ & $\begin{array}{r}-\overline{3} \\
- \\
- \\
314 \\
320 \\
330 \\
327 \\
317 \\
306 \\
311 \\
319\end{array}$ & $\begin{array}{r}315 \\
- \\
310 \\
405 \\
- \\
- \\
304 \\
307 \\
305 \\
304 \\
303 \\
319\end{array}$ & $\begin{array}{l}- \\
\overline{-} \\
\overline{-} \\
- \\
\overline{-} \\
8.2 \\
6.3 \\
3.9 \\
.7 \\
2.6 \\
0.0\end{array}$ \\
\hline
\end{tabular}


Table 6.--Absolute average percent differences between water use measured by noninvasive flowmeter and that reported to the Arkansas Soil and Water Conservation Commission (ASWCC), the Arkansas Department of Health (ADH), and measured by inline flowmeter for facillties serving population less than 500, 500-900, $901-3,000$, and more than 3,000

(ID, identification number; <, less than; >, greater than; - no measurement)

\begin{tabular}{|c|c|c|c|c|c|}
\hline $\begin{array}{l}\text { Range in } \\
\text { population }\end{array}$ & Facility name & $\begin{array}{l}\text { Facility } \\
\text { ID } \\
\text { (fig. 1) }\end{array}$ & $\begin{array}{l}\text { Reported to } \\
\text { ASWCC }\end{array}$ & $\begin{array}{l}\text { Reported to } \\
\text { ADH }\end{array}$ & $\begin{array}{l}\text { Measured by } \\
\text { inline flowmeter }\end{array}$ \\
\hline \multirow{11}{*}{$<500$} & Bennett Acres & 30543 & 23.6 & - & -- \\
\hline & Big Flat & 30550 & 2.4 & 2.5 & 45.0 \\
\hline & Cass & 30584 & - & 25.4 & - \\
\hline & Collins & 30596 & 6.0 & 5.4 & 2.0 \\
\hline & Franklin & 30666 & 18.3 & - & 14.9 \\
\hline & Guy & 30693 & 21.4 & - & 38.9 \\
\hline & Harrell & 30699 & 30.2 & - & 18.4 \\
\hline & Roe & 30894 & 34.0 & - & 4.5 \\
\hline & Sidney & 30916 & 16.6 & - & 26.2 \\
\hline & St. Paul - Well 1 & 30925 & 15.2 & 13.0 & 15.4 \\
\hline & & Average & $\overline{18.6}$ & $\overline{11.6}$ & $\overline{20.7}$ \\
\hline \multirow[t]{12}{*}{$500-900$} & Arkansas City & 30523 & 35.4 & - & - \\
\hline & Bergman & 30547 & 10.1 & - & 5.5 \\
\hline & Bigelow & 30551 & 28.9 & - & 23.6 \\
\hline & Carthage & 30582 & 26.6 & - & 46.4 \\
\hline & Gilmore & 30676 & 77.7 & - & 9.3 \\
\hline & Holly Grove & 30713 & 9.4 & 15.9 & 3.4 \\
\hline & Ogden - Well 1 & 30836 & 66.8 & - & 41.4 \\
\hline & Ogden - Well 2 & 30836 & 46.9 & - & 37.5 \\
\hline & Oxford & 30843 & 9.1 & 20.3 & 17.6 \\
\hline & Russell & 30896 & - & - & - \\
\hline & Thornton & 30945 & 18.2 & $=$ & $\underline{4.9}$ \\
\hline & & Average & 32.9 & $\overline{18.1}$ & 21.1 \\
\hline \multirow[t]{12}{*}{$901-3,000$} & Black Rock & 30556 & 23.9 & - & - \\
\hline & Calico Rock & 30576 & 36.9 & - & - \\
\hline & Dierks & 30631 & 83.7 & 49.4 & - \\
\hline & Haskell & 30702 & 9.8 & - & 4.3 \\
\hline & Hoxie & 30719 & 4.1 & 4.7 & - \\
\hline & Huntsville & 30723 & - & 7.2 & 2.1 \\
\hline & Norphlet - Well 1 & 30830 & - & - & 13.4 \\
\hline & Norphlet - Wells 1,2 & 30830 & 20.0 & - & - \\
\hline & Parkin & 30852 & 14.3 & - & - \\
\hline & Stamps & 30926 & 5.4 & - & 2.6 \\
\hline & Wright-Pastoria & 30999 & 6.2 & 6.2 & 7.4 \\
\hline & & Average & $\overline{22.7}$ & $\overline{16.9}$ & $\overline{5.9}$ \\
\hline
\end{tabular}


Table 6.--Absolute average percent differences between water use measured by noninvasive flowmeter and that reported to the Arkansas Soll and Water Conservation Commlssion (ASWCC), the Arkansas Department of Health (ADH), and measured by inllne flowmeter for facllities serving population less than 500, 500-900,901-3,000, and more than 3,000-Continued

\begin{tabular}{lllccc}
\hline $\begin{array}{l}\text { Range in } \\
\text { population }\end{array}$ & Facility name & $\begin{array}{c}\text { Facility } \\
\text { ID } \\
\text { (fig. 1) }\end{array}$ & $\begin{array}{c}\text { Reported to } \\
\text { ASWCC }\end{array}$ & $\begin{array}{c}\text { Reported to } \\
\text { ADH }\end{array}$ & $\begin{array}{c}\text { Measured by } \\
\text { inline flowmeter }\end{array}$ \\
\hline$>3,000$ & 20600 & 34.8 & 33.4 & 4.9 \\
& Camden & 30686 & 8.2 & 8.3 & - \\
& Green Forest & 30778 & - & 28.9 & - \\
& Marianna & 30812 & 19.6 & 19.4 & 6.3 \\
& Mountain Home & 30859 & 29.5 & 29.5 & - \\
& Perryville & 30871 & 13.8 & 23.5 & - \\
& Prairie Grove & 30932 & 35.5 & - & - \\
& Stuttgart - total & 17.3 & 18.5 & - \\
& Trumann - Wells 1,2 & 30950 & 2.8 & 3.8 & - \\
& Trumann - City Hall & 30950 & 39.8 & 40.9 & - \\
& Trumann - Davis St. & 30950 & 30969 & - & 3.0 \\
& Ward - Well 2 & 30960.0 & 5.2 \\
& Ward - Well 4 & 30960 & 3.4 & - & 14.2 \\
& Warren - Wells 1,2 & 30970 & 19.0 & - & 3.1 \\
& Warren - Well 3 & 30970 & - & - & 8.8 \\
\hline
\end{tabular}


Table 7.--Percent difference between water use reported to the Arkansas Soll and Water Conservation Commission (ASWCC) and measured by inline flowmeter

\begin{tabular}{|c|c|c|c|c|c|}
\hline Facility name & $\begin{array}{c}\text { Facility } \\
\text { ID } \\
\text { (fig. 1) }\end{array}$ & $\begin{array}{l}\text { Period of } \\
\text { record }\end{array}$ & $\begin{array}{c}\text { Water use } \\
\text { reported to } \\
\text { the ASWCC } \\
\text { a } \\
\text { (gallons) }\end{array}$ & $\begin{array}{c}\text { Water-use } \\
\text { measured by } \\
\text { inline flowmeter } \\
\mathrm{b} \\
\text { (gallons) }\end{array}$ & $\begin{array}{r}\text { Percent } \\
\text { difference } \\
{[(a-b) / b] \times 100}\end{array}$ \\
\hline Bergman & 30547 & $8 / 90-2 / 91$ & $10,259,222$ & $10,623,807$ & -3.4 \\
\hline Bigelow & 30551 & $6 / 90-1 / 91$ & $11,736,500$ & $12,109,239$ & -3.1 \\
\hline Big Flat & 30550 & $5 / 90-12 / 90$ & $4,503,261$ & $3,570,692$ & 26.1 \\
\hline Camden & 20600 & $5 / 90-4 / 91$ & $326,097,800$ & $486,646,900$ & -33.0 \\
\hline Carthage & 30582 & $5 / 90-3 / 91$ & $23,551,000$ & $23,905,548$ & -1.5 \\
\hline Collins & 30596 & $8 / 90-2 / 91$ & $2,711,081$ & $2,663,673$ & 1.8 \\
\hline Franklin & 30666 & $8 / 90-2 / 91$ & $3,401,200$ & $3,610,141$ & -5.8 \\
\hline Gilmore & 30676 & $6 / 90-3 / 91$ & $11,029,030$ & $7,951,800$ & 38.7 \\
\hline Guy & 30693 & $8 / 90-2 / 91$ & $9,421,532$ & $9,668,528$ & -2.6 \\
\hline Harrell & 30699 & $7 / 90-2 / 91$ & $7,020,000$ & $5,914,925$ & 18.7 \\
\hline Haskell & 30702 & $6 / 90-12 / 90$ & $26,338,536$ & $28,494,541$ & -7.6 \\
\hline Holly Grove & 30713 & $6 / 90-12 / 90$ & $41,611,172$ & $43,079,394$ & -3.4 \\
\hline Ogden - Well 1 & 30836 & $6 / 90-2 / 91$ & $7,294,284$ & $15,931,232$ & -54.2 \\
\hline Ogden - Well 2 & 30836 & $6 / 90-2 / 91$ & $4,052,027$ & $4,778,106$ & -15.2 \\
\hline Oxford & 30843 & $6 / 90-5 / 91$ & $3,896,000$ & $4,103,103$ & -5.0 \\
\hline Perryville & 30859 & $6 / 90-12 / 90$ & $85,490,267$ & $76,964,413$ & 11.1 \\
\hline Roe & 30894 & $6 / 90-2 / 91$ & $3,390,010$ & $6,020,333$ & -43.7 \\
\hline Sidney & 30916 & $6 / 90-2 / 91$ & $13,320,000$ & $16,110,308$ & -17.3 \\
\hline St. Paul & 30925 & $8 / 90-2 / 91$ & 760,400 & 785,674 & -3.2 \\
\hline Stamps & 30926 & $6 / 90-12 / 90$ & $93,574,000$ & $97,215,640$ & -3.7 \\
\hline Stuttgart - new & 30932 & $7 / 90-1 / 91$ & $326,476,634$ & $245,784,490$ & 32.8 \\
\hline Stuttgart - old & 30932 & $6 / 90-3 / 91$ & $464,246,436$ & $339,176,340$ & 36.9 \\
\hline Thornton & 30945 & $6 / 90-12 / 90$ & $9,914,562$ & $12,234,285$ & -19.0 \\
\hline Wright-Pastoria & 30999 & $5 / 90-12 / 90$ & $16,204,620$ & $15,641,282$ & 3.6 \\
\hline Yorktown - Well 3 & 31004 & $5 / 90-4 / 91$ & $26,397,497$ & $68,144,517$ & -61.3 \\
\hline Yorktown - Well 5 & 31004 & $5 / 90-4 / 91$ & $30,696,243$ & $29,635,408$ & 3.6 \\
\hline
\end{tabular}




\section{Table 8.--Percent difference between water use reported to the Arkansas Soll and Water}

Conservation Commlssion (ASWCC) and the Arkansas Department of Health (ADH)

\begin{tabular}{|c|c|c|c|c|c|}
\hline Facility name & $\begin{array}{l}\text { Facility } \\
\text { ID } \\
\text { (fig. 1) }\end{array}$ & $\begin{array}{c}\text { Period of } \\
\text { record }\end{array}$ & $\begin{array}{l}\text { Water use } \\
\text { reported to } \\
\text { ASWCC } \\
\text { (a) } \\
\text { (gallons) }\end{array}$ & $\begin{array}{l}\text { Water use } \\
\text { reported to } \\
\text { ADH } \\
\text { (b) } \\
\text { (gallons) }\end{array}$ & $\begin{array}{c}\text { Percent } \\
\text { difference } \\
{[(a-b) / b] \times 100}\end{array}$ \\
\hline Big Flat & 30550 & $5 / 90-12 / 90$ & $5,901,162$ & $5,920,500$ & -0.3 \\
\hline Camden & 20600 & $5 / 90-4 / 91$ & $682,147,560$ & $682,717,000$ & -.1 \\
\hline Collins & 30596 & $8 / 90-2 / 91$ & $2,711,081$ & $2,712,000$ & -.0 \\
\hline Dierks & 30631 & $5 / 90-2 / 91$ & $15,517,025$ & $47,717,000$ & -67.5 \\
\hline Green Forest & 30686 & $8 / 90-2 / 91$ & $187,506,271$ & $187,352,500$ & .1 \\
\hline Holly Grove & 30713 & $6 / 90-12 / 90$ & $41,611,172$ & $37,409,000$ & 11.2 \\
\hline Hoxie & 30719 & $6 / 90-2 / 91$ & $17,708,832$ & $16,419,000$ & 7.9 \\
\hline Mountain Home & 30812 & $7 / 90-2 / 91$ & $395,494,006$ & $366,997,000$ & 7.8 \\
\hline Perryville & 30859 & $6 / 90-12 / 90$ & $85,490,267$ & $85,506,000$ & -.0 \\
\hline Prairie Grove & 30871 & $6 / 90-1 / 91$ & $65,884,600$ & $62,747,000$ & 5.0 \\
\hline St. Paul - Well 1 & 30925 & $8 / 90-2 / 91$ & 760,400 & 848,000 & -10.3 \\
\hline St. Paul - Well 2 & 30925 & $12 / 90-2 / 91$ & 192,500 & 251,900 & -23.6 \\
\hline Trumann - Wells 1,2 & 30950 & $6 / 90-2 / 91$ & $345,977,690$ & $344,863,000$ & .3 \\
\hline Trumann - City Hall well & 30950 & $6 / 90-2-91$ & $172,988,845$ & $172,281,500$ & .4 \\
\hline Trumann - Davis St. well & 30950 & $6 / 90-2-91$ & $172,988,845$ & $172,281,500$ & .4 \\
\hline Warren - Wells 1,2 & 30970 & $5 / 90-2 / 91$ & $262,609,611$ & $280,748,800$ & -6.5 \\
\hline Wright-Pastoria & 30999 & $5 / 90-12 / 90$ & $18,472,543$ & $18,473,700$ & -.0 \\
\hline
\end{tabular}

